\title{
PALEOSEISMICITY OF THE COOK INLET REGION, ALASKA: EVIDENCE FROM PEAT STRATIGRAPHY IN TURNAGAIN AND KNIK ARMS
}

By R.A. Combellick

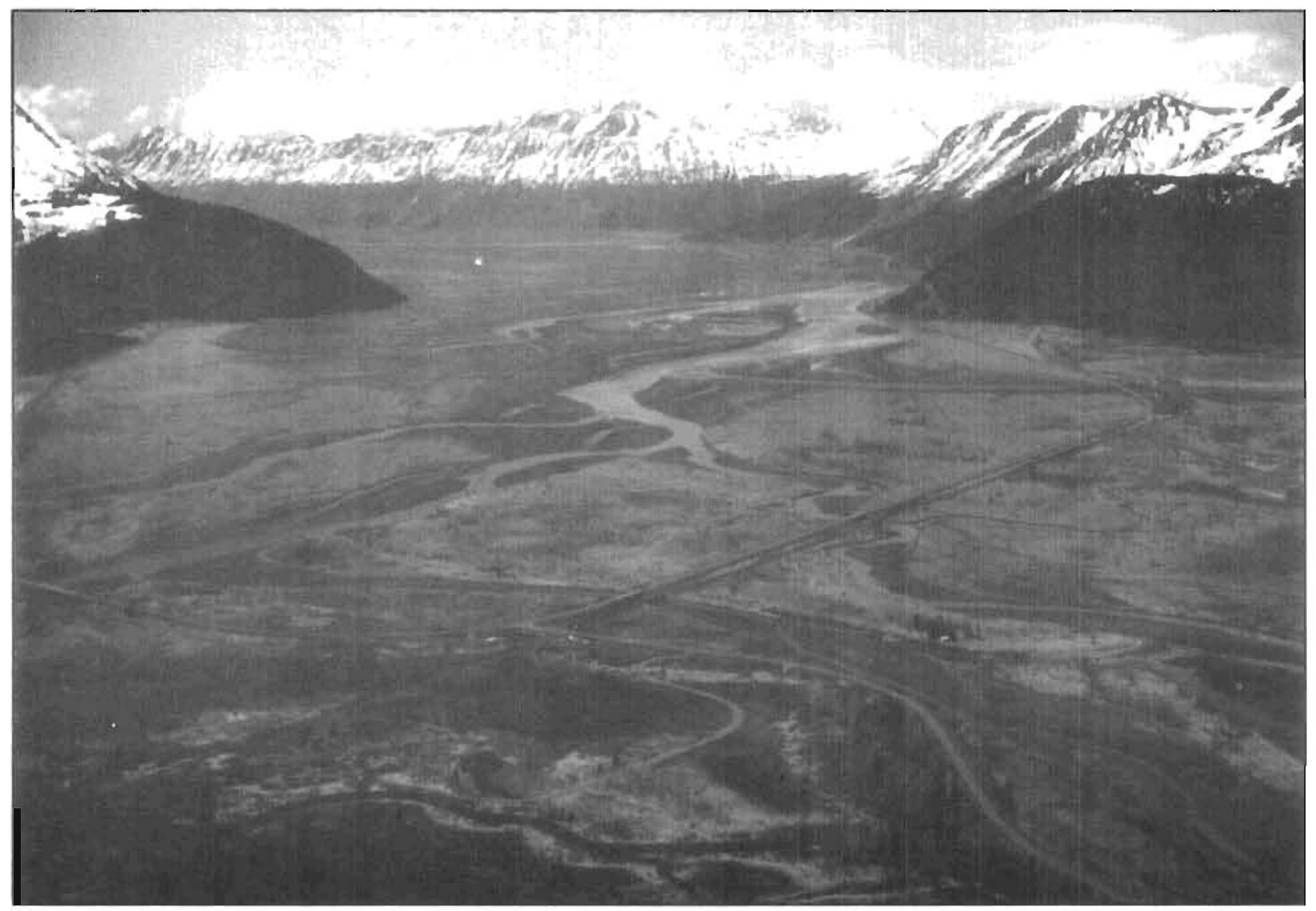

Professional Report 112

Published by

STATE OF ALASKA

DEPARTMENT OF NATURAL RESOURCES

DIVISION OF GEOLOGICAL \& GEOPHYSICAL SURVEYS 


\section{PALEOSEISMICITY OF THE COOK INLET REGION, ALASKA: EVIDENCE FROM PEAT STRATIGRAPHY IN TURNAGAIN AND KNIK ARMS}

By R.A. Combellick

Division of Geological \& Geophysical Surveys

Professional Report 112 


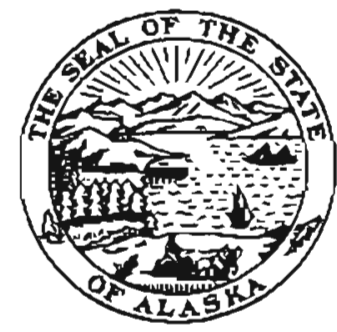

STATE OF ALASKA

Walter J. Hickel, Governor

DEPARTMENT OF NATURAL RESOURCES

Harold C. Heinze, Commissioner

DIVISION OF GEOLOGICAL \& GEOPHYSICAL SURVEYS

Thomas E. Smith, Direcror and State Geologist

DGGS publications may be inspected at the following locations.

Alaska Division of Geological \& Geophysical Surveys

794 University Aveaue, Suite 200

Fairbanks, Alaska 99709-3645

400 Willoughby Avenue, 3rd floor

Juneau, Alaska 99801-1796

U.S. Geological Survey Earth Science Information Center

605 West 4th Avenue, Room G684

4230 University Drive, Room 101

Anchorage, Alaska 99501-2299

Anchorage, Alaska 99508-4664

Address mail orders to the Fairbanks office.

This publication, released by the Division of Geological \& Geoplysical Surveys, was produced and printed in Fairbanks, Alaska, at a cost of $\$ 5.00$ per copy. Publication is required by Alaska Statute 41 , "to determine the potential of Alaskan land for production of metals, minerals, fuels, and geothermal resources; the location and supplies of groundwater and construction materials; the potential geolngic hazards to buildings, roads, bridges, aud of her installations and structures; and shall cooduct such other surveys and in vestigations as will advance knowledge of the geology of Alask $\theta_{\text {." }}$

Cover: Ponage area, Seward Highway, and upper Turnagain Arm in 1984, Looking northwest. The great Alaska earihquake of 1964 caused this area to subside about $7.9 \mathrm{f}(2.4 \mathrm{~m})$. Extensive tital flooding resulted. 


\section{CONTENTS}

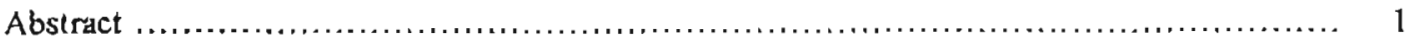

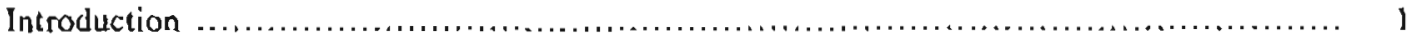

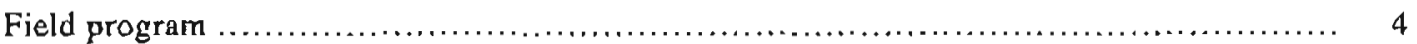

Equipment and logistics ...........................................................

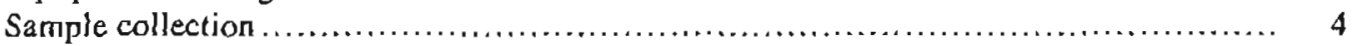

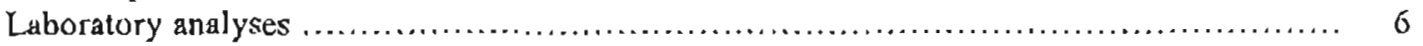

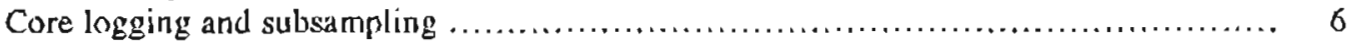

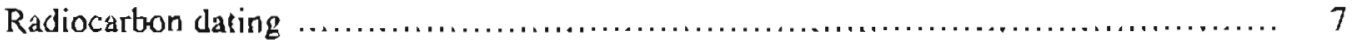

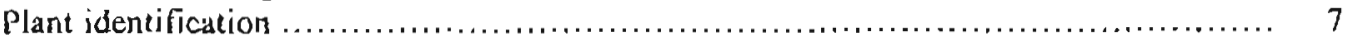

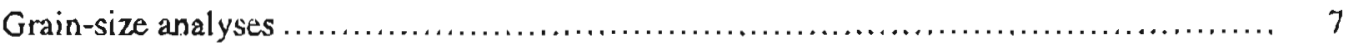

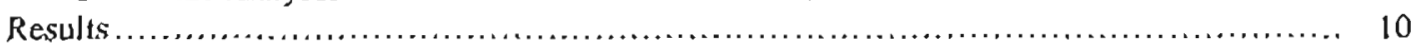

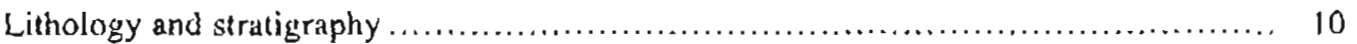

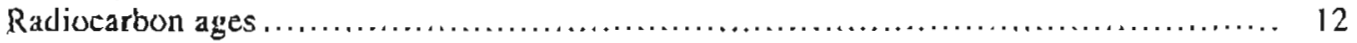

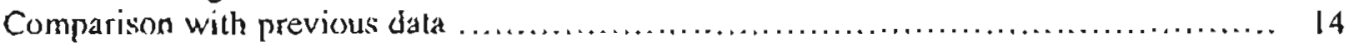

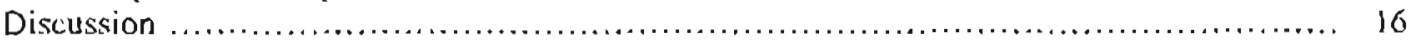

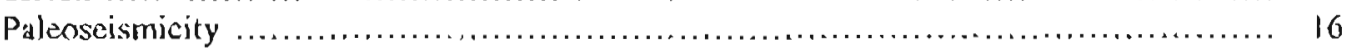

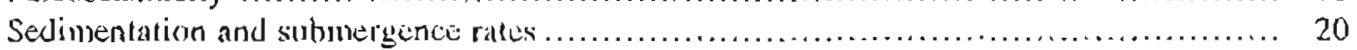

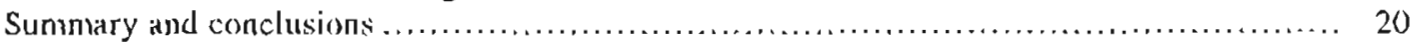

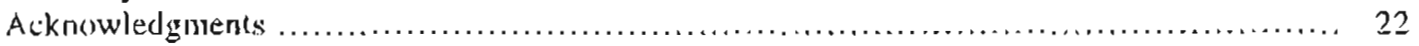

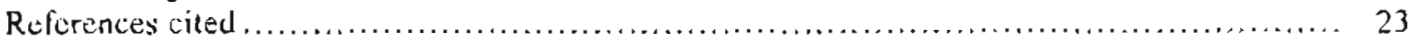

Appendix A - Descriptions of core samples ........................................... 25

Appendix B - Grain-size analyses ................................................. 45

FIGURES

Figure 1. Map of tectonic deformation associated with the great Alaska

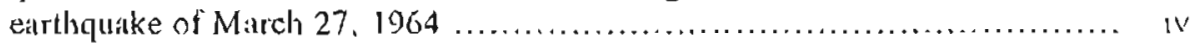

2. Aerial photesgraph of the Porlage areat, upper T'urnagain Arm .................. 2

3. Photograph of pre-1964 vegetation and peat buried as a rusult of submergence during the great Alaska earrhejuake ......................... 3

4. Locition map of region near Anchorage, Alaska ............................. 5

5. Photograph of burehole drilling near Goose Bay ............................. 6

6. Cross section of hollow-stem auger and continuous-sampling system ............ 7

7. Lithologic logs of boreholes drilled in 1988 and 1989 in upper Tumagain and Knik Arms .......................................... 11

8. Photographs of buried peat layers in boreholes TAl and TA8 at Portage ........ 13

9. Plots of age versus depth for six boreholes in upper Turnagain and Knik Arms ....................................................... 15

10. Comparison between radiocarbon ages of samples from boreholes drilled at adjacene locations near Girdwood and Porlage in 1985 and 1988 .......... 17

11. Reported radiocarbon ages of submerged peats and uplifted terraces in the region of the 1964 greal Alaska earilhquake

B-I through B-9. Litbologic logs and plots of grain-size analyses for nine boreholes

\section{'TABLES}

Table 1. Radiccarbon ages of samples from boreholes drilled near Girdwood and Portage in 1985

2. Radiocarbon ages of samples from boreholes drilled in vicinity of

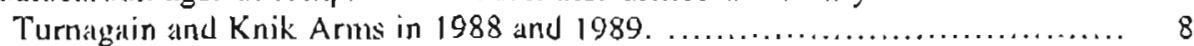

3. Ielentification of plant fragnents in buried peats and organic-rich layers ........... 9

B-1. Grain-size analyses ...................................................... 45 


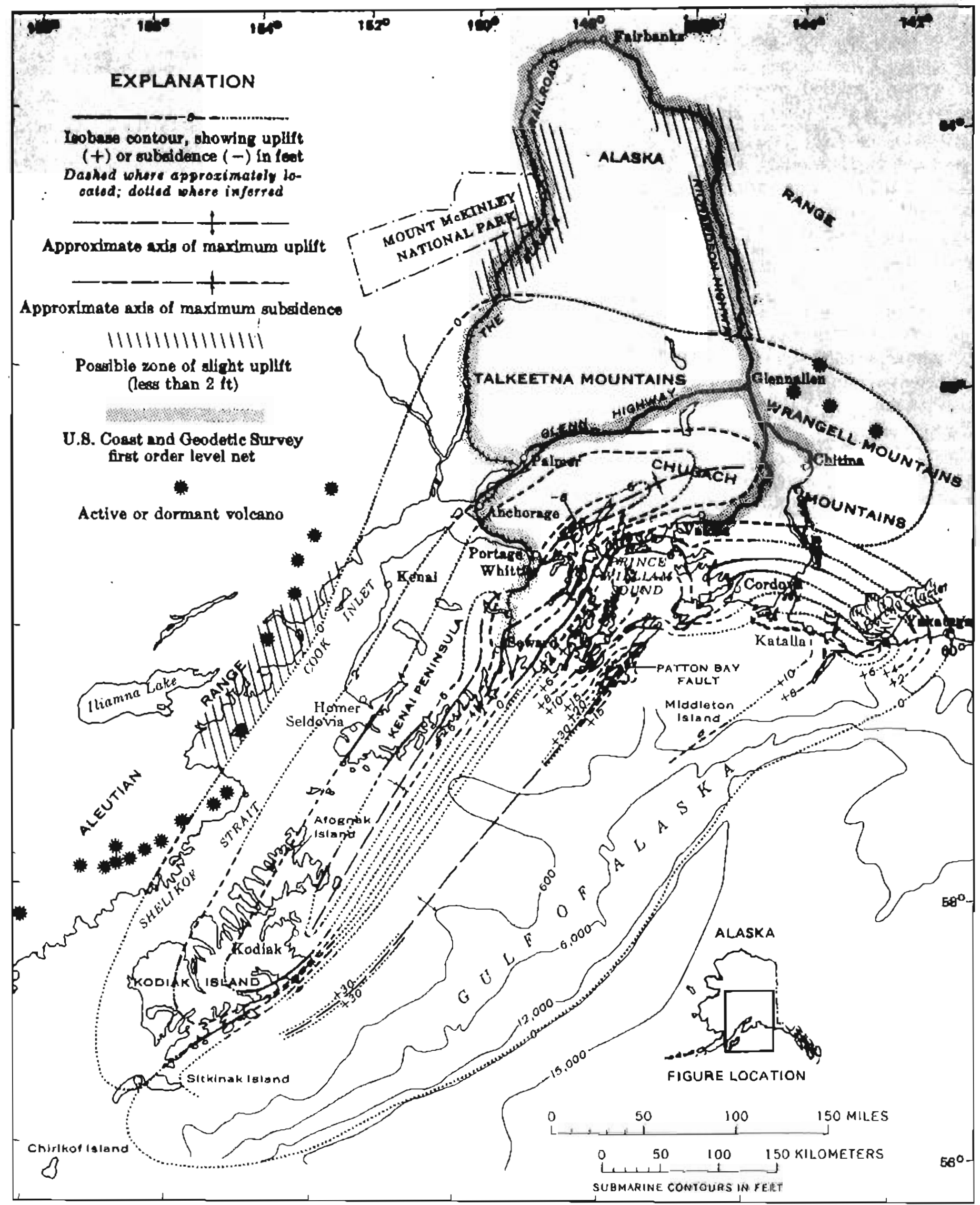

Figure 1. Tectonic deformation associaled with she greas Alaska earihquake of March 27, 1964 (modified from Plafker, 1969). 


\title{
PALEOSEISMICITY OF THE COOK INLET REGION, ALASKA: EVIDENCE FROM PEAT STRATIGRAPHY IN TURNAGAIN AND KNIK ARMS
}

\author{
By \\ R.A. Combellick \\ Alaska Division of Geological \& Geophysical Surveys
}

\section{ABSTRACT}

A record of prehistoric subsidenoc events, possibly associated with 1964-style major carthquakes, is preserved in estuarine sodiments of upper Cook Inlet. Borchole drilling and continuous sampling at ninc locations in Turnagain and Knik Arms confirm that multiple pcat layers were submerged below present high-tide level and buried by intertidal silt and clay during repeated subsidence cvents. The-resulting peat-silt couplets provide a record of repeated supratidal vegetation growth, subsidence, and rapid burial. Radiocarbon dating of these peat layers provides maximum ages of the subsidence cvents that caused burial of the peats and allows calculation of long-term submergence rates. Although none of the borchole samples exhibit conclusive evidence that mujor ground shsking accompanied peat submergenec and burial, repeated sudden tectonic lowering was the most likely mechanism for producing the obscrved peat-silt stratigraphy.

Bocause of uncertainties in some of the radiocarbon-age data and incomplete corrclations with data from other studies in the region, it is not yet possible to construct a reliable regional chronology of events. However, the number of buried peats suggests a minimum of six to eight subsidence events during the pasl 4,200 radiocarbon yr. This translates to a maximum avcrage recurrence interval of aboul 525 to 700 yr (590 10 780 yr for about the past 4,700 caiendar yr, if calculated on the basis of trec-ring calibrated ages). In upper Turnagain Arm, threc buried peat layers that date to within 100 yr of each other suggest that recurrence intervals may have been as short as several decades. At five locations in both Tumagain and Krik Arms, radiacarbon ages of shallow peat layers suggest that the most recent major subsidence cvent prior to the 1964 earhquake was at or before about 500 y.a. The data indicate net submergence rates of $0.23100 .30 \mathrm{~cm} / \mathrm{yr}$ in upper Turnagain A rm lor the past 4,200 radiocarbon ys and 0.13 to $0.17 \mathrm{~cm} / \mathrm{yr}$ in upper Xnik Arm for the past 2,100 radiocarbon yr.

\section{INTRODUCTION}

Following the catastrophic great Alaska earthquake of March 27, 1964, geoscientists began to address the question of how soon another damaging earthquake is likely to strike this area of southcentral Alaska, home to nearly 60 percent of the state's 500,000 residents. Seismic monitoring of smaller events has allowed detailed mapping of the Benioff zone and megathrusl-interplate boundary and has improved estimates of earthquakerecurrence intervals based on analyses of slip rates and strain release. However, recurrence estimates of great earthquakes based on these historic data must be regarded as tentative because the instrumental record extends back only to about the turn of the century, and the 1964 event is the only known great earthquake in this segment of the Aleutian megathrust during historic time. A reliable geologic record of major prehistoric subduction-zone earthquakes in this region for the past several thousand years would complement the historic record and would greatly improve the credibility of recurrence estimates. A chronology of these events would also provide a measure of variability from the average recurrence interval.

The 1964 earthquake caused vertical ground displacements over a $100,000-\mathrm{mi}^{2}\left(260,000-\mathrm{km}^{2}\right)$ area' (fig. 1). This vertical deformation consisted of an asymmetric uplift zone parallel to the arc and an adjacent landward zone of subsidence (Plafker, 1969). Geologic evidence indicates that similar deformation occurred during the late Holocene, or past 5,000 yr. A total of $131 \mathrm{f}(40 \mathrm{~m})$ of uplift occurred at Middleton Island (fig. 1) during at least five distinct uplift pulses during the last 4,470 yr, based on radiocarbon ages of driftwood and peat on marine uplifted terraces (Plafker and Rubin, 1967). This record represents a linear uplift rate of about $1 \mathrm{~cm} / \mathrm{yr}$. A terrace is now forming on Miduleton Island due to $10.8 \mathrm{ft}(3.3 \mathrm{~m})$ of 1964 uplift. Based on the known ages of uplifted terraces, the recurrence interval for megathrust earthquakes like the 1964 earthquake is 500 to 1,350 yr (Plafker and Rubin, 1967).

Knik and Turnagain Arms, located at the northeastern limit of Cook Inlet in the subsidence zone of the 1964 earthquake (fig. 1), are likely basins in which to find sedimentary evidence of subsidence events associated with major earthquakes. Based on post-1964 survey data,

\footnotetext{
'In this report, most measurements are reported in English units followed by melric conversions in parcniheses. English units wero used because measurement of sample deputh in feel was more convenient with the drilling and sampling equip ment available for this project. Howeves, the results of certain calculations like sedimentation rates are reported in metric units for esse of comparison with similar results reported in the lineralure.
} 


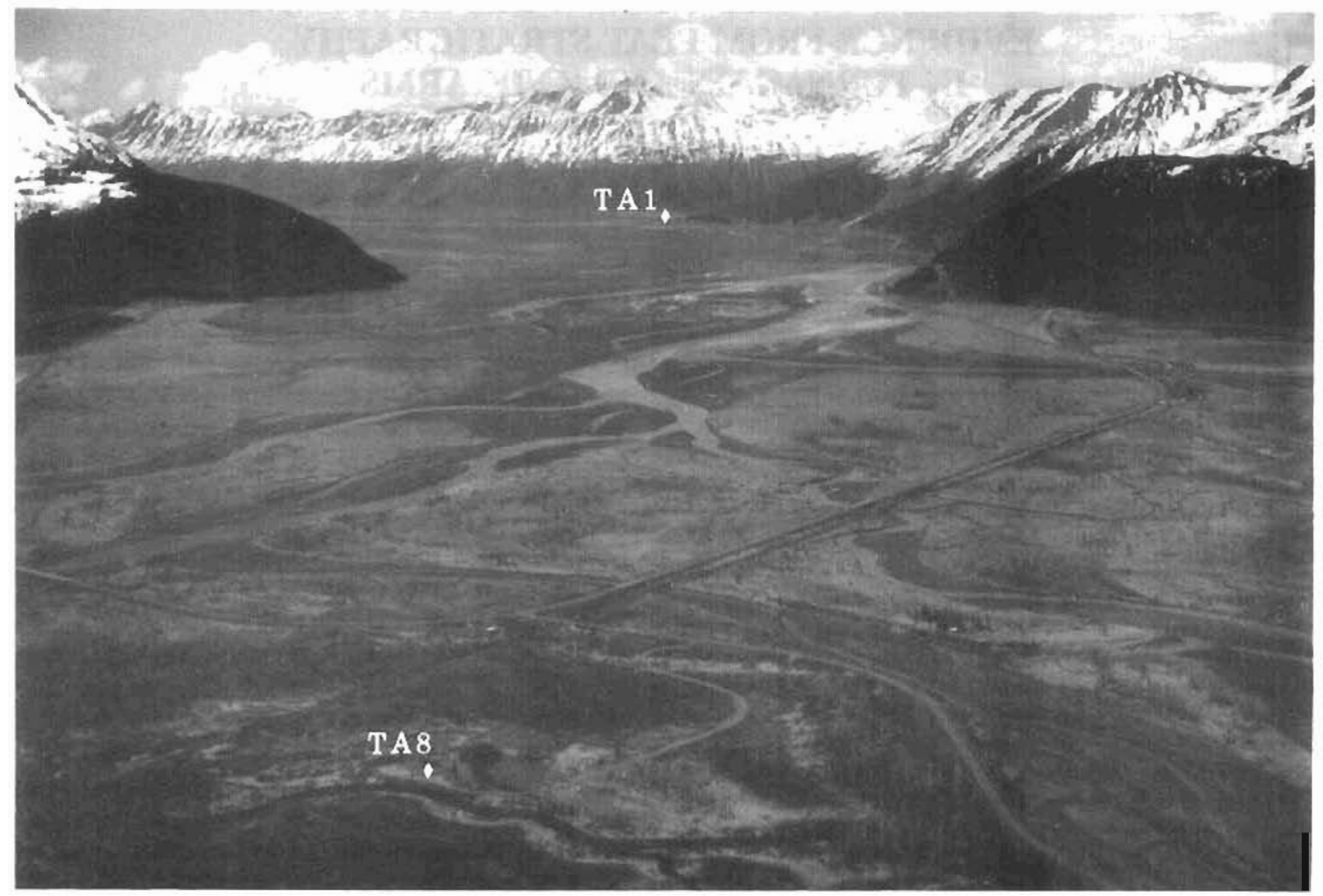

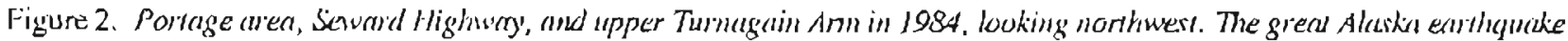

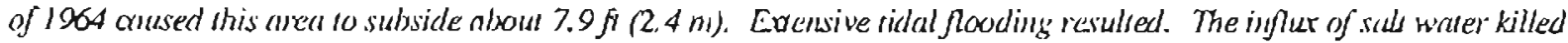
maxt rees shown in line cenwal pary of he phologmph and cuused rupid deposition of sill on the submerged flat. Sill depasitian

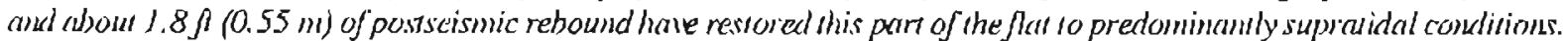
Loccuions of boreholes as Ginduoad (TAI) and Portage (TA8) are idenrified in the photo.

the Knik Arm tidal flacs subsided al least 2 ft $(0.6 \mathrm{~m})$ during the 1964 Alaska earthquake (Foster and Karlsirom, 1967: Plafker. 1969). Subsidence was due to lectonic lowering of the crust and to compaction of unconsotidated materials undemeath the tidal tlats, Extensive tidal flooding resulted, depositing intertidal silts over lhe 1964 soil horizon in al least the southwestem half ol the fats.

A similar post-1964 cycle (subsidence, saltwater incursion, vegetation kill, intertidal deposition, and revegulation) has been documented for the upper part of Tumagain Arm southeast of Anchorage (Ovenshine and (shcrs, 1976; fig. 2). This cycle for upper Tumagain Arm has restored the sedinient surface to its pre-earlhquike level (Kachadorian and Ovenshine, 1984; BarlschWinkler and Garrow, 1982). In 1964, this region subsided about $7.9 \mathrm{fl}(2.4 \mathrm{~m})$, allhough as much as $1.8 \mathrm{ft}$
$(0.55 \mathrm{~m})$ of rebound uccurred following the earihquake (Brown and others, 1977). Abolt $5.2 \mathrm{ft}$ (1.6 m) of intertidal silt has accumulated on the 1964 soil horizon (fig. 3), which is about the expected anount of deposituon for the net subsidence of the region.

In 1985, borehole drilling at Iwo Tumagain Arm sites, one at Girdwond and one at Portage, Lonfirned the presence of multiple organic layer's interbedded with tidal deposits below the 1964 soil horizon. Organic layers (peat or organic silı) are each overlain by 2 to 10 fi $(0.6103 \mathrm{~m})$ of finc silty sand, sandy silt, and clayey silt. Many peat layers have sharp upper contacts and are overlain by organic-poor intertidal sediments. This stratigraphy is inlerpreted to represent episodic prehistoric subsidence in Turnagain Arns similar to that resulting from the 1964 great earthcuake (Combellick, 1986). Atwater (1987) interpreted sinilar stratigmaphy of estuarine deposits in 


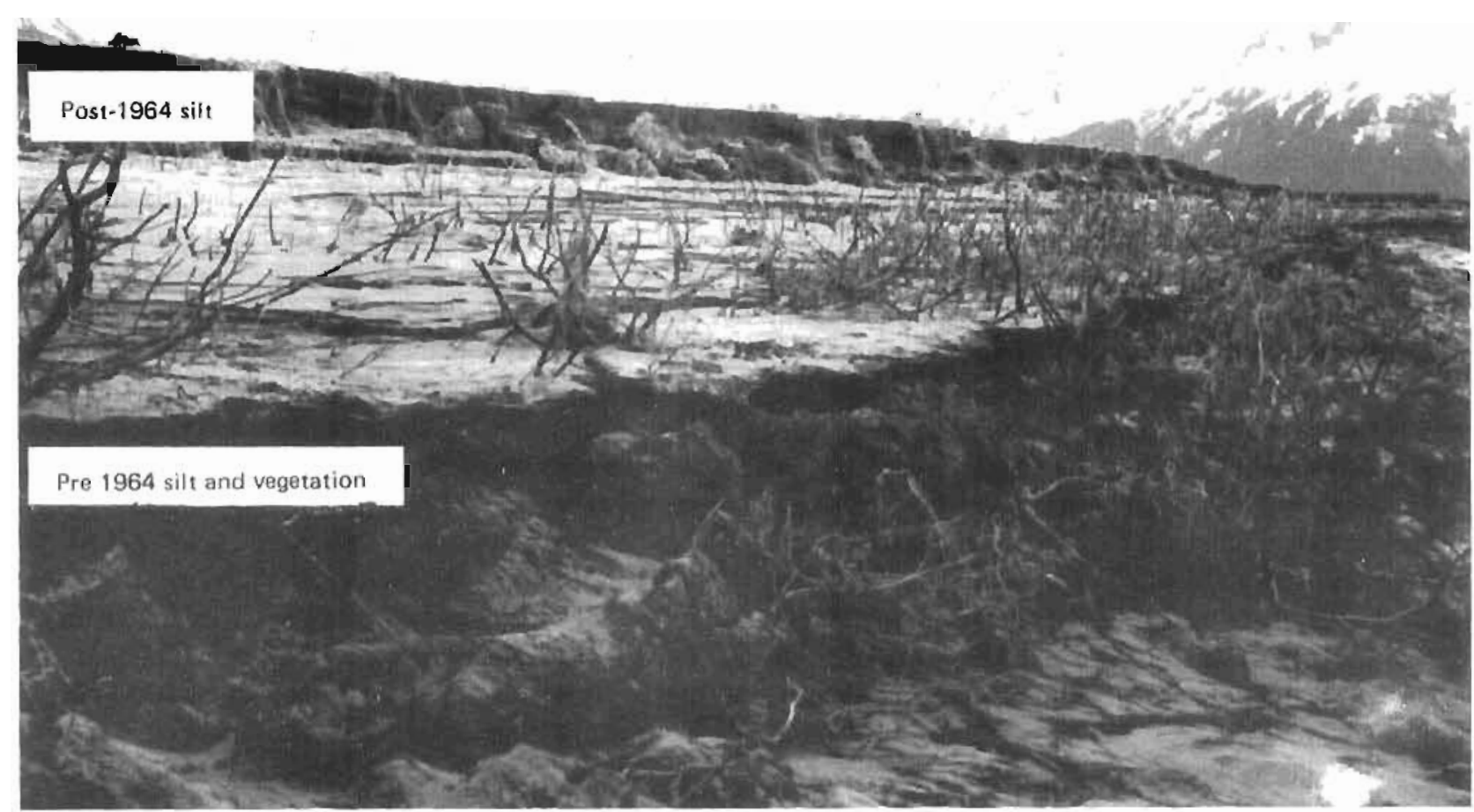

Figure 3. Vegetmion and pent layer submerged during the great Alaska earthquake of 1964 and huried beneath approximniciy $5.2 \mathrm{fl}(1.6 \mathrm{~m})$ of post-1964 intridal silh. Part of the overlying sill layer has been removed by erosion. Erpoxure is in a sidal chnmel near Girdwood in upper Turnagain Amm (198t phorograph).

Table 1. Radiocarbon ages of samples from wo borcholes drilled near Girdwood (TA-BI) and Porlage (TA-B8) in upper Turnagain Arn in 1985

\begin{tabular}{|c|c|c|c|c|c|}
\hline Barchale & Sample depth & $\begin{array}{c}\text { Laboralory } \\
\text { number }\end{array}$ & Material daled & $\begin{array}{l}\text { Radiocarbon } \\
\text { agc (yr B.P.) }\end{array}$ & $\begin{array}{l}\text { Calibraced } 1 \sigma \text { age } \\
\text { rangc (yr B.P.) }\end{array}$ \\
\hline TA-B! & $10.0 \cap(3.05 \mathrm{~m})$ & $G X-11346$ & Scdyc par & $1,935 \pm 150$ & $1,710-2,059$ \\
\hline TA-BI & $20.0 \mathrm{a}(6.10 \mathrm{~m})$ & $G \times-11347$ & Wood-sedge peat & $2.735 \pm 145$ & $2,749-2,989$ \\
\hline TA-BI & $23.0 \cap(6.71 \mathrm{~m})$ & GX-11348 & Wood-sedge peat & $2,660 \pm 100$ & $2,739-2,859$ \\
\hline TA-BI & $25.5 \mathrm{n}(7.77 \mathrm{~m})$ & $6 X-11349$ & Wood-sedgc peat & $3,365 \pm 155$ & $3,459-3,829$ \\
\hline TA-BB & $16.0 \Omega(4.88 \mathrm{~m})$ & $G X-12199$ & Sedge peat & 1,320 上340 & $930-1,550$ \\
\hline TA-B8 & $21.2 \Omega(6.46 \mathrm{~m})$ & $G X-11351$ & Scdge peal & 1,915 上130 & $1.710-2,039$ \\
\hline TA-B8 & $25.0 \cap(7.62 \mathrm{~m})$ & $G X-11352$ & Organic silt & 3,205 上 195 & $3,219-3,683$ \\
\hline TA-B8 & $30.2 \cap(9.21 \mathrm{~m})$ & $G X-11353$ & Woody peal & $2,635 \pm 145$ & $2,549-2,869$ \\
\hline TA-88 & do. & $G \times-11740$ & do. (Samc samplc) & $2,850 \pm 150$ & $2,789-3,209$ \\
\hline \multicolumn{3}{|c|}{ Weighted average of above two analyses } & & $2,739 \pm 104$ & $2,759-2,949$ \\
\hline TA-B8 & $35.2 \cap(10.73 \mathrm{~m})$ & GX-11354 & Organic silly clay & $3,790 \pm 175$ & $3.925-4.429$ \\
\hline TA-B8 & $41.5 \cap(12.65 \mathrm{~m})$ & $G X-11355$ & Plant fragments & $4.240 \pm 195$ & $4,529-5,041$ \\
\hline
\end{tabular}

${ }^{2}$ Calibration to calendar years B.P. is based on data scls for trec rings of known ages (Linick and others, 1985, 1986; Kromer and others, 1986; Pürrsin and Slujver, 1986; Pcarson and olhers, 1986; alskl Sluiver and Pearson, 1986). 
southwestern Washington as evidence of repeated caseismic subsidence in the Cascadia Subduction Zone.

Table 1 reports the radiocarbon ages of organic layers sampled in 1985. Sampling revealed four peat layers below the 1964 peat to a depth of $26 \mathrm{ft}(8 \mathrm{~m})$ at the Girdwoot site. Radiocarbon ages of these peats indicate four pre-1964 subsidence events during the past $3.5 \mathrm{ka}$. At the Portage site, organic layers to depths up to $41 \mathrm{ft}$ $(12.5 \mathrm{~m})$ represent five pre-1964 subsidence events during the past $4.5 \mathrm{ka}$. Because sampling at these sites was not continuous, there may be undiscovered peat layers representing additional subsidence events during the past $4.5 \mathrm{ka}$. Bartsch-Winkler and Schmoll (1987) document buried peat layers with different radiocarbon ages at numerous other locations in the intertidal zone of upper Cook Inlet.

The goal of the current project was to document as completely as possible late-Holocene sedimentation and coseismic subsidence events in two separate basins. The method used to accomplish this goal was to drill boreholes with continuous sampling at the same sites drilled at Girdwood and Portage in 1985 and at new sites along Knik Arm. In most areas of the tidal hat and coastal marsh, drilling is necessary to sample sediments and peats doeper than about $6 \mathrm{ft}(2 \mathrm{~m})$ because bluff exposures are limited.

This study has confirmed that at least a partiat record of prehistoric subsidence events is preserved at the drilled locations in both estuaries. Although a complete record of all observed peats has not yet appeared at any single borehole location, radiocarbon ages of several peats correlate reasonably well between two or more borehole locations and with terrace ages on Middleton Island in the 1964 uplift zone.

\section{FIELD PROGRAM}

\section{EQUIPMENT AND LOGISTICS}

Boreholes were drilled at nine locations on vegetated supratidal flats, including sites at Girdwood and Portage along Turnagain Arm in September 1988 and at Goose Bay and Palmer Hay Flats along Krik Arm in Jatuary and February 1989 (fig. 4). All boreholes were drilled with a truck- or track-mounted CME-75 drill rig operated by the Alaska Department of Transportation and Public Facilities (fig. 5). The 40,000-1b reaction load of this drill rig allowed the sampler to be pushed into the sediment without the use of a hammer, reducing artificial sample compaction and disturbance.

\section{SAMPLE COLLECTION}

Samples were collected using a continuous-sampletube system in conjunction with the hollow-stem auger (fig. 6). The sampler consisted of a 5-ft-long $(1.5-\mathrm{m})$, 3.25-in. $(8.3-\mathrm{cm})$ inside diameter split steel barrel, which was connected to the drill rig with non-rotating rods through the hollow auger. Two clear plastic liners, each $2.5 \mathrm{ft}(76 \mathrm{~cm})$ long and $2.5 \mathrm{in}$. $(6.4 \mathrm{~cm})$ diam were placed end-to-end in the barrel. The cutting head of the sampler extended a short distance ahead of the lead auger, which rotated around the sampler. Drilling and sampling occurred simultaneously in 5-ft $(1,5-\mathrm{m})$ intervals. Samples were retrieved by lifting the sampler to the surface through the hollow-stem auger, disassembling the split barrel, and removing the filted sample liners.

As the full sample liners were retrieved from the sampler, the ends were immediately covered with plastic caps, sealed with tape, and labeled with sample number, depth, and up direction. Sample material caught in the cutting head was retained in sealed plastic bags. A generalized sample log was prepared in the field in conjunction with the drilling log (Combellick, 1990, appendix A). Detailed sample logging was postponed until the samples could be opened in the laboratory.

Successful sample recovery ranged from 78 to 94 percent. Two circumstances resulted in occasional incomplete sample recovery. First, when very firm material-such as dense peat, frozen soil, or a large pebble-had formed over less-firm material, it sometimes plugged the cutting head and forced the softer material under it to the outside of the sample barrel as the sampler penetrated farther. Second, while retrieving loose, wet sand or silt with no clay for cohesion, part of the sample occasionally flowed out of the sampler.

Samples were placed upright in crates for transportation and stored in the crates until they were opened in the laboratory.

Elevation of the ground surface relative to mean higher high water (MHHW) at each borehole locasion was calculated from the surveyed ground elevation above mean sea level (MSL) and published sea-level statistics from the nearest tide-gage stations (U.S. Department of Commerce, 1988). The level of borehole sanuples relative to MHHW must be known to show that the subsurface peat layers are now below the minimum elevation at which they could have formed and to document the minimum amount of subsidence and sedimentation that has occurred since their submergence and burial. 


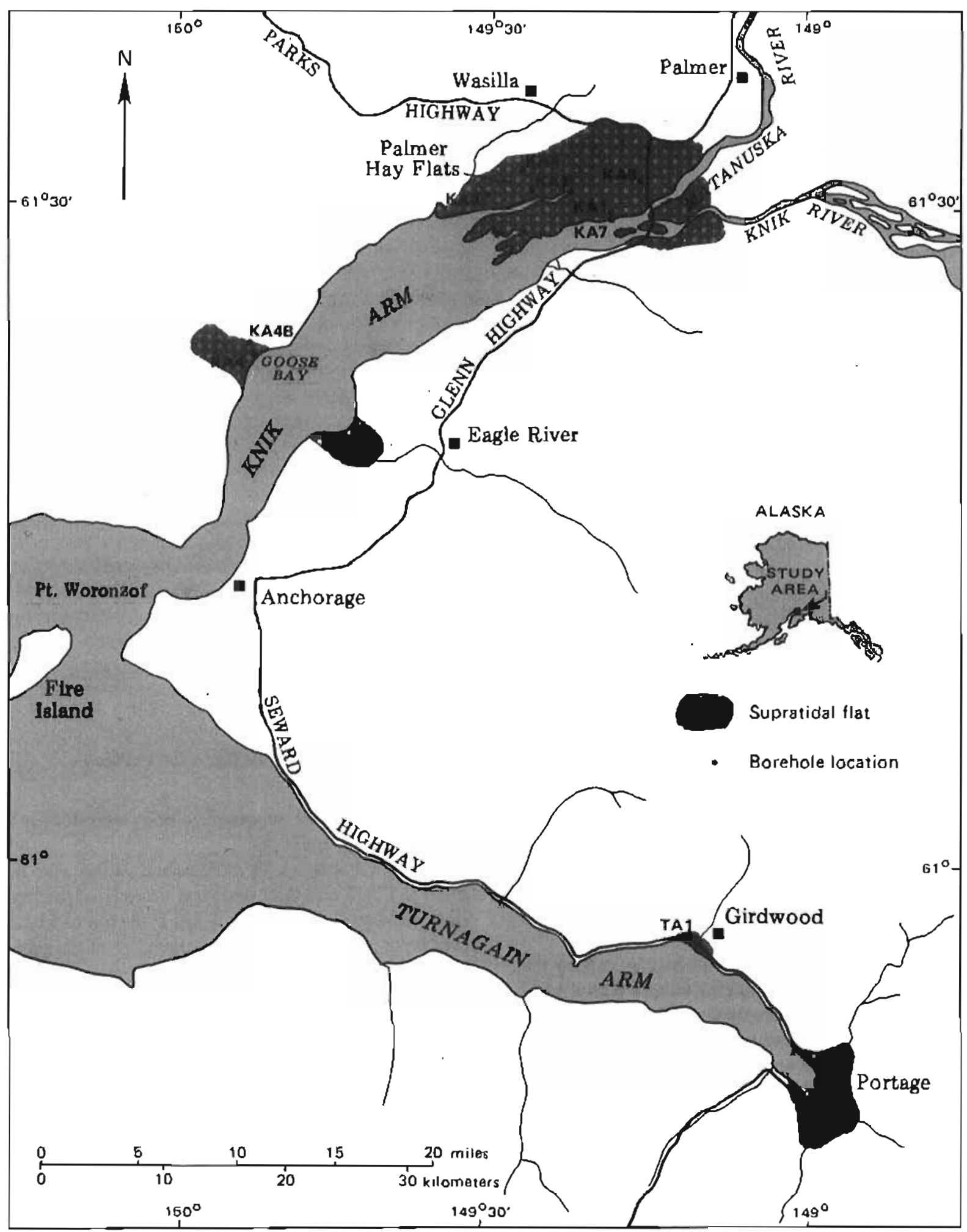

Figure 4. Locarion map of region neur Anchorage, Alaska, showing locations of boreholes drilled on suprasidal Jats in 1988 and 1989. 


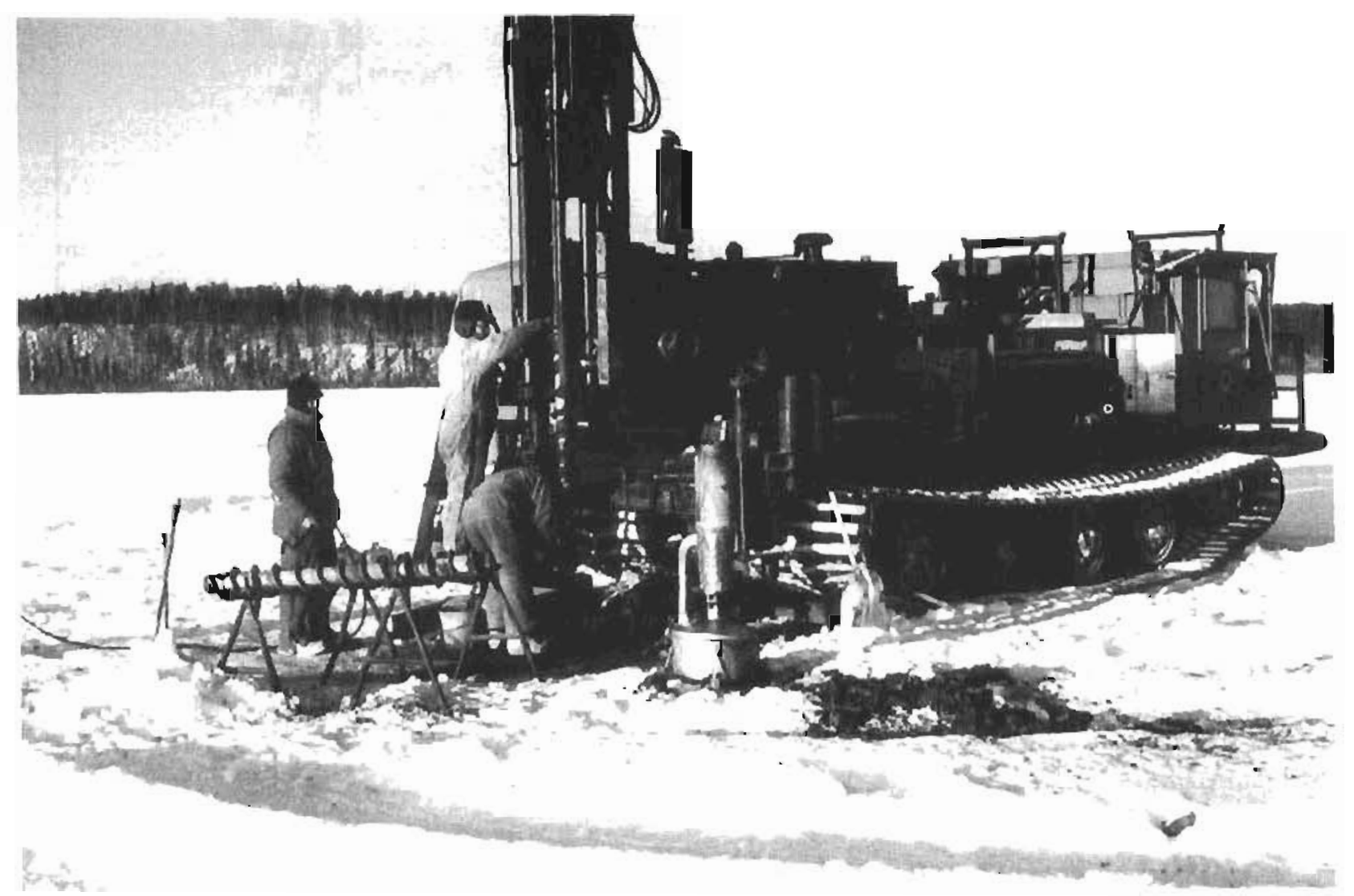

Figure 5. Borehole drilling at sire KA4 near Goare Bay in January 1989 (see fig. 4 for locarion).

\section{LABORATORY ANALYSES}

\section{CORE IOGGING AND SUBSAMPLING}

Each core sample was split in half by cutting the plastic liner and slicing through the sample with a sharp knife or thin wire. Each sample was kept in its semicircular liner halves, which served as trays for handling and storage. After cleaning and smoothing the surface, the sample was described in detail (appendix A) and photographed with high-resolution black-and-white film. A tape measure was placed by each sample and registered to the top of the sample so that pholograplis could be keyed direclly to sumple logs.

Subsamples for radiocarbon daling and granulometric analyses were collected from one side of the split samples. Intact (archive) balves and the remainder of the subsampled halves were covered by plastic wrap and sinred in core boxes for possible future use.
Exact depths of all subsamples were recorded in the sample log (appendix A).

Peat subsamples for radiocarbon dating were normally $0.1 \mathrm{fl}(3 \mathrm{~cm})$ thick and were taken from the top of each peat layer. A radiocarbon age at the top of a buried peat Jayer provides a close maximum age of the ground surface al time of burial. If the peat layer was less than $0.1 \mathrm{ft}$ thick, the entire layer was removed from the sample half to ensure sufficient quantity for dating. A total of 43 subsamples was collected from the nine boreholes for possible radiocarbon dating.

Some subsamples collected for radiocarbon dating were composed of organic silt or disseminated fine organic malter that may represent relict peat layers or may contain reworked or transported organics. These samples were collecled primarily to oblain ages for calculation of sedimentation rates in portions of cores that were devoid of peats. Radiocarbon ages obtained from these samples are regarded with some suspicion because they may be contaminated by older detrital organic material. 


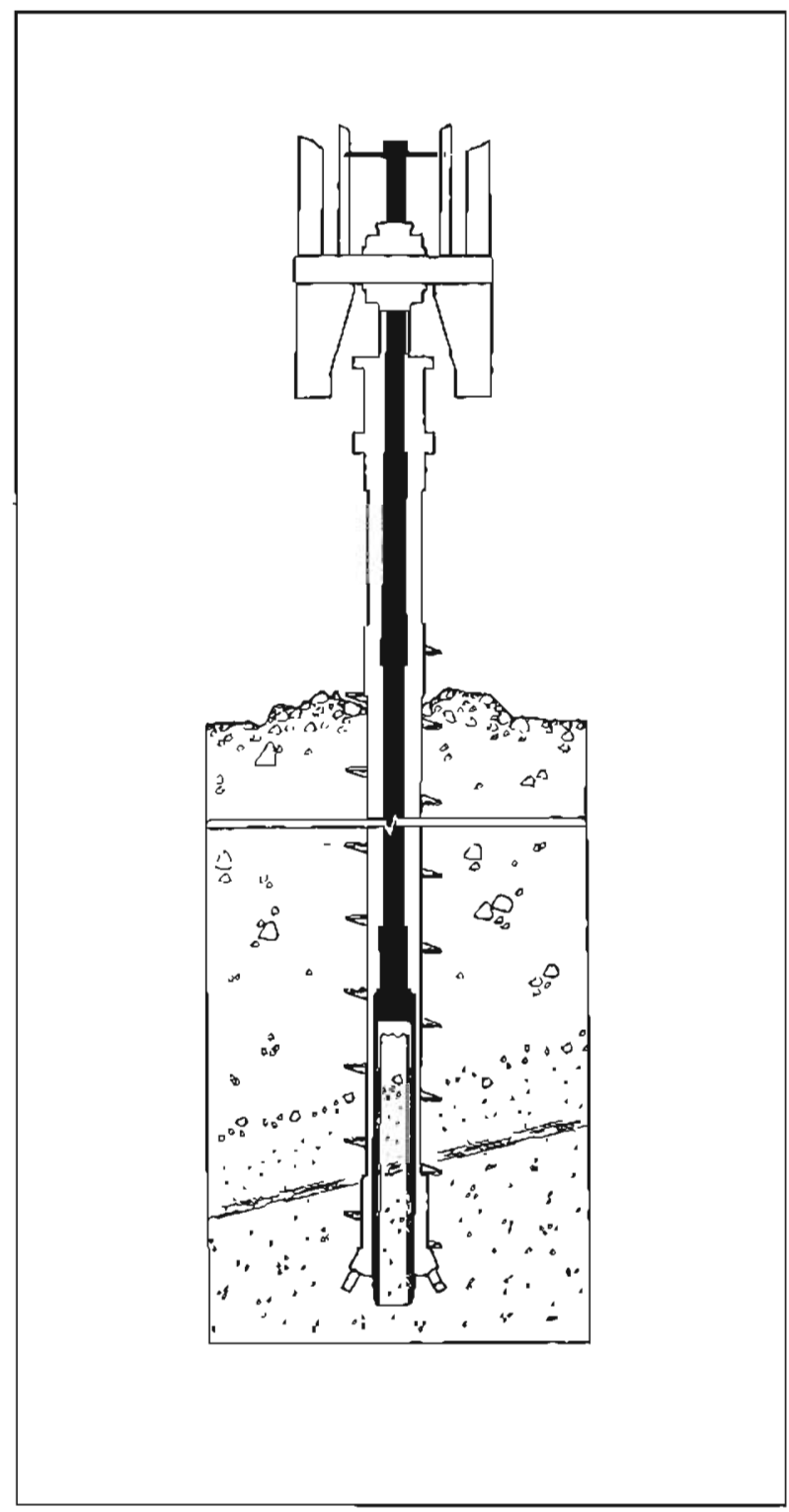

Figure 6. Cross section of hollow-stem auger with continuous-sampling system (solid black). Drilling and sampling occur simultaneourly in $5-f t(1.5-\mathrm{m})$ incremens as the non-rolating sample barrel pushes ahead of the auger. Diagram provided by Central Mining Equipmens.

A total of 55 subsamples was collected for grainsize analyses of distinct stratigraphic units as an aid to interpreting depositional processes. These subsamples were also normally $0.1 \mathrm{ft}(3 \mathrm{~cm})$ thick.

Following completion of logging, photography, and subsampling, each core-sample half was wrapped in clear plastic and stored in a core box for possible future use.

\section{RADIOCARBON DATING}

Subsamples collected for radiocarbon dating were oven dried, weighed, and examined macroscopically for contaminants, such as roots of younger plants or trans. ported older organics, which were removed. Dry subsample weights ranged from $3.6 \mathrm{~g}$ for low-asb peat to $149 \mathrm{~g}$ for silt with disseminated organic matter.

Of 43 organic subsamples collected from the cores, 38 were submitted to Geochron Laboratories Division, Krueger Enterprises, Inc., for radiocarbon dating. Three of the samples required acceleration mass spectrometry because they contained too little carbon for conventional gas-proportional age determination. Two additional samples, KA7-3.0 and KA7-3.5, collected along the Matanuska River bank at location KA7 (fig. 4) were also submitted. Sample KA7-3.0 consisted of flattened fragments of wood branches lying parallel to bedding at a depth of $3.0 \mathrm{ft}(0.9 \mathrm{~m})$. Sample KA7-3.5 was collected from a thin $(<0.1 \mathrm{ft}$ or $3 \mathrm{~cm})$ buried peat at $3.5 \mathrm{ft}(1.1 \mathrm{~m})$ below the ground surface.

Reported radiocarbon ages (table 2) are based on the Libby half life for ${ }^{16} \mathrm{C}(5,570 \mathrm{yr})$ and referenced to AD 1950. A correction for ${ }^{13} \mathrm{C} /{ }^{12} \mathrm{C}$ was applied to adjust for natural isolopic fractionation. Conventional ages were calibrated to tree-ring ages (tables $\{$ and 2 ) using a procedure described by Stuiver and Reimer (1986).

\section{PLANT IDENTIFICATION}

Twenty two of the organic ssmples were submitted to the University of Alaska Museum for identification of plant remains contained in the submerged peat layers. Plant identifications are presented in table 3.

\section{GRAIN-SIZE ANALYSES}

Subsamples for grain-size analyses were oven dried and weighed. Subsample weights ranged from $50 \mathrm{~g}$ to $290 \mathrm{~g}$. Six coarse-grained subsamples were anslyzed with conventional 8-in.-diam $(20.3-\mathrm{cm})$ sieves. The remaining 49 fine-grained subsamples were analyzed with a Micromeritics Sedigraph 5000ET rapid sediment analyzer.

Results of the analyses of two sample splits from each fine-grained sample were recorded automatically by the Sedigraph on chart paper. The graph was then scaled in full or half phi $(\phi)$ units to compute size distributions in weight percent. A third split was analyzed for any sample when results for the first two splits had an error greater than 5 percent in the size distribution. Mean grain 
Table 2. Radiocarbon ages of scamples from boreholes drilled in vicinity of Tumiagain and Krik Ams in 1988 and 1989.

\begin{tabular}{|c|c|c|c|c|c|}
\hline $\begin{array}{l}\text { Bore: } \\
\text { hole }\end{array}$ & Depth. & $\begin{array}{l}\text { Laboratory } \\
\text { number }\end{array}$ & Material dated & $\begin{array}{l}\text { Radiocarbon } \\
\text { age (yr B.P.) }\end{array}$ & $\begin{array}{l}\text { Calibrated } 10 \text { age } \\
\text { range (ur B.P.) }\end{array}$ \\
\hline TAI & $6.4 \mathrm{ft}(1.95 \mathrm{~m})$ & $a x-15208$ & Sphagnum-sedge peat & negative (post- & $950)$ \\
\hline TA1 & $8.8 \mathrm{ft}(2.68 \mathrm{~m})$ & $6 X-15209$ & Woody moss-sedge peat & $510 \pm 130$ & $480-660$ \\
\hline TA1 & $12.8 \mathrm{ft}(3.90 \mathrm{~m})$ & $6 x-15210$ & Sedgo peat & 815 主115. & $670-907$ \\
\hline TAI & $19.7 \mathrm{~A}(6.01 \mathrm{~m})$ & $6 x-15212$ & Sphagnum-aedge peat & $2 ; 100+75$ & $1,988-2,285$ \\
\hline TAI & $21.2 \mathrm{t}(6.46 \mathrm{~m})$ & $G X-15211$ & Sodgo-wood peat & $1,875+125$ & $1,635=1,950$ \\
\hline TAL & $22.6 \mathrm{ft}(6.89 \mathrm{~m})$ & $a x-15213$ & Woody moss-sedge peat & $2,755 \pm 80$ & $2,774-2 ; 950$ \\
\hline TAl. & $25.5 \mathrm{t}(7.77 \mathrm{~m})$ & $G X-15214$ & Sphagniun-sedge peat & $3,455 \pm 145$ & $3,559-3,909$ \\
\hline TA1 & $55.3 \mathrm{ft}(16.86 \mathrm{~m})$ & $G X-15215$ & Órganio int & $10,375 \pm 310$ & (too old to cy \\
\hline TA8. & $4.9 \mathrm{fl}(1.49 \mathrm{~m})$ & $G X-15216$ & Sedgo blades \& roots & $330+150$ & $<0^{k}-520$ \\
\hline TA8 & $7.0 \mathrm{ft}(2.13 \mathrm{~m})$ & GX-15217-AMS & Soatuened organics & $1,030 \pm 130$ & $790-1,060$ \\
\hline TAB & $12.7 \mathrm{ft}(3.87 \mathrm{~m})$ & $G X-152: 18$ & Sphagnum-sedge peat & $885 \pm 120$ & $690-930$ \\
\hline TA8 & $13.4 \mathrm{ft}(4.09 \cdot \mathrm{m})$ & GX-15404 & Sedge peat & $1,495 \pm 165$ & $1,280-1,550$ \\
\hline TA8 & $20.3 \mathrm{ft}(6.19 \mathrm{~m})$ & GX-15219 & Mosisedge peat & $1,695 \pm 80$ & $1,527-1,709$ \\
\hline TAB & $21.5 \mathrm{f}(6.55 \mathrm{~m})$ & GX-15405 & Sedge peat & $2,630 \pm 80$ & $2 ; 740-2,792$ \\
\hline TA8 & $24.8 \mathrm{ft}(7.56 \mathrm{~m})$ & $G X-15220$ & Woody moss-sedge peat & $2,675 \pm 80$ & $2,749-2,857$ \\
\hline TA8 & $30.3 \mathrm{t}(9.24 \mathrm{~m})$ & GX-15221 & Moss-sedge peat & $2,705 \pm 85$ & $-2,754-2,876$ \\
\hline TA8 & $36.2 \mathrm{ft}(11.04 \mathrm{~m})$ & $0 x-15222$ & Thin peat. & $3,0.15+140$ & $2,989-3 ; 979$ \\
\hline TA8 & $41.5 \mathrm{ft}(12.65 \mathrm{~m})$ & GX-15223 & Thin peat & $4,150 \pm 130$ & $4,455-4,859$ \\
\hline TA8 & $50.8 \mathrm{ft}(15.49 \mathrm{~m})$ & $G X-15224$ & Organic silt & $10,730 \pm 525$ & (wo old to calibrate) \\
\hline KAl & $1.7 \mathrm{ft}(0.52 \mathrm{~m})$ & GX-15406 & Wood-sedge-noss peat & negative (pos & $950)$ \\
\hline KA1B & $2.7 \mathrm{ft}(0.82 \mathrm{~m})$ & GX-15225 & Wood-sedgc-moss peat & $470 \pm 70$ & $489-544$ \\
\hline $\mathrm{KA1}$ & $5.85 \mathrm{ft}(1.78 \mathrm{~m})$ & $G x-15226$ & Sedge peat & $955 \pm 75$ & 784943 \\
\hline KA1 & $11.75^{\circ} \mathrm{ft}(3.58 \mathrm{~m})$ & $a X-15227$ & Sedgie pieat & $2,080 \pm 130$ & $1,890-2,307$ \\
\hline KAI & $18.2 \mathrm{n}(5.55 \mathrm{~m})$ & $G X-15228$ & Scattored organios & $7,240 \pm 295$ & $7,729-8,369$ \\
\hline KA1 & $28.2 \mathrm{ft}(8.60 \mathrm{~m})$ & GX-15229-AMS & Organio silt & $8,850 \pm 120$ & (too old to calibratc) \\
\hline KA4 & $0.7 \mathrm{ft}(0.21 \mathrm{~m})$ & $G X-15230$ & Wood-sedge peat & negative (post- & 950) \\
\hline KA4 & $3.3 \mathrm{ft}(1.01 \mathrm{~m})$ & $G X-15231$ & Wood-sedge peat & $515 \pm 75$ & $507-628$ \\
\hline KÁ4 & $24: 2 \mathrm{ft}(7.38 \mathrm{~m})$ & GX-15232-AMS & Organio silt & $4,533 \pm 84$ & $4,996-5,317$ \\
\hline KA4B & $3.1 \notin(0.95 \mathrm{~m})$ & GX-15407 & Wood-sedge peat & $145 \pm 75$ & $<0-290$. \\
\hline $\mathrm{KA4B}$. & $5.8 \mathrm{ft}(1.77 \mathrm{~m})$ & $G X-15233$ & Wood-sedge-moss peat & $510 \pm 70$ & 507.623 \\
\hline $\mathrm{KA4B}$ & $12.7 \mathrm{~A} \cdot(3.87 \mathrm{~m})$ & $G X-15234$ & Organio sill & $9,25 \overline{5} \pm 420$ & (too old to calibrate) \\
\hline KAS & $5.0 \mathrm{ft}(1.52 \mathrm{~m})$ & $G X-15235$ & Wood-mosg-sedge peat & $1,080 \pm 85$ & $930-1,066$ \\
\hline KA6 & $2.3 \mathfrak{f}(0.70 \mathrm{~m})$ & $G X-15236$ & Silty wood-sedge peat & $185 \pm 130$ & $<0-424$ \\
\hline KAG & $3.0 \mathrm{ft} \cdot(0.91 \mathrm{~m})$ & $G X-15237$ & Sedge peat & $560 \pm 70$ & $523-650$ \\
\hline KAG & $4.35 \mathrm{f}(1.33 \mathrm{~m})$ & $G X-15238$ & Sedge peat & $930 \pm 115$ & $720-960$ \\
\hline KA6 & $7.55 \mathrm{ft}(2.30 \mathrm{~m})$ & GX:15239 & Organic gilt & $2,810 \pm 200$ & $2,749-3219$ \\
\hline KÁG & $7.85 \mathrm{ft}(2.39 \mathrm{~m})$ & $G X-15240$ & Woody peit & $1,800 \pm 125$ & $1,560-1,880$ \\
\hline KÁ6. & $25.3 \mathrm{f}(7.71 \mathrm{~m})$ & $G X-15241$ & Organie silt & $11,400 \pm 720$ & (too old to calibrate) \\
\hline KA7 & $3.0 \mathrm{ft}(0.91 \mathrm{~m})$ & GX-15466 & Wood $\mathrm{f}$ & $520 \pm 70$ & $510-628$ \\
\hline KA7 & $3,5 \mathrm{ft}(1.07 \mathrm{~m})$ & $G X-15465$ & Wood-sedge peat & $495 \pm 120$ & $472-641$ \\
\hline
\end{tabular}

- Calibration to calendar years B.P. is based on data sets for tree rings of known ages (Linick and others, 1985, 1986; Kromer and others, 1986; Pearson and Stuiver, 1986; Pearson and others, 19.86; Stuiver and Pearson, 1986; and Stuiver and others, 1986).

$b<0=$ negative calibrated age B.P. (post-1950). 
Table 3. Identification of plant fragments in buried peats and organic-rich layers

Sample

TA. $1-6.4$

TAl-8.8

TAI -12.8

TA1 $-19,7$

TA $1-21.2$

TA1-22.6

TA1-25.5

TA8-12.7

TA8-20.3

TA8-24.8

TA8-30.3 $30.3 \mathrm{ft}(9.24 \mathrm{~m})$

TA8B-7.0

KA1 -5.85

KA $1-11.75$

KA1B-2.7

$\mathrm{KA} 43.3$

KA4B-5.8 $\quad 5.8 \cap(1.77 \mathrm{~m})$

KA.5-5.0

$$
6.4 \mathrm{ft}(1.95 \mathrm{~m})
$$

$8.8 \mathrm{ft}(2.68 \mathrm{~m})$

$12.8 \mathrm{n}(3.90 \mathrm{~m})$

$19.7 \mathrm{i}(6.01 \mathrm{~m})$

$21.2 \mathrm{f}(6.46 \mathrm{~m})$

$22.6 \mathrm{ft}(6.89 \mathrm{~m})$

$25.5 \bigcap(7.77 \mathrm{~m})$

12.7 ft $(3.87 \mathrm{~m})$

$20.3 \mathrm{ft}(6.19 \mathrm{~m})$

$24.8 \mathrm{ft}(7.56 \mathrm{~m})$

$7.0 \mathrm{~A}(2.13 \mathrm{~m})$

$5.85 \mathrm{ft}(1.78 \mathrm{~m})$

$11.75 \AA(3.58 \mathrm{~m})$

$2.7 \mathrm{ft}(0.82 \mathrm{~m})$

$3.3 \mathrm{ft}(1.01 \mathrm{~m})$

$5.0 \cap(1.52 \mathrm{~m})$

KA6-2.3 $2.3 \mathrm{ft}(0.70 \mathrm{~m})$

KAG-3.0 $3.0 \mathrm{ft}(0.91 \mathrm{~m})$

KA6-4.35

KA $6-7.85$
$4.35 n(1.33 \mathrm{~m})$

$7.85 \mathrm{t}(2.39 \mathrm{~m})$ Composition

Moss-sedge peat (Calliergon and Sphagnum).

Sedge-moss (Sphagnum?) peat (mostly sedge). Some wood up to $3 \mathrm{~mm}$ diam.

Sodge peat with some moss and wood.

Moss (Sphagnum?)-sedge peat with twigs up to $5 \mathrm{~mm}$ diam.

Well-preserved sedge peat with lots of wood (maximum diameter $3 \mathrm{~mm}$ ).

Moss (Sphagnum?)-sedge pest with some wood up to $4 \mathrm{~mm}$ diam.

Sphagnum peat with a few scdges.

Sphagnum(?) peat with a few sedges and fine $(1.2 \mathrm{~mm})$ woody roots or twigs.

Silty moss-sedge peat, mostly moss (non-Sphrgnum?). No twigs apparent.

Decomposed moss (non-Sphagnum?)-sedge pear with some woody twigs up to $2 \mathrm{~mm} \operatorname{dis}$.

Moss-sedge peat (mostly moss, Drepanocladus and Calliergon), with a few woody twigs up to $2 \mathrm{~mm}$ diam.

Sand with sedge \& wood fragments.

Well-decomposed sedge peat.

Silt with some sedge-like organic fragments. Possibly same wood fragments.

Well-preserved sedge peat with abundant wood with bark; twigs maximum diameter $4-5 \mathrm{~mm}$.

Sedge peat with abundant well-prescrved wood with bark (maximum diameter about $1 \mathrm{~cm}$ ).

Moss-scdge peat (Sphagnum?) with abundant wood (and bark?) fragments. Well-preserved twigs, maximum diameler $5.5 \mathrm{~mm}$.

Moss-sedge peal (moss componen! Tomenlhypnum and Sphagnum) with several twigs (maximum $3 \mathrm{~mm}$ diam) wilh bark and leaf scars. Tomenthypnum is often calcarcous.

Silly sedge peat with wood twigs (maximum diamcter $3 \mathrm{~mm}$ ). No moss apparent.

Sedge pcat with some moss (non-Sphagnum). No wood apparent.

Sedge pcat, possibly with some woody roots. No mosses apparent.

Fine-grained mineral with wood fragments up to $9 \mathrm{~mm}$ diam, $2 \mathrm{~cm}$ long.

adentifications by A.R. Ballen and B.M. Murray, University of Alaska Museum, 1989. 
size, standard deviation (sorting), skewness (asymmetry), and kurtosis (peakedness) were calculated from phi-size distributions using standard procedures for moment measures (Friedman and Johnson, 1982) and are reported with percent gravel, sand, silt, and clay in appendix B.

\section{RESULTS}

\section{LITHOLOGY AND STRATIGRAPHY}

Subsurface sediment at all boreholes and sections is predominantly clayey silt to fine sandy silt, similar to material on the modern intertidal flats (see fig. 7 for graphic logs, appendix A for detailed sample descriptions), although layers of coarser sand and gravel are present in the upper parts of the Girdwood and Portage boreholes. Gravel comprising the upper $6 \mathrm{ft}(2 \mathrm{~m})$ of borehole TA1 at Girdwood is road fill. Fine to medium sand in the upper $10 \mathrm{ft}(3 \mathrm{~m})$ of borehole TA 8 at Portage displays more distinct layering, coarser grain sizes, and size grading than the remaining fine-grained samples and is interpreted as fluvial overbank deposits from Portage Creek.

The fine sediment making up the remainder of the borehole samples is mostly structureless to faintly laminated clayey silt and silty clay (see appendix B for graphic logs of grain-size statistics). Contorted bedding is rare and is attributed in most cases to disturbance during sampling and handling. In these cases, contorted bedding is restricted to soft sediment adjacent to the void at the top of the cores and extends downward along the core walls. Strongly contorted bedding that casnot be attributed to sample disturbance appears only in the botton $3 \mathrm{ft}(1 \mathrm{~m})$ of borehole KA6 in upper Knik Arm at depths of 40.5 to $43.5 \mathrm{ft}$ ( 12.3 to $13.3 \mathrm{~m}$ ) (appendix A). No buried peat layers are clearly assaciated with contorted bedding at this or any other location.

Drilling revealed subsurface peat layers at all borehole locations. These peats are composed of fresh-water grasses, mosses, and some wood (table 3 ). In boreholes KA2, KA3, and KA5 on Palmer Hay Flats and in KA4 and $K A 4 B$ at Goose Bay, the peat layers all appear within $6 \mathrm{ft}(2 \mathrm{~m})$ of the surface. These peat layers are immediately below zones that could not be sampled because of the wet, very loose condition of the soil beneath the frozen ground. Therefore, it is not possible to determine from these samples whether these near-surface peats are buried beneath intervening layers of silt or are parts of a single surface layer of peat.

Deeper subsurface peats interlayered with silt appear in boreholes TA1 and TA8 in Turnagain Arm, KAI and KA6 on Palmer Hay Flats, and at section KA7 exposed in the bluff at the mouth of the Matanuska River near KAI. In borehole TA1 at Girdwood, four distinct peat layers 0.3 to $1.3 \mathrm{ft}$ thick $(0.1$ to $0.4 \mathrm{~m})$ are overlain by 0.3 to $6.5 \mathrm{ft}(0.1$ to $2.0 \mathrm{~m})$ of nearly organic-free silt, minor sand, and some pebbles. Two additional peat layers at 8.5 and $21.1 \mathrm{ft}(2.6$ and $6.7 \mathrm{~m})$ depth appear below sample breaks and may or may not be separate layers. The deepest pest layer is at $25.5 \mathrm{ft}(7.8 \mathrm{~m})$; all are below present MHHW.

In borehole TA8 at Portage, six peat layers 0.1 to $0.8 \mathrm{ft}$ thick ( 3 to $24 \mathrm{~cm}$ ) are overlain by 0.2 to $6.7 \mathrm{ft}(0.06$ to $2.0 \mathrm{~m}$ ) of organic-free clayey silt and fine sandy silt. Two additional thin peat seams (less than $0.05 \mathrm{ft}$ or $1.5 \mathrm{~cm})$ in otherwise uniform silt appear at 36.2 and $41.5 \mathrm{ft}$ depths ( 11.0 and $12.7 \mathrm{~m}$ ) and may represent former supratidal surfaces. All subsurface peats in this borehole are below present MHHW.

Borehole KA1 on Palmer Hay Flats contains two thin peats overlain by silt below the surface organic layer. These peats occur at 5.8 to $6.0 \mathrm{ft}(1.77$ to $1.83 \mathrm{~m})$ and 11.7 to $12.0 \mathrm{ft}(3.57$ to $3.66 \mathrm{~m}$ ) below present MHHW. Borehole KA6 contains three well-developed peats interlayered with silt at 3.0 to $3.2 \mathrm{ft}(0.91100 .98 \mathrm{~m}), 4.3$ to $4.6 \mathrm{ft}(1.31$ to $1.40 \mathrm{~m})$, and 7.8 to $7.9 \mathrm{ft}(2.38$ to $2.41 \mathrm{~m}$ ). An additional 0.05 -ft or $1.5-\mathrm{cm}$-thick organicrich layer that appears to be a weakly developed peat is present at 7.5-ft (2.3-m) depth. The uppermost peat layer is about at the level of present MHHW.

A 6-ft-high $(1.8-\mathrm{m})$ bluff section near the mouth of the Matanuska River at the edge of Palmer Hay Flats (location KA7 on fig. 4) consists mainly of silt, with scattered organics and roots near the surface. The soction also contains a layer of compressed wood fragments at $3.0 \mathrm{ft}(0.9 \mathrm{~m})$ and a thin layer of peat at $3.5 \mathrm{ft}(1.1 \mathrm{~m})$. These organic layers are slightly above MHHW. The peat layer was initially thought to represent the pre-1964 vegetation, because its depth corresponds approximately to the amount of subsidence documented in this area for the $\$ 964$ earthquake. However, radiocarbon dating places both the wood layer and peat at an uncalibrated age of about 500 yr B.P., which corresponds to basal ages obtained for near-surface peats in several other boreholes.

Siratigraphic relations of several buried peat layers indicate that their development and subsequent burial began with gradual shoaling and sparse vegetation growth, followed by dense vegetution and peat development, and then by sudden burial. Peat layers showing this sequence appear at $13 \mathrm{ft}(4.0 \mathrm{~m})$ and $25.5 \mathrm{ft}(7.8 \mathrm{~m})$ in borehole TA. 1 and at $30.5 \mathrm{ft}(9.3 \mathrm{~m})$ in borehole TAB (fig. 8). Silt deposits below these peats show a gradual increase in 


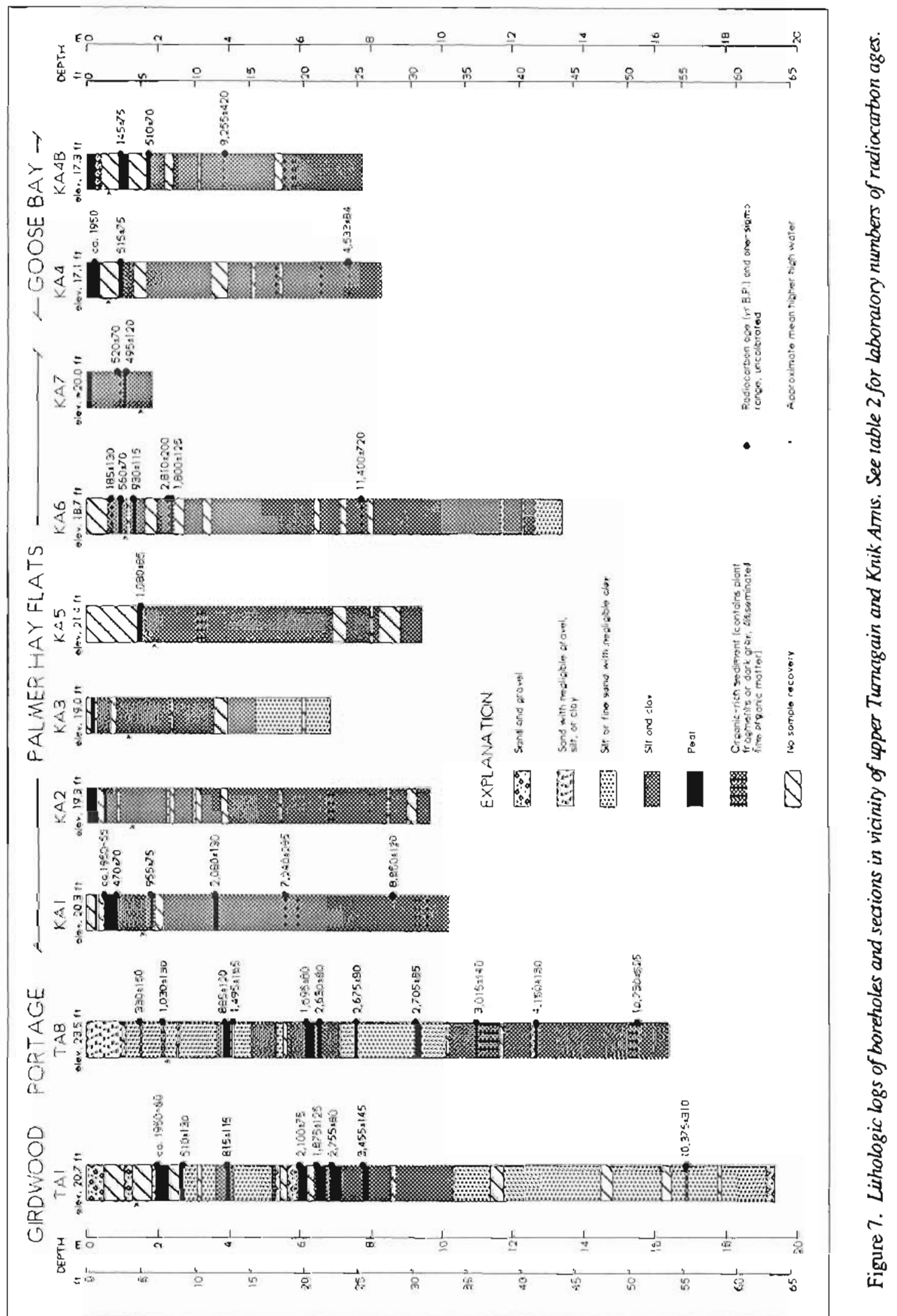


plant and root material with time (upward in the borebole). A gradational contact at the base of the peat indicates a gradual increase in density of vegetation, and a sharp upper contact between the peat and overlying silt attests to sudden burial. The overlying silt is nearly devoid of organics or has only scattered sedge blades or twigs. Scattered organics and a large twig in silt overlying the peat at $13 \mathrm{ft}$ in TAl (fig. 8, A) may be similar to the buried pre-1964 vegetation preserved in tidal channels near Girdwood. There deposits of Placer River Silt (Ovenshine and others, 1976) encase the branches of small bushes that were growing on the supratidal flat at the time of the earthquake on March 27, 1964. Silt immediately overlying the peat at $25.5 \mathrm{ft}$ contains negligible organics but shows a gradual upward increase in organics within about $1 \mathrm{ft}(0.3 \mathrm{~m})$ toward the base of the next higher peat layer at $23 \mathrm{ft}$ depth (7 m) (fig. 8, B).

In addition to the peats, layers of organic sile were found in the boreholes that may or may not represent buried remuants of former supratidal surfaces. These include zones of scattered plant fragments or dark gray, disseminatod fine organic matter embedded in silt (fig. 7). Because of the strong possibility that this organic material was retransported, I assume that these layers are not remnants of peats and use their radiocarbon ages only for calculation of maximum ages and approximate sedimentation rates.

\section{RADIOCARBON AGES}

Radiocarbon ages of selected peats and organic-rich layers are shown in relation to borehole stratigraphy in figure 7. All ages are reported in uncalibrated radiocarbon years before present ( $y r$ B.P.), referenced to A.D. 1950. The most significant effect of tree-ring culibrations is to increase the ages of the oldest samples $(>3,000 \mathrm{yr}$ ) by up to several hundred years (tables 1 and 2). As these differences are probably not significant relative to other sources of error and have no major effect on the conclusions of this report, uncalibrated ages are used in figures to simplify comparisons with other reported data,

In borehole TA1 at Girdwood, the shallowest subsurface peat layer has a negative radiocarbon age (post1950). This peat is probably the remains of surface vegetation that was buried following submergence during the 1964 great Alaska earthquake. Its depth at this location is about the same as the known pre-1964 peat in nearby tidal channels. Dated peat layers below the pre1964 peat yield radiocarbon ages of $510 \pm 130,815 \pm 115$, $2,100 \pm 75,1,875 \pm 125,2,755 \pm 80$, and $3,455 \pm 145 \mathrm{yr}$ B.P. (table 2; fig. 7). A thin layer of organic silt at $55.3 \mathrm{ft}$
$(16.9 \mathrm{~m})$ has a radiocarbon age of $10,375 \pm 310$ yr B.P., providing a minimum age for deglaciation comparable to the 10,180 \pm 350 -yr age obtained for a sample of compressed wood and peat in a gravel pit at Girdwood (Bartsch-Winkler and Schmoll, 1984a).

The 510 -yr date at $8.8 \mathrm{ft}(2.7 \mathrm{~m})$ in TAl is from a sample collected at the base of a peat layer that is immediately below a sample break. It is not possible to determine from these samples whether this peat is a separate layer or is continuous with the peat at 6.4 to $7.4 \mathrm{ft}(2.0$ to $2.3 \mathrm{~m})$.

The 1,875-yr peat layer at $21 \mathrm{ft}(6.4 \mathrm{~m})$ in TA1 is also immediately below a sample break and is discordant with the ages of peats above and below. A plot of age versus depth (Fig. 9, A) shows that this sampie's age is inconsistent with the long-term sedimentation rate indicated by the other radiocarbon ages. The disturbed top of this core sample and the anomalously young age suggest that the sample may be contaminated by younger organic material. Because recovery was not continuous in this sample interval, it is not clear whether there are two separate peats or one continuous peat between 19.7 and $22.2 \mathrm{ft}(6.0$ to $6.8 \mathrm{~m})$.

Radiocarbon ages were obtained for 11 layers in borehole TA8 at Portage: six peat layers more than 1 in. $(2.5 \mathrm{~cm})$ thick, two thin peat seams, and three layers of organic silt. The peats yield ages of $885 \pm 120,1,495 \pm 165$, $1,695 \pm 80,2,630 \pm 80,2,675 \pm 80,2,705 \pm 85,3,015 \pm 140$, and 4,150 130 yr B.P. (table 2; fig. 7). An age discordance occurs between the organic-rich layer at $7.0 \mathrm{ft}(2.1 \mathrm{~m})$ and the peat layer at 12.6-13.3 $\mathrm{f}(3.8-4.0 \mathrm{~m})$. Although either of these ages could be wrong, I regard the 1,030-yr age of the layer at $7.0 \mathrm{ft}$ with suspicion because its organic content is very low, and the fine-grained organic matter may have been retransported. Also, the $885-y r$ age at $12.7 \mathrm{ft}(3.9 \mathrm{~m})$ correlates closely with the $815-y \mathrm{r}$ age at about the same depth in borehole TAI.

Organic silt at $50.8 \mathrm{ft}(15.5 \mathrm{~m})$ near the base of borehole TA8 at Portage yields a radiocarbon age of $10,730 \pm 525 \mathrm{yr}$ B.P. This age is comparable to the lowermost age obtained at TA1 at Girdwood and provides a minimum age of deglaciation of the Portage area. Previously, the oldest radiocarbon age obtained in the Portage area was $8,230 \pm 100$ yr B.P. on wood fragments at the base of a $305-\mathrm{ft}(93-\mathrm{m})$ core about $1 \mathrm{mi}(1.6 \mathrm{~km})$ northwest of TA8 (Bartsch-Winkler and others, 1983). The discrepancy between the depths of these saniples and their ages casts doubt on the validity of one of the ages: although shallower, the sample in TA8 gives the older age and results in a sedimentation rate about one-seventh that of the remainder of the section. This discrepancy may be reason to suspect that the $10,730-y_{r}$ age is erroneous and may represent transported material. However, the 


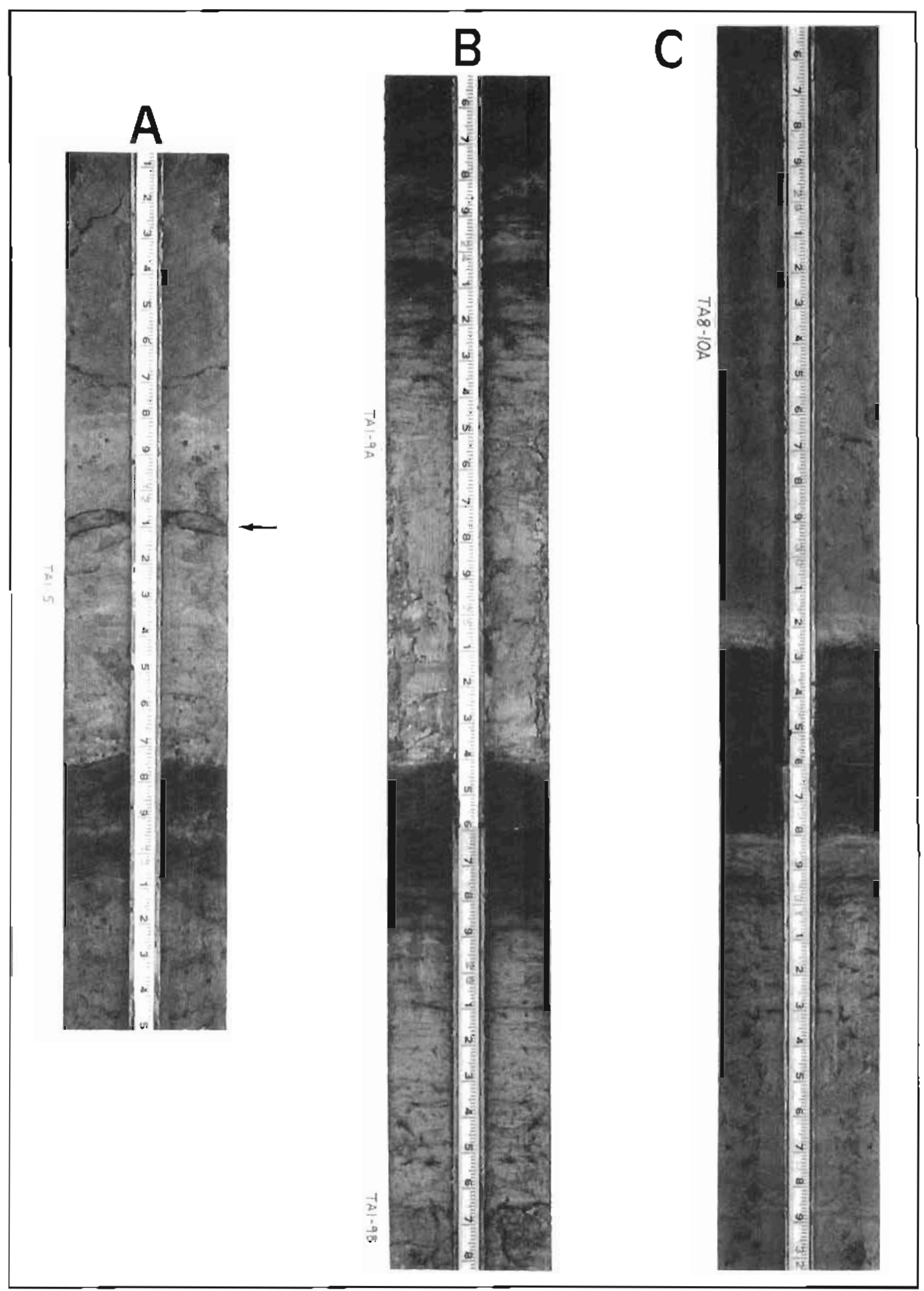

Figure 8. Buried peat layers in boreholes TAI and TA8, showing gradual upward increase in roots and plam fragments below the peats, sharp upper contacts, and nearly organic-free silt and chay overlying the peats. A, peat layer at

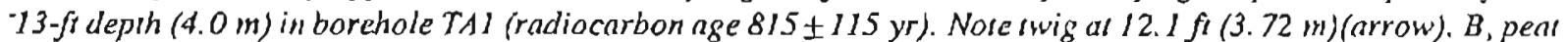
layer al 25.5-fi (7.85-m) depth in borehole TAl (radiocarbon age 3,455 $145 \mathrm{yr}$ ). Upper pan of pholo shuws gradational lower portion of pent layer as $23 \mathrm{ft}(7.08 \mathrm{~m})$ (rudiocarbon age $2,755 \pm 80 \mathrm{yr}$ ). C, peat lcoyer at $30.5-\mathrm{fl}$ deprh $(9.3 \mathrm{~m}$ ) in borehole TA8 (rudiocarbon age $2,705 \pm 85 \mathrm{yr}$ ). 
10,730-yr age correlates closely with the 10,375-yr layer at about the same depth in borehole TA1 at Girdwood (fig. 7), so the question of which date is invalid remains unresolved. Even if the 10,730-yr organics in TA8 were retransported, the date is still a valid minimum age for deglaciation at Portage because the site had to be ice-free at the time the organics were deposited.

In borehole KA1 (Palmer Hay Flats), a thin ( $<1 \mathrm{ft}$ or $30 \mathrm{~cm}$ ) layer of organic silt separates peat at the surface from a buried peat at 1.7 to $2.8 \mathrm{ft}(0.52100 .85 \mathrm{~m})$ (fig. 7 . appendix A). A sample at the top of this buried peat layer yields a negative radiocarbon age (post-1950), and a sample at its base gives an age of $470 \pm 70$ radiocarbon $\mathrm{yr}$ B.P. This latter age correlates closely with ages obtained on layers of wood fragments $(520 \pm 70$ y $\mathrm{B}$.P. $)$ and peat ( $495 \pm 120$ yr B.P.) in rearby tidal-channel section KA7 (table 2; fig. 4 for location). Deeper buried peat layers at 5.8 to $6.0 \mathrm{ft}(1.77$ to $1.83 \mathrm{~m})$ and 11.7 to $12.0 \mathrm{ft}(3.57$ to $3.66 \mathrm{~m}$ ) in KA1 yield radjocarbon ages of $955 \pm 75$ and $2,080 \pm 130$ yr B.P. , respectively. Thin layers of organic silt at 18.2 and $28.2 \mathrm{ft}(5.55$ and $8.60 \mathrm{~m})$ yield radiocarbon ages of $7,240 \pm 295$ and $8,850 \pm 120 \mathrm{yr}$ 8.P., respectively, but may represent transported material.

No buried peat layers were encountered below the surface peat in boreholes KA2 and KA3 on Palmer Hay Flats (figs, 4 and 7 ), so no radiocarbon ages were obtained. Nearby, in borehole KA5, it was not possible to sample the upper $4.7 \mathrm{ft}(1.43 \mathrm{~m})$ of soft, wet peat below the ice. However, a basal peat sample at $5.0 \mathrm{ft}$ $(1.52 \mathrm{~m})$ yields a radiocarbon age of $1,080 \pm 85 \mathrm{yr}$ B.P. This may be the age of the base of the surface peat layer or may be the age of a buried peat that correlates with the peat at $5.8 \mathrm{ft}(1.77 \mathrm{~m})$ in XA1.

Three well-developed buried peats were sampled in borehole XA6 on Palmer Hay Flats at $3.0,4.3$, and $7.8 \mathrm{ft}$ $(0.91,1.31$, and $2.38 \mathrm{~m})$, yietdingages of $560 \pm 70,930 \pm 115$, and 1,800 \pm 125 radiocarbon yr B.P., respectively (fig. 7). A $185 \pm 130$-yr age for organic matter in silt at $2.3 \mathrm{ft}(0.70 \mathrm{~m})$ at the top of the first core probably represents surface peat mixed with silt through sample disturbance. Layered organic silt at $7.55 \mathrm{ft}(2.30 \mathrm{~m})$ yields a radiocarbon age of $2,810 \pm 200 \mathrm{yr}$ B.P., which is discordant with ages above and below (fig. 9, F), but correlates closely with ages of welldeveloped peats in boreholes TAI and TA8 at Girdwood and Portage. A deeper lamina of organic sitt at $25.3 \mathrm{ft}(7.71 \mathrm{~m})$ dates at $11,400 \pm 720 \mathrm{yr}$ B.P., which, if valid, providesa new minimum age at this location for retreal of glacial ice after the late-Wisconsin Elmendorf advance (Regerand Updike, 1983).

At borehole KA4 (Goose Bay), a negative radiocarbon age (post-1950) was obtained for peat at the base of the recovered portion of surface organics (fig. 7). A sample break at 1.2 to $3.0 \mathrm{ft}(0.37$ to $0.91 \mathrm{~m})$ makes it difficult to determine whether peat at 3.0 to $3.35 \mathrm{ft}(0.91$ to $1.02 \mathrm{~m}$ ) is the base of the surface organic layer or is buried under intervening silt. The age of a sample at the base of this layer is $515 \pm 75$ radiocarbon yr B.P. A similar condition exists in the upper $6 \mathrm{ft}(1.8 \mathrm{~m})$ of nearby borehole KA4B: an age of $145 \pm 75$ radiocarbon yr B.P. was obtained for a sample at 3.1 f $(0.95 \mathrm{~m})$ midway in the surface(?) peat layer, and an age of $510 \pm 70$ radiocarbon yr B.P. was obtained at the base of a peat at $5.8 \mathrm{ft}(1.77 \mathrm{~m})$. The peat at $5.8 \mathrm{ft}$ may be the bottom of the surface organic layer or may be overlain by an unsampled silt layer.

No buried peat layers are present below surface peats in boreholes KA4 and KA4B. In borehole KA4, organic silt at $24.2 \mathrm{ft}(7.4 \mathrm{~m})$ gives an AMS radiocarbon age of $4,533 \pm 84$ yr B.P. In borehole KA4B, organic silt at $12.7 \mathrm{ft}(3.9 \mathrm{~m})$ gives a conventional radiocarbon age of $9,255 \pm 420 \mathrm{yr}$ B.P. Buried peat layers are present in a nearby tidal-channel section at depths of about 12 and $25 \mathrm{ft}(3.7$ and $7.6 \mathrm{~m})$ and yield ages of $1,595 \pm .75$ and $3,270 \pm 90$ radiocarbon yr B.P., respectively (BartschWinkler and Schmoll, 1984b).

The lack of complete correlation of buried peat layers among adjacent sites in the same estuary illustrates one difficulty of using borehole drilling for paleoseismicity studies: buried coastal-marsh peats are not continuous. The most likely explanations for this lack of continuity are (1) some sites were in a subtidal or lower intertidal environment where no surface peat existed at the time of subsidence, and (2) some pents may have been removed by post-seismic tidal-channel erosion and replaced by tidal muds.

\section{COMPARISON WITH PREVIOUS DATA}

A comparison of radiocarbon ages from boreholes drilled in 1988 at Girdwood and Portage with data obtained at the same locations in 1985 (Combellick, 1986) shows some close agreement and some serious disagreement between the data sets (fig. 10). Some peat layers that appear at the same depth in adjacent boreholes correlate closely in age, but orhers disagree by several multiples of their laboratory standard deviations. For example, reported ages of the peat layer at about $25-\mathrm{ft}$ (7.6 m) depth in adjacent Girdwood boreholes differ by only 90 radiocarbon $y r$, well within the \pm 10 range of both samples. In contrast, the reported $1,935 \pm 150 \mathrm{yr}$ age of peat at about $10 \mathrm{ft}(3 \mathrm{~m})$ in the 1985 borehole is clearly inconsistent with the much younger reported ages 

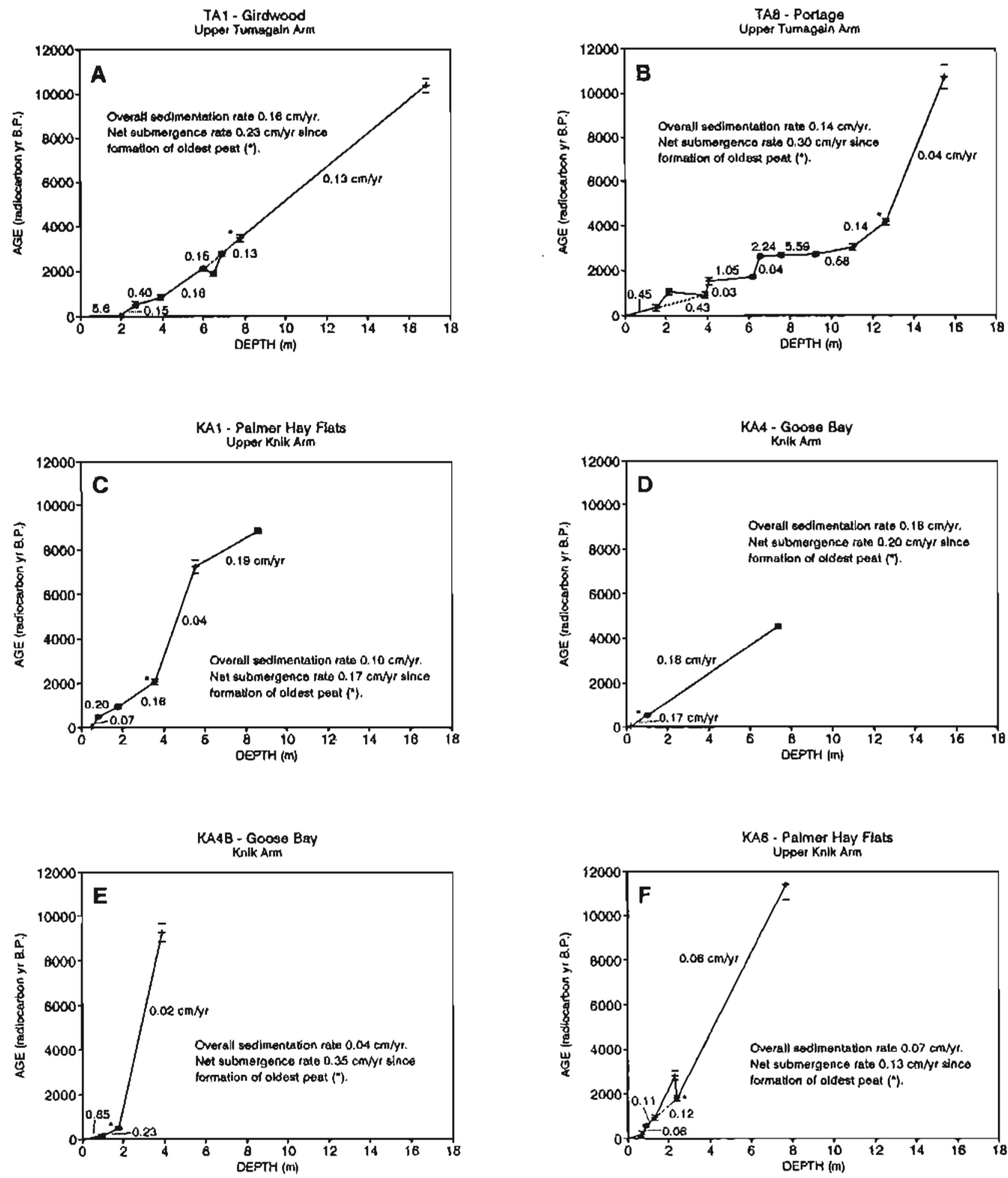

Figure 9. Plots of radiocarbon age versus depth for six boreholes in the vicinities of upper Turnagain and Knik Arns (data from table 2). Crosses (+) indicate age and bars (-) delimil laboratory standard deviation. Sedimentation rates given in cm/radiocarbon yr. Broken lines denote sedimemation rates spanning periods of quesrionable radiocarbon age. 
$(510 \pm 130$ and $815 \pm 115 \mathrm{yr})$ of peats that appear slightly above and below it in the adjacent 1988 borehole. Similar discrepancies exist between adjacent boreholes at Portage, although peats at $30.3 \mathrm{ft}$ and $41.5 \mathrm{ft}(9.2$ and $12.7 \mathrm{~m}$ ) correlate closely (fig. 10).

Peat at 10-ft $(3-\mathrm{m})$ depth in the 1985 and 1988 Girdwood boreboles is at about the same level (taking into account earthquake subsidence in 1964) as a peat layer dated by Karlstrom (1964) at $700 \pm 250$ radiccarbon yr B.P. This relation supports the validity of the 510 - and 815 -yr ages in the 1988 borehole and suggests that the 1,935-yr age in the 1985 borehole may be erroneous. Bartsch-Winkler and Schmoll (1987) obtained a radiocarbon age of $1,840 \pm 50 \mathrm{yr}$ B.P. for a peat sample collected by auger at a depth of about $22 \mathrm{ft}(6.7 \mathrm{~m})$ below the surface in the middle intertidal zone at Girdwood. This peat may correlate with one of the layers in the 20- to $23-\mathrm{ft}(6.1$ to $7.0-\mathrm{m})$ depth range in Girdwood boreholes TA-B1 and TA1, but the correlation does not clearly resolve the age discrepancies at that depth (fig. 10).

Until additional data are obtained at the Girdwood and Portage sites, the remaining age discrepancies may remain unresolved. Possible reasons for the discrepancies include (1) stratigraphic discontinuities between adjacent boreholes; (2) labeling errors; (3) contamination by external organic matter or bacterial activity; (4) handling errors in the laboratory; or (5) analytical errors arising from faulty equipment, poor technique, or calibration problems.

Tidal or fluvial channel migration disrupts stratigraphic continuity and is evident in many other boreholes in the area. However, channel deposits observed in other boreholes are much coarser than the host tidal deposits and are devoid of peat layers. Laboratory orrors seem highly unlikely considering that both sets of samples were analyzed at the same reputable laboratory.

Several months elapsed before subsamples from the 1988 cores could be submitted for radiocarbon dating, so contamination by bacterial activity is a possible source of error. Bacterial uptake of recent carbon dioxide is known to be responsible for anomalously young radiocarbon ages in marine cores stored unfrozen for several years in unsealed core boxes. Geyh and others (1974) showed that the effects of bacterial contamination become more pronounced with age of the sediment, producing highly erratic results on samples of Pleistocene age (more than $10,000 \mathrm{yr}$ old). In all cases, contamination results in a radiocarbon age that is younger than expected. Severely contaminated samples of Holocene age can be in error by up to 2,500 radiocarbon $\mathrm{yr}$.
Unlike the results documented by Geyh and otbers (1974), results of this study at Girdwood and Portage show the greatest discrepancies in the youngest samples $(<3,000$ radiocarbon yr B.P.). And, although most of the apparent discrepancies in 1988 samples are due to radiocarbon ages that are younger than expected, some ages are older than expected. Other radiocarbon ages, particularly for older samples, show close agreement with the 1985 results.

Regardless of sources of error, until a sufficiently large regional data base exists, these discrepancies may weaken the significance of exact ages of peat layers for construcking a history of events. To avoid confusion and for the sake of consistency, the remaining discussion on sedimentation rates, subsidence, and earthquake implications is limited to data obtained from 1988 and 1989 boreholes. All radiocarbon dating of these samples was performed at the same laboratory at about the same time, which should eliminate any significant effect of differences in laboratory methods or should cause any systematic errors to be uniform.

\section{DISCUSSION}

\section{PALEOSEISMICITY}

Many of the peat layers that were observed in borehole samples in this study exhibit stratigraphic evidence of gradual shoaling, vegetation growth, and peat development. followed by rapid submergence and burial below present high-tide level. This stratigraphic evidence supports the hypothesis that each buried peat layer represents a vegetated supratidal surface that subsided during a major earthquake. Burial occurred rapidly as new sediment was deposited on the submerged flat, probably in much the same why that sedimentation in upper Tumagain Arm restored the flat to subaerial conditions within 17 yr following the 1964 earthquake (Kachadoorian and Ovenshine, 1984).

None of the borehole samples exhibit conclusive evidence of major ground shaking associated with peat submergence and burial. Liquefaction features like sand dikes crossing peat layers and sand-blow deposits directly overlying peat layers are the moss conclusive forms of evidence of major around shaking observahle in cross section. Probability is low that these fiquefaction feapures will be encountered or recognized in borehole drilling.

It may be argued that the observed stratigraphic relationships are consistent with burial of the peats by river-flood deposits, followed by submergence. 


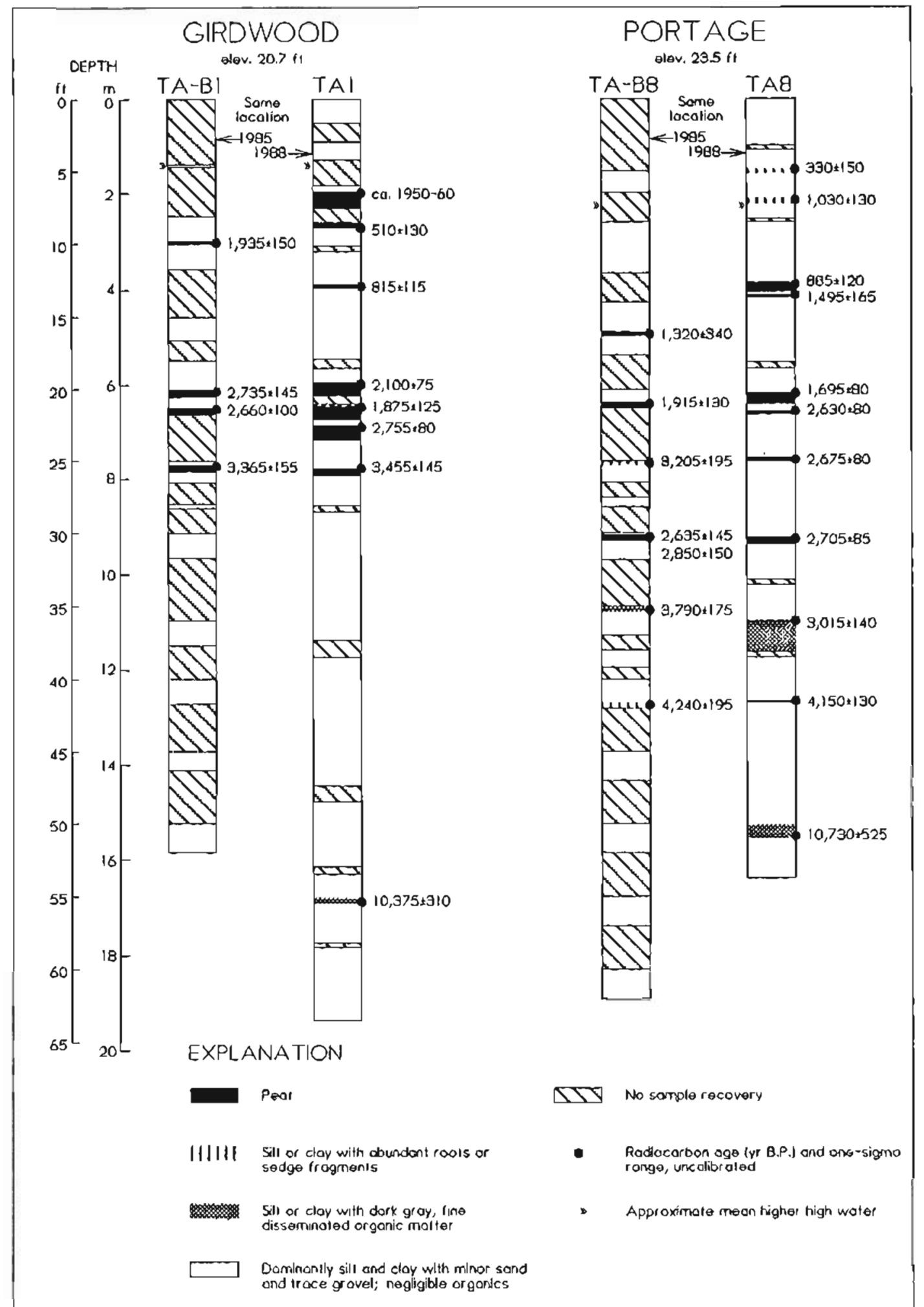

Figure 10. Comparison between radiocarbon ages of samples from boreholes drilled at adjacen locations near Girdwood and Pontage in 1985 and 1988. See iables 1 and 2 for laboratory numbers. 
However, with exception of the peat layer at $19.7 \mathrm{ft}$ $(6.0 \mathrm{~m})$ in $\mathrm{TAl}$, which is overlain by pebbly coarse sand, no significant textural differences are evident in deposits overlying buried peats to indicate a change from tidal to fluvial sedimentation.

Gradual submergence by aseismic subsidence can be ruled out as a model for formation and burial of peat layers because long stillstands would be necessary for peat to form. Also, gradual submergence would subject the surface to erosion and reworking by storm waves and tidal currents, making preservation of peats less likely. Dragging of large ice masses by tidal currents during winter in Turnagain and Knik Arms is particularly destructive.

Rise of regional sea level during the late Holocene (Clark and others, 1978) provides favorable conditions for preservation of coastal-marsh deposits. However, the observed peat-silt couplets could not result from a rise at uniform rate. Intermittent sea-level rises could produce an alternating peat-silt sequence, but these rises are not likely to be large and sudden enough to produce sharp upper peat contacts and organic-poor overlying sediment. Repeated sudden tectonic lowering followed by intertidal silt deposition seems the most likely mechanism for rapidly burying coastal-marsh peats with organic-poor silts.

Radiocarbon dating of organic material at the tops of submerged peat layers provides maximum ages for subsidence events. If fluvial-flood deposition buried the vegetation before it was submerged, an unknown period of time passed between the vegetation growth and its submergence. If burial was due to rapid marine deposition after submergence, the radiocarbon age provides a close maximum age for the event. Lack of textural changes above the peats suggests that burial was by renewed. intertidal deposition following submergence rather than by fluvial flooding. In either case, assuming the hypothesis relating submerged peat layers to major earthquakes is correct, then the pents provide a rainimum count of earthquakes that have occurred following deposition of the oldest peat. As previously discussed, apparent age discrepancies make attempts at assigning ages to all late-Holocene earthquakes risky at this time.

Regardless of exact timing, the number of buried peats in a borehole can be considered a minimum count of subsidence events during the period in which they were deposited because additional events may have occurred for which no peat layer was preserved. Tiual deposition may not have restored the flat at a particular site to subaerial conditions before every earthquake. As BartschWinkler and Schmoll (1987) have shown, vegetated and nonvegetated zones of the tidal area migrate seaward and landward over time, so preservation of peat layers representing all subsidence events at any one location is highly unlikely.

Borehole TA8 at Portage showed the largest number of buried peat layers. Of eight layers preseat, six are well-developed peats $>1$ in. $(2.5 \mathrm{~cm})$ thick and two are thin $(<0.5 \mathrm{in}$. or $1.3 \mathrm{~cm})$ peat seams. The two thin peat seams do not necessarily represent former supratidal surfaces. Therefore, the Portage site shows evidence of six to eight subsidence events during about the last 4,200 radiocarbon yr (about 4,700 calendar yr)(table 2) before 1964. This rate translates to a maximum average recurrence interval of 525 to $700 \mathrm{yr}$ (very roughly 590 to $780 \mathrm{yr}$ if calculated on the basis of tree-ring calibrated ages from table 2).

Assuming radiocarbon ages of peats at $T A 8$ are valid and the interpretation that they represent subsidence during major earthquakes is correct, the data suggest there were three major (great?) earthquakes within a period of less than $100 \mathrm{yr}$ between $2,705 \pm 85$ and $2,630 \pm 80$ radiocarbon $y$.a. If calibrated ages are used, the minimum time span is only 33 yr plus laboratory standard deviations (table 2).

Occurrence of three large earthquakes within 100 yr appears inconsistent with the long-term average recurrence interval and contradictory to seismic-gap theory. This theory states that a region along an active plate boundary that has not produced a large earthquake for a long time is more likely to be the site of a future large earthquake than adjacent regions that have ruptured more recently (McCann and others, 1979). The theory implies that after a gap-filling earthquake, sufficient time must elapse before stresses can reaccumulate for release in another large earthquake. Seismologists have successfully used the seismic-gap theory to forecast large earthquakes, including the October 17, 1989, Loma Prieta, Califomia, earthquake (Ward and Page, 1989).

Multiple large earthquakes have occurred in the same rupture zone within an unusualiy short period. For example, the May 7, 1986, great earthquake ( $\mathrm{Mw}=8.0$ ) in the Andreanof Islands of the Aleutian Archipelago, Alaska, occurred in approximately the same location as a great earthquake on Marcb 9, $1957(\mathrm{Mw}=8.6)$. The a ftershock zone of the 1986 event overlapped a significant portion of the 1957 rupture zone (Ekström and Engdahl, 1989). The time between these events was only $29 \mathrm{yr}$, even though the recurrence period had been projected at $249 \mathrm{yr}$ on the basis of a time-predictable probabilistic model (Jacob, 1984). Submergence and burial of three well-developed peats with radiocarbon ages spanning less than 100 yr at Portage may be evidence of similar, 
unusually brief recurrence times for multiple large earthquakes in the 1964 rupture zone about 2,700 radiocarbon yr ago.

It is not possible with any degree of confidence to relate apparent amounts of subsidence between peat layers to earthquake magnitudes. Inferences could be made about relative magnitude only if reliable regional data were available to document the areal distribution of deformations associated with individual events. For example, differences in depth between peat layers at Portage (borehole TA8) cannot be used to infer differences in earthquake magnitude because the position of this borehole relative to the zero isobase of deformation is not known for each event. During the 1964 event, vertical displacements varied considerably over relatively short distances (Plafker, 1969). The position of the zero isobase and the distribution of vertical deformation undoubtedly is not the same in every large earthquake along this rupture zone. Therefore, the amount of subsidence at Portage could vary substantially during successive earthquakes of similar magnitude.

Perhaps all that can be ssid about magnitude of prehistoric earthquakes based on available data for this region is that a large-magnitude event is necessary to produce subsidence or uplift that is likely to be preserved in the geologic record. The relation of length of deformation zone to earthquake magnitude for historic subduction-zone events along the Pacific margin suggests a threshold of about magnitude 7, below which measurable permanent crustal deformation does not occur (West and McCrumb, 1988). A higher threshold is probably necessary for deformation to be preserved as uplifted marine terraces or submerged supratidal peat layers.

Available daca from this and other studies of coseismic upliff and subsidence in the rupture zone of the 1964 great Alaskan earthquake provide strong evidence that several major events occurred during the past 5,000 yr. However, insufficient regional data are available to construct a credible, complete timetable of events. Comparison of data from this sndy with data from some other studies in the region shows little obvious correlation of radiocarbon ages that are presumably associated with coseismic uplift or subsidence (fig. 11). As discussed above, data from this study in upper Turnagain Arm, from both 1985 and 1988 boreholes, strongly suggest at least one and possibly three events between 2,600 and 2,900 radiocarbon yr B.P. However, radiocarton ages of these peats do not correlale with reported ages from other areas, except for a discordant age of a poorly developed peat in borehole KA6 in upper Knik Arm (2,810 $200 \mathrm{yr}$; not plotted an fig. 11). Either there are major errors in radiocarbon ages in this or other studies, or burial events were restricted to Turnagain Arm and not associated with large interplate earthquakes, or evidence of the earthquakes has not been discovered in the other areas.

Comparison of data from this study at Portage with data at Miduleton Island (Plafker and Rubin, 1978) suggests possible correlation of events at about 1,300-1,500, 3,800 , and 4,100-4,400 radiocatton yr (fig. 11). There also may be regional evidence of events at about $700-1,000,1,700-2,100$, and 3,100-3,400 radiocarbon yr. Close correlation between the ages of a buried peat layer at $P$. Woronzof (Bartsch-Winkler and Schmoll, 1984b) and an uplifted terrace at Middleton Island suggest another passible event at about 2,300-2,400 radiocarbon yr B.P. Considering discrepancies in raliocarbon ages that have been discussed previously, these corretations are highly speculative.

Although radiocarbon ages were obtuined for some near-surface peats where sample recovery was incomplete, their meaning with regard to recent subsidence history and earthquake occurrence is obscure because their stratigraphic context is unclear at all locations except KA6 and KA7 on Palmer Hay Flats. Shallow peat layers dating at about 500 radiocarbon yr B.P. at locations TA1, KA1, KA4, and KA4B all appear below sampio breaks that could contain either continuous peat or interbeds of tidal sediments. These breaks in sample continuity occurred where the coring device did not retain soft, wet peat and sediment in the shallow subsurface benenth the frozen ground. If peat is continuous between the 500-yr layer and the surface (or between the 500 -yr layer and the pre-1964 peat at TAl), $500 \mathrm{yr}$ is a basal age that represents the onsel of vegetation on the pre1964 supratidal flat and is a minimum age for the most recent mijor pre-\$964 earthquake. If the peat is buried beneath tidal silt, $500 \mathrm{yr}$ (calibrated age about 530 calendar yr) (table 2) is a close maximum age for that event.

At KA6, a peat layer with a radiocarbon age of $560 \pm 70 \mathrm{yr}$ is overlain by $3 \mathrm{ft}(0.9 \mathrm{~m})$ of silty ciay and organic silt to the surface of the supratidal flat. At KA7, a peat kayer with a radiocarbon age of $495 \pm 120 \mathrm{yr}$ is overlain by $3.5 \mathrm{ft}(1.1 \mathrm{~m})$ of silt. At both locations, the 500-yr peat layer is above present MHHW, but still below the level of most high spring tides. Although burial may have resulted from regional subsidence, the possibility of burial during a major flood of either Matanuska or Knik Rivers must also be considered. Glacial-outburst flooding occurred al most annually in Knik River between 1918 and 1966 and could be a mechanism for sedimentation on Palmer Hay Flats during a major flood. However, the very fine-grained texture of the deposits overlying the peat is inconsistent with major fluvial-flood deposition 
except possibly in very quiet back-water conditions. The ages of these peat layers correlate closely with submerged peats at four other locations in Tumagain and Knik Arms. This correlation strongly suggests a regional subsidence event that was probably associated with the youngest pre1964 major earthquake, at or before about $500 \mathrm{y}$, a.

\section{SEDIMENTATION AND SUBMERGENCE RATES}

From the 1988-89 data, average net sedimentation rates were coroputed both for intervals between radiocarbon-dated layers and for each borehole section between the oldest dated layer and the surface (fig. 9). If the model for restoration of Portage Flats after the 1964 earthquake (Kachadoorian and Ovenshine, 1984) is correct for previous subsidence events, actual sedimentation rates are not constant between events. Rates are very high immediately after an event, tapering to very low or zero for most of the remaining time before the next event. Consequently, reported sedimentation rates between dated layers represent the average rates over periods during which actual rates may have varied considerably. Additionally, the calculated rates represent net effects of sedimentation, compaction, and possible erosion.

At location TA1 (Girdwood), the data suggest an overall rate of $0.16 \mathrm{~cm} / \mathrm{yr}$ for about the past 10,400 radjocarbon yr. With exception of the anomaly caused by the outher at $21.2 \mathrm{ft}(6.5 \mathrm{~m})$ (fig. 9, A), the net rate remained relatively constant between 0.13 and $0.40 \mathrm{~cm} / \mathrm{yr}$ prior to 1964.

At location TA8 (Portage), the data suggest a similar average sedimentation rate of $0.14 \mathrm{~cm} / \mathrm{yr}$ for the past 10,730 radiocarbon yr. However, this rate is based on a questionable age for the oldest dated sample and is considerably slower than the rate determined by BartschWinkler and others (1983) at a nearby borehole. If the rate is computed from the oldest, presumably reliably dated peat at this location $\langle 4,150 \pm 130$ yr B.P. at $41.5 \mathrm{ft}$ or $12.7 \mathrm{~m}$ ), the long-term sedimentation rate would be $0.30 \mathrm{~cm} / \mathrm{yr}$. This rate compares favorably with the 0.25 $\mathrm{cm}$ rate determined by Bartsch-Winkler and others (1983) for the past 5,740 radiocarbon yr.

Aside from the possible error in the 10,730-yc age, the remaining radiocarbon ages in borehole TA8 suggest that sedimentation rates at this site were more variable than at TAI (fig. 9, B). In particular, the narrow age span of three peat layers between 9.2 and $6.5 \mathrm{~m}$ suggests sedimentation rates of 0.58 to $5.59 \mathrm{~cm} / \mathrm{yr}$, up to 40 times the long-term rate, between 3,015 140 and
$2,630 \pm 80$ radiocarbon yr B.P. Higher sedimentation rates during this period may have resulted from increased glacial activity during the Neoglacial maximum, which was under way in southern Alaska by about $3,000 \mathrm{y}$.a. and began to recede by about $2,000 \mathrm{y}$.a. (Calkin, 1988). Proximity of the Portage site to several large glaciers could explain why sedimentation rates were much higher there than at Girdwood during this period, even though both sites remained dominantly intertidal (based on lack of significant differences in texture between boreholes or above and below the peat layers in this time span). However, considering discrepancies in radiocarbon ages between the 1985 and 1988 boreholes at Portage, these variations in sedimentation rate may also be an artifact of dating errors.

Long-term sedinentation rates on Palner Hay Flats in upper Knik Arm, represented by boreholes KAl and KA6 (figs. 9, C and F), appear to be about half of the rate computed for Portage and Girdwood in upper Turnagain Arm. At Goose Bay, the long-term sedimentation rate indicated by radiocarbon dates at KA4 is similar to the Turnagain Arm rale $(0.16 \mathrm{~cm} / \mathrm{yr})$, but the rate at horehole $\mathrm{KA} 4 \mathrm{~B}$ is significantly lower $\langle 0.04 \mathrm{~cm} / \mathrm{yr}\rangle$. Considering the proximity of the Goose Bay boreholes on the same supratidal surface (fig. 4), the sedimentation rate should be nearly the same. Most likely, either the 4,533-yr date in KA4 or the 9,255-yr date in KA4B is in error.

Assuming tidal sedimentation and postseismic rebound restore (ivlal flats to subaerial conditions between deposition of peat layers, the average sedimentation rate between peat layers is a measure of the net rate of submergence. Sedimentation rates calculated from dating of the oldest peat layers suggest a net rate of submergence of $0.23100 .30 \mathrm{~cm} / \mathrm{yr}$ in upper Tumagain A rm for the past 3,400 to 4,200 radiocarbon $\mathrm{yr}_{\mathrm{r}}$ and $0.13 \mathrm{kn} 0.17 \mathrm{~cm} / \mathrm{yr}$ in upper Knik Arm for the past I,800 to 2,300 radiocarbon ys. The lower submergence rate for upper Knik Arm appears consistent with measurements following the 1964 earthquake. As a result of the earthquake, Palmer Hay Flats subsided about 2 n (0.6 $\mathrm{m}$ ) (Plafker, 1969), compared to about $5 \mathrm{ft}(1.5 \mathrm{~m})$ of net subsidence in upper Turnagain Arm, taking into account postseismic uplift (Brown and others, 1977).

\section{SUMMARY AND CONCLUSIONS}

A record of prehisturic subsidence events, possibly associated with 1964-style major earthquakes, is preserved in estuarine sediments of Turnagain and Knik Arms in upper Cook Inlet. Multiple peat layers, submerged helow present high-tide levels and buried beneath 

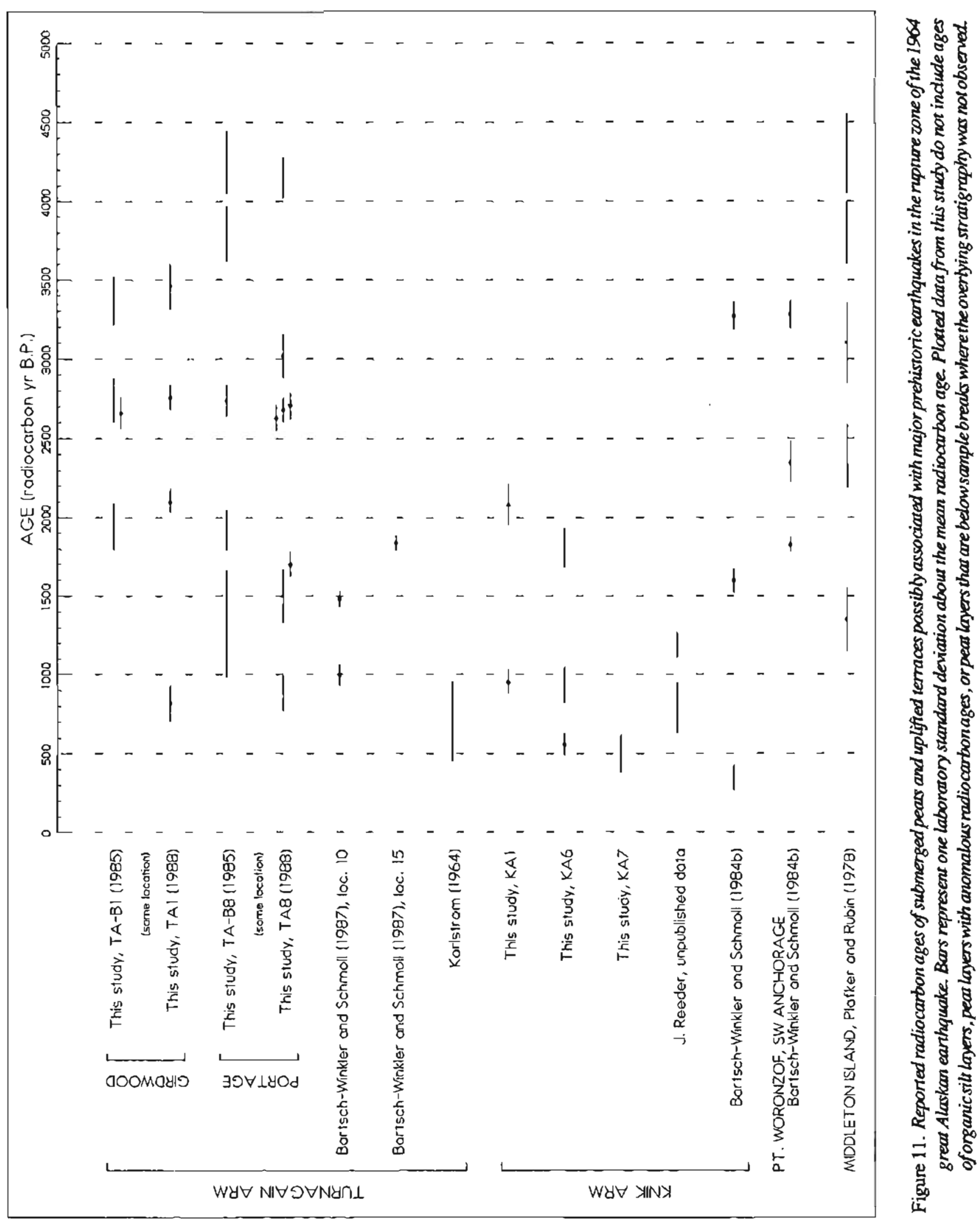
intertidal silt and clay, record cycles of supratidal vegetstion growth, subsidence, and rapid burial during the past 5,000 yr. Radiocarbon dating of organic material at the tops of these peat layers provides maximum ages for subsidence events responsible for their burial and allows calculation of long-term submergence rates. Although uncertainties in some radiocarbon ages preclude accurate dating of all events, the buried peats provide a minimum count of subsidence events from which a maximum average recurrence interval can be calculated.

None of the borehole samples exhibit conclusive evidence, such as liquefaction features, to prove that major ground shaking was associated with peat submergence and burial. However, the sharp upper contacts of many peat layers and the organic-poor nature of overlying muds are probably the result of rapid subsidence during major earthquakes.

Borebole TA8, at Portage, revealed the largest number of buried peat layers among all boreholes drilled in this study. These buried peats are evidence of six to eight subsidence events during about the past 4,200 radiocarbon yr $(4,700$ calendar yr) before the 1964 great Alaska earthquake. This rate transiates to a maximum average recurrence interval of 52510700 radiocarbon yr (about 590 to 780 calendar yr if calculated on the basis of tree-ring calibrated ages). Radiocarbon ages of shallow submerged peat layers in both Turnagain and Knik Arms indicate that the most recent major subsidence event prior to the 1964 earthquake was at or before about 500 y.\&. These conclusions are reasonably consistent with data from the Copper River Delta and Prince William Sound regions (Plafker and others, 1990) that suggest an average recurrence interval of $600-950 \mathrm{yr}$ and about $800 \mathrm{yr}$ since the youngest major pre-1964 earthquake.

At Portage, possible ovidence of three earthquakes within $100 \mathrm{yr}$, between $2,705 \pm 85$ and $2,630 \pm 80$ radiocarbon yr B.P. suggests that, although average recurrence times are on the order of centuries, actual recurrence times may have been as short as several decades. However, because of uncertainties in some of the radiocarbon ages, this conclusion is tentative until more regional data on events during this period are available.

Comparison with radiocarbon ages of other feanures interpreted to represent coseismic subsidence or uplift does not yet provide a clear chronology of pre-1964 events in the region affected by tectonic deformation chring the 1964 earthquake. Although some ages roughly correlate, many do not. This poor correlation of regional data may relate to inaccuracies in radiocarbon dating, to local effects not associated with widespread tectonic changes during major earthquakes, or to combination of these factors.

Assuming the peats developed in high-intertidal or slightly supratidal marshes, sedimentation rates computed from radiocarbon ages of the buried peats provide an estimate of the net rate of submergence. The data indicate net submergence rates of 0.23 to $0.30 \mathrm{~cm} / \mathrm{yr}$ in upper Turnagain Arm for the past 4,200 radiocarbon yr and 0.13 to $0.17 \mathrm{~cm} / \mathrm{yr}$ is upper Knik Arm for the past 2,100 radiocarbon yr.

\section{ACKNOWLEDGMENTS}

The U.S. Geological Survey, Department of the Interior, provided partial fuading for this study under National Earthquake Hazards Reduction Program award 14-08-0001-G1582. The Alaska Department of Transportation and Public Facilities (DOTPF) provided and operated the drill rigs used for all borehole drilling. I especially thank Dan Pavey of DOTPF, who arranged for equipment and organized field logistics, and drillers Paul Mitchell and Les Lee for their expert work under adverse winter conditions. Geochron Laboratories Division, Krueger Enterprises, Inc., performed all radiocarbon-age determinations. I thank Richard Reger for his participation in field work and data interpretation, Bret Davidson for assistance in the laboratory, and Roger Allely for surveying borebole elevations. Thanks also to Alan Batten and Barbara Murray of the University of Alaska Museum for identifying plant remains in the peat samples. Richard Reger thoroughly reviewed the manuscript and provided many valuable suggestions for improvement.

The contents of this report were developed under a grant from the U.S. Geological Survey, Department of the Interior. However, these contents do not necessarily represent the policy of that agency, and you should not assume endorsement by the federal government. 


\section{REFERENCES CITED}

Atwater, B.F., 1987, Evidence for great Holocene earthquakes along the outer coast of Washington state: Science, v. 236, p. 942-944.

Bartscb-Winkler, S.R., and Garrow, H.C., 1982, Depositional system approaching maturity at Portage Flats, in Coonrad, W.L., ed., The U.S. Geological Survey in Alaska: Accomplishments during 1980: U.S. Geological Survey Circular 844, p. 115-117.

Bartsch-Winkler, Susan, and Schmoll, H.R., 1984a, Guide to late Pleistocene and Holocene deposits of Turnagain Arm: Anchorage, Alaska Geological Society, 70 p., 1:63,360, 2 sheets.

1984b, Bedding types in Holocene tidal channel sequences, Knik Arm, upper Cook Inlet, Alaska: Joumal of Sedimentary Petrology, v. 54, no. 4, p. 1239-1250.

1987, Earthquake-caused sedimentary couplets in the upper Cook lnlet region, in Hamilton, T.D., and Galloway, J.P., eds., Geologic Studies in Alaska by the U.S. Geological Survey during 1986: U.S. Geological Survey Circular 998, p. $92-95$.

Bartsch-Winkler, Susan, Ovenshine, A.T., and Kachadoorian, Reuben, 1983, Holocene history of the estuarine area surrounding Portage, Alaska as recorded in a 93 m core: Canadian Joumal of Earth Sciences, v. 20 , no. 5 , p. $802-820$.

Brown, L.D., Reilinger, R.E., Holdahl, S.R., and Balazs, E. I., 1977, Postseismic crustal uplift near Anchorage, Alaska: Joumal of Geophysical Research, v. 82, no. 23, p. 3369-3378.

Calkin, P.E., 1988, Holocene glaciation of Alaska (and adjoining Yukon Territory, Canada): Quatemary Science Reviews, v. 7, no. 2, p. 159-184.

Clark, J.A., Farrell, W.E., and Peltier, W.R., 1978, Global cbanges in postglacial sea level: A numerical calculation: Quaternary Research, v. 9, p. 265-287.

Combellick, R.A., 1986, Chronology of late-Holocene earthquakes in southcentral Alaska: Evidence from buried organic soils in upper Tumagain Arm: Geological Society of America Abstracts with Programs, v. 18, no. 6, p. 569.

1990. Evidence for episodic late-Holocene subsidence in estuarine deposits near Anchorage, Alaska: Basis for determining recurrence intervals of major earthquakes: Alaska Division of Geological and Geophysical Surveys Public-data File 90-29, $67 \mathrm{p}$.
Ekström, Gōran, and Engdabl, E.R., 1989, Earthquake source parameters and stress distribution in the Adak Island region of the ceniral Aleutian Islands, Alaska: Journal of Geophysical Research, v. 94, no. B11, p. 15499-15519.

Foster, H.L., and Karlstrom, T.N.V., 1967, Ground breakage and associated effects in the Cook Inlet ared, Alaska, resulting from the Marcb 27, 1964, earthquake: U.S. Geological Survey Professional Paper 543-F, 28 p.

Friedman, G.M., and Johnson, K.G., 1982, Exercises in sedimentology: New York, John Wiley \& Sons, $208 \mathrm{p}$.

Geyh, M.A., Krumbein, W.E., and Kudrass, H.R., 1974, Unreliable radiocarbon dating of loog-stored deep-sea sediments due to bacterial activity: Marine Geology, v. 17, p. M45-M50.

Jacob, K.H., 1984, Estimates of long-term probabilities for future great earthquakes in the Aleutians: Geophysical Research Letters, v. 11, no. 4, p. 295-298.

Kachadoorian, Reuben, and Ovenshine, A.T., 1984, Natural restoration from the effects of the 1964 earthquake at Portage, southern Alaska, in Coonrad, W.L., and Elliott, R.L., eds., The United States Geological Survey in Alaska: Accomplishments during 1981: U.S. Geological Survey Circular 868 , p. $109-110$.

Karlstrom, T.N.V., 1964, Quatemary geology of the Kenai lowland and glacial history of the Cook inlet region, Alaska: U.S. Geological Survey Professional Paper 443, 69 p., 7 sheets.

1965, Resume of the Quaternary geology of the upper Cook Inlet area and Matanuska River Valley, in Péwe, T.L., ed., Guidebook for Field Conference F, VIIth Congress, International Association for Quaternary Research: Central and south-ceotral Alaska: Fairbanks, Alaska Division of Geological and Geophysical Surveys, reprinted 1977, p. 114-14t.

Kromer, B., Rhein, M., Buns, M., Schoch-Fischer, H., Munnich, K.O., Stuiver, M., and Becker, B., 1986, Radiocarbon calibration data for the 6th and 8th millennia BC: Radiocarbon, v. 28, p. 954-960.

Linick, T.W., Suess, H.E., and Becker, B., 1985, La Jolla measurements of radiocarbon in South German Oak tree-ring chronologies: Radiocarbon, v. 27, p. $20-32$.

Linick, T.W., Long, A., Damon, P.E., and Ferguson, C.W., 1986, High-precision radiocarbon dating of Bristlecone Pine from 6554 to 5350 BC: Radiocarbon, v. 28, p. 943-953. 
McCann, W.R., Nishenko, S.P., Sykes, L.R., and Krause, J., 1979, Seismic gaps and plate tectonics: Seismic potential for major plate boundaries: Pure and Applied Geophysics, v. 117, p. 1082-1147.

Ovenshine, A.T., Lawson, D.E., and Bartsch-Winkler, S.R., 1976. The Placer River Silt-An intertidal deposit caused by the 1964 Alaska earthquake: Joumal of Research of the U.S. Geological Survey, v. 4, no. 2, p. 151-162.

Pearson, G.W., and Stuiver, M., 1986, High-precision calibration of the radiocarbon time scale, 500-2500 BC: Radiocarbon, v. 28 , p. $839-862$.

Pearson, G.W., Pilcher, J.R., Baille, M.G., Corbett, D.M., and Qua, F., 1986, High-precision ${ }^{14} \mathrm{C}$ measurement of Irish Oaks to show the natural ${ }^{14} \mathrm{C}$ variations from $A D$ 1840-5210 BC: Radiocarbon, v. 28 , p. 911-934.

Plafker, George, 1969. Tectonics of the March 27, 1964, Alaska earthquake: U.S. Geological Survey Professional Paper 543-I, 74 p., scales 1:2,000,000 and $1: 500,000,2$ sheets.

Plafker, George, Lajoie, K.R., and Rubin, Meyer, 1990, Determining the recurrence intervals of great subduction zone earthquakes in southern Alaska by radiocarbon dating, in Taylor, R.E., Long, Austin, and Kra, Renee, ods., Radiocarbon after four decades: Tucson, Uriversity of Arizona Press, in press.

Plafker, George, and Rubin, Meyer, 1967, Vertical tectonic displacements in south-central Alaska during and prior to the great 1964 earthquake: Joumal of Gensciences, Osaka City University, v. 10 , p. 53-66.

1978, Uplift history and eartbquake recurrence as deduced from marine terraces on Middleton Island, Alaska, in Proceedings of Conference VI, Methodology for Identifying Seismic Gaps and Soon-to-break Gaps, National Earthquake Hazards Reduction Program, 25-27 May, 1978: U.S. Geological Survey Open File Report 78-943, p. 687-721.

Reger, R.D., and Updike, R.G., 1983, Upper Cook Inlet region and the Matanuska Valley, in Péwe, T.L., and Reger, R.D., eds., Guidebook to permafrost and Quaternary geology along the Richardson and Glenn Highways between Fairbanks and Anchorage, Alaska: Alaska Division of Geological and Geophysical Surveys Guidebook 1, p. 185-263, scale $1: 250,000,1$ sheet.

Stuiver, M., Kromer, B., Becker, B., and Ferguson, C.W., 1986, Radiocarbon age calibration back to 13,300 years $B . P$. and the ${ }^{14} \mathrm{C}$ age matching of the German Oak and U S Bristlecone Pine chronologies: Radiocarbon, v. 28, p. 969-979.
Stuiver, M., and Pearson, G.W., 1986, High-precision calibration of radiocarbon time scale, AD 1950-500 BC: Radiocarbon, v. 28, p. 805-838.

Stuiver, M., and Reimer, P.J., 1986, A computer program for radiocarbon age calibration: Radiocarbon, v. $28, \mathrm{p}, 1022-1030$.

U.S. Department of Commerce, 1988, Tide tables 1989 , west coast of North and South America: Rockville, Maryland, National Ocean Survey, 222 p.

Ward, P.L., and Page, R.A., 1989, The Loma Prieta earthquake of October 17, 1989: Earthquakes \& Volcanoes, v. 21, no. 6, p. 215-246.

West, D.O., and McCrumb, D.R., 1988, Coastal uplift in Oregon and Washington and the nature of Cascadia subduction-zone tectonics: Geology, v. 16, no. 2, p. $169-172$. 


\section{APPENDIX A}

\section{DESCRIPTIONS OF CORE SAMPLES}

BOREFIOLE TA1, GIRDWOOD - 60"56'39"N, 149 $10^{\circ} 35^{\prime \prime}$ W; surface elevation $20.7 \mathrm{ft} \mathrm{MSL}$

Sample

TAl-1

TA1-2

TA1-3C

TA1B-1

$6.0-6.75$

TAIB-1C

7.4-7.6

$7.6-8.5$

$T A \backslash-4 A$

$8.5-8.85$

$8.85-10.1$

$10.1-10.5$

TA1-4B

10.5-11.0

TA1-5

$11.0-11.4$

$11.4-11.8$

\section{Description}

Silty, gravelly sand, very poorly sored, nonstratified (partially disturbed during spliting bccause of large pebbles). Brownish gray to grayish brown. Fill.

Not recovered.

Brownish gray, poorly sorted silty, gravelly sand.

Dark brown to brownish gray siky, gravelly sand with abundant organics, including disscminated clsarcoal, roollets, and one wood fragment.

Gray to brownish gray, poorly sorted silty, sandy gravel, pebbles to $1 \mathrm{in.}$

Entire sample (TA1-2) probabiy fill.

Not recovered.

Gray, poorly sortud, silty, gravclly sand.

Gray silty fine sand with some organies (scdge blades).

Brown sedge peat.

Spl TA1-3-6.4 at top of peat layer, 6.35-6.45 (C) 4).

Dark brown woody peat with abundant roots and twigs. Upper contact sharp along dark band.

Same as 6.5-7.2 (carcher sample; bagged).

(attempted resample of missed interval 7.4-8.5 ft depth, $5 \mathrm{ft} \mathrm{SE}$ of TA1)

Gray very prorly sorted silt, sand, and gravel. Large rounded pebble at top, 0.2 in. diamcier. Pebbles very angular to subrounded, mostly angular. Sharp lower conlact. Possibly fill.

Brown to dark brown fibrous peat with abundant roots and twigs. Lighter colorcd grassy layer in top $0.1 \mathrm{in.}$ (sedge peat).

Pcat as above (catcher sample; bagged).

Nol recovered.

Dark brown woody peat; abundant twigs and rools. Spl TA1-4A-8.8 basal peal, 8.75-8.85 (C14).

Interlsyered gray to brownish-gray silty fine sand and sandy sill. Pincly laminatod between 9.2 and bottom. Laminations are horizontal and less than 1/8 in. thick. A brownish rind exists about $1 / 4$ in. thick along sample margins, possibly from ironrich water penctrating along edges during sumpling. Laminations are visible in rind, so rind is not duc to disturbance during sampling.

Not recoverod.

Massive gray silt; one $1 / 2$ in. diameter lwig, probably transported.

Brownish-gray silt and finc sand; disturbed, probably by sampling.

Gray silt and fine sand witly contorted, thin, indistinct laminac. 
$11.8-12.75$

TA $1-6 A$

TA $1-6 B$

$15.4-15.8$

$15.8-17.1$

TA1-6C

TA1-7

$18.5 \cdot 18.8$

$18.8-19.3$

TA1-7C

TA1-8

TA1-9A

$23.5 \cdot 23.6$
Gray to brownish gray silt, possibly clay-rich, wjt) scallered lwigs and sedge blades. Foint, thin horizontal laminae $1-4 \mathrm{~mm}$ thick. Twig, 1/2 in. wide, al 12.1; probably transported. Sharp lower contact.

Dark brown to light brown sedge peat. Gradational lower conlact. Spl TA1-5-12.8 at top of peat laycr, $12.75-12.85$ (C14).

Gray and stained (molled) light brown clay and sill with scatlered organics. No visible bedding.

Gray to brownish gray sild line sand with some iron staining along edges. Trace organics.

Gray to brownish gray sild line sand with distinct laminations 1-4 mm, gencrally horizontal and undistumed. Scaltered roots and twigs. Flat picce of wood 1 in. $x$ 1 in. $x 1 / 4$ in. at 15.2, partially charcoal; probably transported.

Disturbed zone (from sampling) of gray sild/bne sand with some iron staining around scattercd organics (roots or sedge blades).

Laminated to thin-bedded gray silt and fine sand with seattered sedge blades or roots. Iron stained around organics.

Laminated gray silt and claycy silt. Trace organics.

Spl TA1-6B-17,1 at 17.0-17.2 (GS).

Dark brownish gray pebbly medium to coarse sand; trace silt. No visible bedding. Pebbles subangular to well rounded.

Pebbly coarse sand. Angular to subrounded pebbles to 1/2 in. diameter (calcher sample; bagged).

Nol recovered

Gray medium to cosrse clean sand, coarsening downward; silt lense at 18.7. A few twigs or rooss at lop surface; 1/4-in. Iwig at 18.65. probably transported.

Gray pebbly cosrse sand with angular to rounded pebbles to $3 / 4$ in. Negligible silt, no visible bedding.

Spl TAl-7-19,0 at 18.9-19.2 (GS).

Gray medium to coarse sand with some small pebbles and negligible silt, coarsenine downward.

Uniform gray claycy silt.

Dark brown woody or sedge peat. Twigs up to $1 / 4 \mathrm{in}$. diarneter. Spl TA1-7-19.7 at 19.65-19.75 (Cl4).

Peat as above (calcher sample; bagged).

Not recovered.

Gray silt, sand, pebbles, and organics. Could be slough from drill stem.

Dark brown layered woody or sedge peat wilh a few thin lenses of gray silt. Spl TA1-8-21.2 of surface peat, 21.1-21.25 (Cl4).

Gray clayey silt with some twigs and rooks.

Dark brown woody peat with minor thin silt layers near top. Lighter brown in upper 3 in.

Spl TA1-8-22.6 of surface peat, 22.5-22.7 (C14).

Mixed silt, sand, and organics; probably dislurbed during sampling. 
23.6-24.3

$24.3-25.4$

$25.4-25.6$

TAI-9B

$25.6-25.9$

$25.9-27.85$

TA1-9C

TA1-10

TA1-11A

$31.0-31.65$

TA1-11B

$31.65-33.8$

TA1-12A

$33.8-34.55$

TA1-12B

$34.55-37.0$

TA1-12C

$37.0-37.25$

$37.25-38.5$

TA1-13A

$38.5-40.75$

TAL $-13 B$

$40.75-41.5$

$41.5-43.25$

TA1-13C

$43.25-43.4$

43.443 .5

TA1-14A

$43.5-44.75$
Layered dack brown sedge peat and gray silt. Possibly gradational base of lower pent in TA1-8.

Massive gray clayey silt moutled with dark gray organic smears, bue organics are nogligible.

Spl TA1-9A-25.3 at 25.2-25.4 (GS).

Dark brown sedge and woody peat.

Spl TA1-9A-25.5 th 25.4-25.6 (Cl4).

Dark brown woody pcat grading downward to brownish gray claycy silt, faintly layeres (base of peat unit at botiom of TA 1-9A).

Brownish gray to gray clayey silt wilh scallerod organics (roots and scodgc blades). Very faint thin laycring. Lower part morled with dark gray organic smears. Spl TA1-9B-26.3 at 26.2-26.4 (GS).

Gray claycy silt (eatcher sample; bagged).

Not recovered.

Brownish gray to gray clayey silt. Very faint thin layering. Iron staining in lower portion concentrated around minor organics. Some dark gray mottling, probably organic smcars.

Gray claycy sill with dark gray organic smcars. Trace scdge blades and minor iron staining along cdges.

Gray to brownish gray clayey sill with tracc organics, minor iron staining, and dark gray organic smcars. Grades to sundicr near boltom; minor small pesbles in lower 3 in.

Spl TA1-11R-33.0 at 32.9-33.1 (GS).

Brownish gray to gray sill and frne sand; no visible bedding, possibly disturbed.

Brownish gray fine sandy silt and clayey silt with pebbly zones. Mot1led with dark silty zoncs. Interlayered dark gray silt and brownish gray silty fine sand 36.3-36.8, laycrs $1 / 2$ to 1 in. thick. All but 36.3-36.8 may be disturbed. No organics. Single angular pebble at 34.8. Pebbly (angular to rounded) and sandy zone 35.4-35.7. Two-inch rounded pcbble at 36.8 .

Spl TA1-12B-36.5 at 36.4-36.6; layered sandy silt and claycy silk (GS).

Coarse silt or silty fine sand (catelier sample; bagged).

Not recovered.

Brownish gray to gray sill and fine sand with minor scallered pebbles. Most pebbles subrounded to well rounded; max. diameter about 1 in. Large (2-1/2 in.) very angular pebble at 40,5 . No visible bedding. Much of this sample may be disturbod, probably during transport.

Disturbed layer of brownish gray silty fine sand.

Interfayered light brown silty line sand and gray fine sandy silt. Some thin bedding and lamination. A few pebbles, including one subrounded pebble 1 in. diameler al 42.6. No organics.

Spl TAI-13B-41.8 at 41.7-41.9, brown sandy silt (GS).

Dense silty linc sand (catcher sample; bagged).

Nol recovered.

Dark gray uniform silly fine sand. No visible bedding. Traec pebbles ( $1 / 2$-in. angular pebble at 44.6). No organics. Could be disturbed (according to drilling log). 
TA1-14B

$44.75-45.3$

$45.3-45.4$

$45.4-46.7$

$46.7-47.2$

TA1-14C

$47.2-47.4$

$47.4-48.5$

TAI-15A

$48.5-50.4$

TAl-15B

$50.4-52.75$

TA1-15C

$52.75-53.0$

$53.0-53.5$

TA1-16

$53.5-53.9$

$53.9-55.9$

TAL $-16 C$

$55.9-56.0$

TAl-17

$56.0-58.0$

TA1-17C

$58.0-58.25$

58.25-58.5

TA1-18A

$58.5-60.6$

TA1-18B

$60.6-62.3$

$62.3-62.4$

62.4-62.7

62.7-63.05

TAl-18C

63.05-63.3
Gray to brownish gray silly fine sand. Slight hint of thin bedding. One rounded pebble $1-3 / 4$ in. long al 44.8 .

Gray clayey silt, uniform.

Grayish brown to gray silt wilh distinct horizontal layering in lower $0.3 \mathrm{f}$. Two pebbles about 2 in. long at 45.9 and 46.2 . Slight grading to medium sand at base. Spl TAl-14B-45.6 at $45.5-45.7$ (GS).

Gray to brownish gray silty fine sand. No visible bedding. Dark gray zone at $46.9-$ 47.1 may be organic-rich (disseminated).

Silly fine sand or coarse silt (catcher samplc; bagged).

Nol recovered.

Brownish gray to gray uniform silty fine sand. Brownish (iron staised) 48.5-48.8. Minor pebbles (rounded, up to $1 / 2$ in.) at 48.6 and 50.0. Trace shell fragments $(48.65,49.9)$.

Gray to brownish gray uniform silty fine sand. Trace shell fragments (e.g. 50.7). Several angular to rounded pebbles to $1 / 2 \mathrm{in}$. at 52.6 .

Dense, vcry finc sand (catcher sample; bagged).

Not rocovered.

Slough from drill stem.

Brownish gray to gray uniform silky line sand or sandy silt. Very laint laycring. One-inch angular pebble at 54.0 (probabiy ice-rafled). Dark gray layers at 55.255.4 , organic-rich(?).

Spl $\mathbf{T 1}-17-55.3$ at $55.2-55.4$, thin taminated charcoal in silty fine sand (C14).

Silky fine sand or sandy sill (calcher sample; bagged).

Brownish gray to gray uniform fine sandy silt. No visible bedding and no organies. Trace scattered small pebbles. Brownish color apparently from iron staining. Sol T11-17-57.0 at 56.9-57.1 (GS).

Sitty fine sand or sandy silt (catcher sample; bagged).

Not recovered.

Brownish gray to gray uniform silly [inc sand with trace scattered small pebbles (probably íce-rafed). No visible bedding or organics. Brownish color from iron staining. Rounded pebble 3/4-inch at 60.4 .

Browrish gray to gray uniform line sandy silt with trace scallered small pebbles (one well-rounded pebble 1/2-in. dia.) al 61.95. No visible bedding. Trace organics (dark gray smciar) al 61.5. Brownish color from iron staining. Spl TAI-18B-61.0 al 60.9-61.1 (GS).

Thin layer of pebbly coarsc sand.

Gray uniform silty fine sand. No visible bedding or organics.

Gray pebbly, silty fine sand; 2 -in. pobble at 63.0 .

Gravel (catcher sample; bagged).

Maximum depth sampled $63.3 \mathrm{ft}$. 
BOREHOLE TA8, PORTAGE $-60^{\circ} 48^{\prime} 54^{n} \mathrm{~N}, 148^{\circ} 57^{\prime} 57^{\prime \prime} \mathrm{W}$; surface elevation $23.5 \mathrm{ft}$ MSL.

Sample

TA8-1

TA8B-1

$1.4-1.6$

$1.6-3.1$

TABB-1C

$3.1-3.2$

3.2-3.5

TA8-2A

3.5-3.9

TA8-2B

$3.9-4.85$

4.85-5.1

$5.1-6.3$

TA8-2C

6.3-6.55

TA8B-2

$6.0-6.4$

6.4-6.9

6.9-7.2

7.2-8.1

TA88-2C

8.1-8.3

8.3-8.5

TA8-3

8.5-10.7

\section{Description}

Gray fine sand mixed with surface organics (leaves, twigs, roots).

Gray to brownish gray, layered silty very fine sand to clean fine or medium sand. Pour layors $0.2100 .6 \mathrm{ft}$ thick, reverse graded (ine al bottom to medium at top). Scattered roots and twigs throughout. Mica rich 1.0-1.6.

Gray uniform fine to modium sand, clean. No bodding; trace organics. Probably Auvial.

Fine to medium sand with trace silt (catcher sample; bagged).

(From adjacent borchoie to resample missed interva) 2.2-3.9; 6 ft NE of TA8)

Disturoed. Gray fine to medium sano with some organics.

Gray to brownish gray, laycred silty very fine sand to clean fine or medium sand. Three layers to 0.6 -in. thick, reverse graded as in TA8-1, 0.3-1.8. Trace organics.

Clean medium sand (catcher sample; bagged).

Not recovered.

Fine sand with some silt and organic smears (bagged).

Gray, uniform, finc to medium sand with minor silt. No visible laycring. Trace organics.

Spl TA8-2R-4.7 at 4.6-4.8 (GS).

Interlayered brownish gray to gray sill, silly line sand, and organics (probably sedge).

Spl TA8-2B-4.9 at 4.85-5.1 (C14); sedge blades, roots, and thizomes(?), probably in place at time of deposition.

Gray silt and silty fine sand with faint laycring and scattesed minor organics.

Silt or silty fine sand (catcher sample; bagged).

(From adjacent borehole to sample missed interval 6.3-8.4 in TA8; 6 \& NE of TA8)

Probabiy disturbed, gray, uniform, clean fine sand; probably fluvial.

Gray silt and siky finc sand wilh fainl laycring. Minor iron staining. Trace organics.

Brownish gray to gray layered sill, silty line sand, and organics (scdge). Iron stained in organic zones. Fluvial(?).

Spl TA8R-2-7.0 at 6.9-7.1 (C14).

Brownish gray to gray silt, silly fine sand, and clean fine sand. Distinct layering (silt layer with sharp contacts at 7.9-8,0). Negligible organics.

Clean fine sand (catcher sampic; bagged).

Nol recovered.

Gray sitty fine sand and clean tine sand will some silk interiaycrs $10.0-10.7$. Faint iron staining. No organics.

Spl TA8-3-9.5 at 9.4-9.6 (GS) 
TA8-3C

$10.7-11.0$

TA8-4

$11.0-11.85$

$11.85-12.6$

$12.6-13.25$

$13.25-13.4$

TA $8-4 C$

TA8-5A

$13.4-13.5$

$13.5-13,6$

$13.6-15.2$

TA8-5B

$15.2 \cdot 17.5$

TA8-5C

TA8-6

TA8-6C

$20.9-21.0$

TA8-7

TA8-7C

TA8-8

$25.0-25.75$

TA8-8C
Fine sand with trace silk (catcher sample; bagged).

Gray silt, silty fine sand, and clean fine sand in contorted zones; probably disturbed during sampling. Some evidence of Jamination at 11.4. Negligible organics. Minor iron staining.

Gray to brownish gray clayey silt and fine sandy sili. Disseminaled organics 12.112.3. Scattered sedge blades.

Spl TA8-4-12.5 at 12.4-12.6 (GS).

Brown to dark brown sedge and woody peat. Increasing silt towa rd base. Sharp upper contact.

Spl TA8-4-12.7 at 12.6-12.75 (C14).

Brownish gray organic-rich silt.

Sedge peat (catcher sample; bagged).

Spl TA8-4C-13.4 (C14)

Gray fine sand; probably nor in place (sloughed or fill-in). Lower contacl distorted.

Gray silt with abundant scaltered organics (scdge blades, roots).

Gray to brownish gray (minor) laminated silt and clayey silt. Horizonlal laminations $1-5 \mathrm{~mm}$. Tracc scattered organics (sedge blades).

Spl TA8-5B-16.7 at 16.6-16.8 (GS)

Fine sand with some silt and clay (catcher sample; bagged).

Nol recovered.

Disturbed gray clayey silt and silty fine sand. Contorted laminae. No organics.

Gray to brownish gray (at base) laminatcd silt and clayey silt. Minor organics neas base. Lower contact gradational.

Spl TAB-6-20.0 at $19.9 \cdot 20.1$ (GS).

Woody and sedge peat, mixed with silt in upper $0.1 \Omega$.

Spl TA8-6-20.3 at 20.2-20.35 (Ci4).

Sedge peat (catcher sample; bagged).

Probably fill-in (not in place). Gray silt wilh chunks of peat.

Dark brown sedge(?) peat grading downward to organíc-rich silt. Probably the base of pcat layer that starts at 20.2. Sampled to confirm.

Spl 'TA8-7-21.5 at $21.4-21.5$ (C14).

Gray clayey silt and silty finc sand with minor organics ncar top. Faint laminations near base.

Very fine sand with some silt and trace clay (catcher sample; bagged).

Uniform gray silt or fine sandy silt with minor clay. Very faint laminations ncar base. Trace organics.

Spl TA8-8-24.6 at 24.5-24.7(GS).

Dark brown woody/scdge pcat. Sharp upper contact, fairly sharp lower contact. Spl TA8-8-24.8 at 24.75-24.85 (C14)

Uniform gray silt or silty fine sand. Very faint thin laminalions. No organjes.

Very line sand with some silt (calcher samplc; bagged). 
TA8-9

$26.0-28.3$

TA8-9C

TA8-10A

$28.3-28.5$

28.5-30.15

$30.15-30.25$

$30.25-30.6$

TA8-10B

$30.6-30.8$

30.8-33.1

TA8-10C

$33.1-33.2$

$33.2-33.5$

TA8-11A

$33.5-35.65$

TA8-11B

$35.65-35.95$

$35.95-36.2$

$36.2-38.1$

$38.1-38.5$

TA8-12A

TA8-12B

41.0-41.4

41.4-41.55

$41.55-43.5$

TA8-13A

$43.5-46.0$

TA8-13B
Gray to brownish gray silt and silty fine sand with scaltered minor organics (sedge). Disturbed with some contorted laminae in upper $1.0 \mathrm{ft}$. Tap 0.3 it may be fill-in (see log). Contorted layers of sedge blades or roots at 27.7. Distinct thin lamination at 27.2-27.5 and 27.8-28.3.

Very fine sand with some silt (calcher sample; bagged).

Uniform gray silt or silty fine sand with negligible organics. No visible bedding.

Gray to brownish gray thin-bedded to laminated silt and clayey silt. Sharp lower contact with peat.

Spl TA8-10A-30.2 at 30.1-30.25 (GS).

Dark brown sedge and/or sphagnum peat. Compact and horizontally layered. Spl TA8-10A-30.3 at 30.15-30.4 (C14).

Dark brown sedge and/or sphagnum peat. Base of peat layer at $30.25-30.6$ in TA810A. Sharp base.

Gray to brownish gray (minor) silk and silty fine sand. Organic-rich 30.8-31.1. Scallered organics decrease downward. Distinct fine laminations $(0.5-2 \mathrm{~mm})$ at 31.7-33.1. Minor iron staining along colges and near organics.

Very fine sand (catcher sample; bagged).

Not recovered.

Gray clayey silt, nearly uniform. No visible bedding except fine laminations at 33.5-33.7 (top). Rest is massive or disturbed. Minor iron staining along margins. Negligible organics. Faint dark organic smears.

Spl TA8-11A-35.0 at 34.9-35.1 (GS)

Gray to brownish gray silt. No bedding, possibly disturbed. Minor iron staining.

Gray to brownish gray silt interlaycred with organics. Concentrated organic layer $1 / 4$ in. thick at 36.15. Possibly a buried peat layer.

Spl TA8-11R-36.2 at 36.15-36.25 (C14).

Gray to brownish gray silt with interlayered thin organic-rich layers, decreasing downward.

Spl TA8-11B-36.8 at 36.8-36.9 (C14) for sedimentation rate.

Not recovered.

Gray silt. No visible bedding except faint laminalions in lower $1.0 \mathrm{ft}$. trace organics. Truce iron staining.

Gray laminated silt and silty fuse sand. No visible organics.

Gray to brownish gray silt with thin layers of organic material. Possibly a buricd peat layer.

Spl TA8-12B-4I.5 at 41.4-41.55 (C) 4$)$.

Gray to brownish gray silt with scattercd organics and very faint laminations in lower 1.0 nt. No distinct upper contact. Distorted organic zone (sedge?) al 42.3.

Gray clayey silt with trace organics and minor iron staining. Faint lamination at 44.8 to 46.0 .

Spl TAg-13A-45.5 at 45.4 to 45.6 (GS).

Gray silt and/or claycy silt with trace organics and minor iron staining. Faint laminations throughout, most visible at $\$ 7.0$ where iron staining accentualcs coarser laminae. 
TA8-14A

$48.5-50.95$

TA8-14B

$50.95-53.4$

TA8-14C

$53.4-53.7$

Maximum depth sampled $53.7 \mathrm{ft}$.
Gray to brownish gray silt and clayey silt. No visible bedding. Minor iron staining (49.9-50.1). Mottled with dark gray organic smears throughout, especially visible at 50.1 to 50.95 . Probably not a buried peat tayer, but could be useful for defermining sedimentation rate.

Spl TA8-14A-50.5 at 50.4-50.6 (GS). Spl TA8-14A-50.8 at 50.6-50.9 (C14).

Gray to brownish gray silt; laminated to thin bedded, except upper 0.5 ft probably disturbed. Light gray thin partings (volcanic ash?) i to $3 \mathrm{~mm}$ thick at 52.0 and 52.7-58.5.

Silty clay with some Fine sand (catcher sample; bagged).

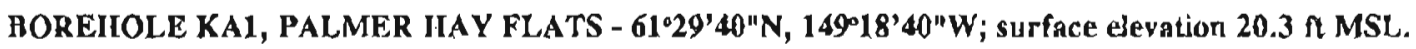

Sample Depth (ft)

$0-0.7$

KAl-l $\quad 0.7-1.0$

$1.0-1.5$

KA $1-2$

$1.5-1.65$

$1.65-2.5$

$\mathrm{KA} 1-2 \mathrm{C}$

$2.5-2.8$

KAIB-1

$2.8-4.3$

$\mathrm{KA}: \mathrm{B}-1 \mathrm{C}$

$4.3-4.5$

KAl-3

$4.0-5.8$

$5.8-6.0$

KAl-3C

$6.0-6.25$

$6.25-7.0$
Description

Not sampled; mostly ice.

Frozen pear and sill; bagged.

Not recovered.

Wet gray silt mixed wilh grass, twigs, and roots, probably disturbed. Appears to be silt layer between surface organics and underlying pcat.

Grayish brown to dark brown peat (wood, sedge, sphagnum?). Larger picces at top. Could have roots from gurface. Some gray silt mixed in top 0.2 in. Spl KA1-2-1.7 al 1.65-1.8 (C14).

Basal peat with small umount of underlying gray silt (catcher sample; bagged).

(From adjacent borehole to sample missed interval at 2.5-4.0 in KAl; 4 fl south of KAl)

Wet gray silt mixed with sedge, Lwigs, and roots. Probabily equivalicnt to 1.5-1.65 in KAl-2.

Brown peat (wood, sedge, sphagnum?). Could be 1964 peat. Equivalent to peat at $1.65-2.5$ in KA!-2. Sampled at base to compare with age of KAI-2-1.7 and avoid possible contamination by roots.

Spl KAIB-1-2.7 at 2.65-2.8 (C:4).

Wet gray clayey silt with faint thin lamination al top (2.8-3.1) and trace organics. Spl KAIB-1-3.1 at 3.0-3.2 (GS).

Gray ckayey silt with minor organics (catcher sample; bagged; from adjacont borehole 4 n south of KA1).

Wet gray clayey silt with very faint laycring and some organics. Also some dark gray organic smcars.

Spl KA1-3-5.7 at 5.6-5.8 (GS).

Dark brown scdge(?) peat grading downward lo brownish gray organic-rich sill. Sharp upper contact. Probably buricd peat lajer.

Spl KA1-3-5.85 at 5.8-5.9 (Cl4).

Gray clayey silt with some organics (calchcr sample; bagged).

Not recovered. 
KA. -4

$7.0-8.5$

KA1-4C

$8.5-8.75$

KA1-5

$8.75-11.3$

KAL-5C

$11.3-11.5$

KAI-6

$11.5-11.7$

11.7 .12 .0

$12.0-13.8$

KAI-6C

$13.8-14.0$

KA1-7

$14.0-16.1$

KAl-7C

$16.1-16.3$

KA1-8

$\mathrm{KA} 1-8 \mathrm{C}$

$18.65-19.0$

KAl-9

KA1-10

KAL $-10 C$

KA1-11

XA1-12

$26.4-28.1$

$28.1-28.15$

$28.15-28.3$

28.3-28.9

KA1-12C

28.9-29.1

$\mathrm{KAl}-13$

29.1-30.7
Gray silt with no visible bedding. Minor organies at 7.7-7.9 (sedge), otherwise rare. Dark gray organic smears throughout.

Gray clayey gifl.

Uniform gray clayey silt with no visible bedding and negligible organics.

Spl KA1-5-10.0 at 9.9-10.1 (GS).

Gray clayey silt (catcher sample; bagged)

Gray clayey silt with no visible bedding. Trace organics. Spl KA1-6-11.6 at 11.5-11.7 (GS).

Dark brown peat (sedge?) grading down to grayish brown organic-rich silt. Upper contact alightly disturted but sharp. Lower contact gcadational. Psabably a buried peat layer.

Spl KA1-6-11.75 at 11.7-11.8 (C14).

Uniform wet gray silt with minor organics near top and trace at boulom. Faint laminations visible at 13.6-13.8.

Gray clayey silt (catcher sample; bagged).

Wet clayey silt with faint layering $(15.0-16.0)$ and no organics.

Gray silt (catcher sample; bagged).

Uniform wet gray clayey silt. Very faint layering 18.0-18.4. Trace organics at 16.7. Several pockets of sedgo blades at 18.1-18.5. Subrounded pebble $3 / 8$ in. diameter at 18.35 , probably ice rafted.

Spl KA1-8-17.9 at 17.8-18.0 (GS).

Spl KA1-8-18.2 at 18.1-18.3 (C14) for sedimentation rate (sedge blades probabiy transported).

Gray silt with some organics (catcher sample; bagged).

Uniform wet gray claycy silt. Fajnt layering (20.9-21.1). Pockets of organics (sedge?) at 19.25-19.5.

Wet gray silt with faint layering (22.5-23.5) and minor scattered organics (e.g.. 22.1, 23.2)

Gray silt (calcher sample; bagged).

Gray clayey sitt with some dark gray organic smcars and moderate layering (sec 25.1-25.6). Very minor organic picces scaltered throughout. Spl KA1-11-25,0 at 24.9-25.1 (GS).

Uniform gray silt with minor dark gray organic smears. Small pockel of organics (sedge) at 27.1 Very faint layering.

Layened gray silt and fine sand. Sand layer $3 \mathrm{~mm}$ thick at 28.15 above organic-rich layer. Too thin to sample for grain size.

Dark gray layered organic-rich silt. Buried peat layer?

Spl $K \wedge 1-12-28.2$ at $28.15-28.3$ (C14).

Gray silt with some dark gray organic smears. Very faint layering.

Gray silt (catcher sample; bagged).

Gray silt with very faint layering. Banded dark gray organic smears at 30.4-30.6. Doubtful buried peat layer, but would give sedimentation ratc.

Spl KAI-13-30.5 at 30.4-30.6 (C14). 
KA I-14

$30.7-33.2$

KA1-14C

33.2-33.5

Maximum depth sampled $33.5 \mathrm{f}$.
Gray sitt with dark banded organic smears at 30.7-31.1, 31.3-31.6, and 32.4-32.5. Orherwise very faint layering. The three dark layers may be buried peats, but doubtíul.

Gray silt (catcher sample; bagged).

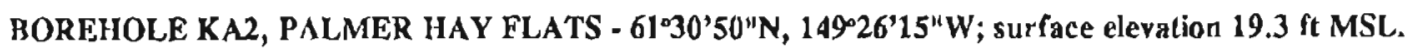

Sample

KA2-1

$\mathrm{KA} 2-2$

3.0-3.85

$3.85-5.35$

$5.35-5.5$

KA2-4

KA2-4C

7.3-7.6

$7.6-8.0$

KA2-5

8.0-9.7

KA2-5C

$9.7-10.0$

10.0-10.5

KA2-6

10.5-12.2

KA2-6C

KA2-7

$13.0-15.0$

KA2-8

$15.0-17.5$

KA2-8C

\section{Description}

Frozen ice-rich peat (bagged).

Not recovered.

Dark brown peat; base of modem surfacc organic layer.

Uniform wet gray silt. No visible bedding. Trace organics (one small pocket of sedge blades at 2.65).

Nol recovered.

Gray sift. No visible bedding or organics. Minor iron staining. Spl KA2-3-3.5 at 3.4-3.6 (GS).

Gray clayey silt with faint laminations, grading downward to interlayerod claycy silt and silly fine sand. Trace organics, minor iron staining.

Spl KA2-3-4.0 at 3.9-4.1 (GS).

Not recovered.

Wet, gray sill, partially liquefied. Very faint bedding, trace organics. Spl KA2-4-7.0 at 6.9-7.1 (GS).

Gray fine sand with abundant mica and little or no silt (catcher sample; bagged). May be nuvial.

Nol recovered.

Gray clayey silt will some laminations of silty fine sand (9.0-9.7). Trace organics, minor iron staining.

Firm gray fine sand (catchcr sample; bagged).

Not recovered.

Gray sill with iron staining along laminations. No visible layering. Possible volcanic-ash parting at 12.1 (very light gray silt-size material).

Gray sill (catcher sample; bagged).

Not recovered.

Gray clayey silt with no visible bedding. Minor iron staining. Trace scaltered organics. Fron staining produces mottling, apparenly associated with organics.

Gray clayey silt. Very faint bedding. Minor iron staining (mottled) at 15.0-16.4. Trace organics.

Gray clayey silt (catcher sample; bagged).

$17.7-18.0$

Not recovered. 
KA2-9

KA2-10

$22.3-23.0$

KA2-11

$23.0-25.3$

$\mathrm{KA} 2-11 \mathrm{C}$

$25.3-25.5$

$\mathrm{KA} 2-12$

25.5-27.5

$\mathrm{K} \wedge 2-13$

28. 0.29 .3

KA2-13C

$29.3-29.6$

$29.6-30.5$

KA2-14

$30.5-31.45$

$\mathrm{KA} 2-14 \mathrm{C}$

$31.45-31.7$

Gray clayey silt. Distinct tamination and thin bodding at $59.5-20.3$. No visible organics. Trace iron staining. Spl KA2-9-20.0 at 19.9-20.1 (GS).

Gray clayey silt with faint layering. Desiccation crack longitudinally along entirc sample. Several fateral cracks. No visible organics; no iron staining.

Dark gray organic-rich claycy silt. Dark organic smears show crudc bcdding. Possible buried peat layer, or useful for age and sedimentation rate. Spl KA2-10-22.4 at 22.3-22.45 (C14).

Gray clayey silk with no visible bedding. Mottlod with small darker gay organic smcars, but organics are negligible.

Pirm gray claycy silt (catcher sample; bagged).

Pirm gray clayey silt with numerous dark gray organic smcars in moltles and layers. Organic-rich zones (buried peal layers?) at 26.0-26.1, 26.7, and distincl layer at 27.05-27.15. Light brown finc-sand interbeds, 1-3 mm thick, possibly volcanic ash (?), at 26.7-26.75, 27.0-27.1, 27.2, and 27.25. Dark organic-rich layers appear oblique to bedding (dipping about $20^{\circ}$ ) at 26.0-26.5.

Spl KA2-12-27.0 at 27.0-27.1 (GS).

Spl KA2-12-27.1 as 27.1-27.2(C14).

Firm gray silt (catcher sample; baggud).

Not recovered.

Firm gray silt wilh thin horizontal scams of dark gray organic-rich silh (29.(1 -9.3).

Firm gray siltt (catchcr sample; bagged).

Nol recovered.

Very firm gray silt or claycy silt with faint lamination; no organics, except minor dark gray mottling.

Very firm gray silt (catcher samplc; bagged).

Maximum depth sampled $31.7 \Omega$.

BOREIIOLF, KA3, PALMER IIAY FLATS - 61030'45"N, 149³0'5"W; surface elevation 19.0 ft MSL.

Sample

Depth (fi)

$0-0.3$

KA3-1

KA3-2

KA3-3

$0.3-0.7$

$0.7-1.0$

$1.0-1.25$

$1.25-2.1$

$2.1-2.8$

KA3-4

\section{Description}

Not recoverod.

Frozen basal surface peat over gray silt (bagged).

Not recovered.

Frozen gray silt; plugged sampler (bagged).

Gray to brownish-gray clayey silt. Probably disturbed at 1.25-1.7. Faint laminations at 1.7-2.1. Brownish color from minor iron staining along margins. No visible organics.

Spl KA3-3-2.0 at 1.9-2.1 (GS).

Not recovercd.

Wet, gray, layered and laminated clayey silt. Coarser layers (slightly darker) may contsin some very line sand. Layers are $2-15 \mathrm{~mm}$ thick with slight dip. Trace organic smears, otherwise no identifiable organics. Minor iron staining 5.0-5.25. Much rust on oulside surface. 
$\mathrm{KA3}-4 \mathrm{C}$

5.25-5.5

KA3-5

5.5-7.8

7.8-8.0

KA3-6

$8.0-8.65$

8.65-9.15

KA3-7

$9.15-9.5$

$9.5-11.6$

11.6-11.8

$11.8-13.0$

KA3-8

$13.0-13.6$

13.6-15.1

KA3-8C

15.1-15.4

15.4-15.5

KA3-9

15.5-17.7

KA3-9C

$17.7-18.0$

KA3-10

19.7-20.1

KA3-11

20.1-22.2

KA3-11C

$22.2-22.5$

Wet gray silh (catcher sample; bagged).

Very wet, gray, layered and laminated claycy sill, like KA3-4. Trace dark gray organic mottles.

Sol KA3-5-7.0 at 6.9-7.1 (GS)

Not recovered.

Wet, gray, layered clayey silt like KA3-4 and 5. No organics.

Massive wet gray claycy silt. No visible layering or organics.

Gray silt with no visible bedding or organics. Continuation of lower unit in KA3-6. Spl KA3-7-9.3 at 9.2-9.4 (GS).

Strongly laminated gray clayey silt and fine sundy sill. Organic-rich laminae at 10.05-10.15. Otherwise no organics.

Spl KA3-7-9.8 at 9.7-9.9 (GS).

Spl KA3-7-10.1 at 10.05-10.15 (C14).

Gray silt (catcher sample; bagged).

Nol recovered.

Disturbed wet gray claycy silt and silly fine sand (probably disturbed in sampling or transport).

Layered wet gray claycy silt and silty fine sand. No visible organics.

Gray silt with one small wood fragment (catcher sample; bagged).

Not recovered.

Wet, gray, silty finc sand. No visible layering except faint laminations at 17.417.7. Core possibly disturbed. No visible arganics.

Gray silly line sand with scaucred small wood fragments (cacher sample; bagged).

Uniform gray very fine sand. Possibly disturbed from liquefaction during sampling or transport. No organics. Channel sand? Spl KA3-10-19,0 at 18.9-19.1 (GS).

Not recovered.

Uniform gray fine sand and (at base) silty fine sand. No visible bedding except faint lamination 22.1-22.2. No visible organics.

Gray fine sand (catcher sample; bagged).

Maximum depth samplod $22.5 \mathrm{ft}$.

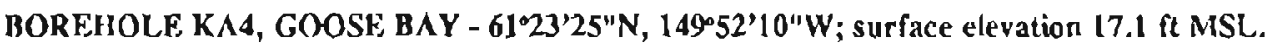

$\underline{\text { Sample }}$

KA4-1 Depth(fit)

$0-0.7$

$0.7-0.8$

KA4-1C

$0.8-1.2$

$1.2-2.9$

\section{Description}

Mixed surface organics (Lwigs, sedge, roots) and wel gray clayey silt.

Dark grayish brown organics (1wigs, rools, sedgc) with minor silt. Relativcly sh:I upper contact and distinctly less silt than above. Could be older peal buried by younger sedimenl and organics anter subinergence.

Spt KA4-1-0.7 at 0.7-0.8 (C14) for age of possible buried peal layer.

Brown peal as above (calcher sample: bagged).

Not recovered. 
KA4-2

2.9-3.0

3.0 .3 .35

$3.35-4.0$

KA4-2C

4.04 .3

4.3-5.5

KA4-3

$5.5-7,6$

KA4-3C

KA4-4

KA4-5

KA4-5C

KA4-6C

KA4-7

$15.5-17.0$

$17.0-17.55$

KA4-7C

KA4-8

KA4-8C

KA4-9

KA4-9C

$22.6-22.9$

$22.9-23.0$
Slough from above - disregard.

Brown woody peat (twigs, sedge, roots, possible sphagnum). Could be base of surface organics. Basal sample collectad for date.

Spl KA4-2-3.3 at 3.25-3.35 (C14).

Sticky gray clayey silt. No visible bedding. Minor dark gray organic mouling. Spl KA4-2-3.4 at 3.35-3.5 (GS).

Gray silt (catcher sample; bagged).

Not recovered.

Firm gray silt with no visible layering and trace organics (sedge). Trace iron staining.

Gray silt with trace organics (catcher sample; bagged).

Same as 5.5-7.6 above but no visible organics.

Brownish gray to gray firm claycy silt with faint lamination (9.2-9.6). Trace organios. More clay-rich at 10.1-11.3.

Spl KA4-5-10.0 at 9.9-10.1 (GS).

Gray clayey silt (catcher sample; bagged).

Not recovered.

Firm gray silt with minor iron staining. Numerous Desiccation cracks. No visible bedding or organics.

Gray silt (catcher sample; bagged).

Not recovered.

Gray to brownish gray silt with faint layering and minor iron staining. Sodge blade and twig at top, otherwise no visible organics.

Gray to dark gray sill with organic smears and mouling. Concentrated dark gray organic zone at 17.3-17.4. Probably not a buried pent layes, but sampled for age and sedimentation rate.

Spl KA4-7.17.3 at 17.25-17.4 (C14).

Gray silt (catcher sample; bagged).

Not recovered.

Dry, firm gray silt with some dark gray organic-rich zones at 19.7-20.1. Breaks into hard chunks.

Gray silt (catcher sample; bagged).

Not recovered.

Dry, very firm, light to dark gray silt with minor organic-rich layers (chareoal?) at 21.6-21.8. Breaks into large chunks.

Spl KA4-9-21.8 at 2!.7-21.85 (C14) for age and sedimentation rate (probably nol a buried peat layer)

Firm gray silt (catcher sample; bagged).

Not recovered. 


\begin{tabular}{|c|c|c|}
\hline KA4-10 & $23.0-25.1$ & $\begin{array}{l}\text { Dry, very lirm, light brownish gray, gray, and some dark gray layered sill. Very } \\
\text { brittle; breaks into chunks. Dark gray organic-rich layer at } 24.15-24.25 \text {, sampled } \\
\text { for age and sedimentation rate (not a buried peat layer). } \\
\text { Spl KA4-10-24,2 at } 24.15-24.25 \text { (C14). }\end{array}$ \\
\hline \multirow[t]{2}{*}{ KA4-10C } & $25.1-25.4$ & Very firm silt (catcher sample; bagged). \\
\hline & $25.4-25.5$ & Not recovered. \\
\hline KA4-11 & $25.5-27.0$ & Dry, very furm and hand gray silt. Very faint layering and no visible organics. \\
\hline KA4-11C & $27.0-27.2$ & Very Erm, dry silt; no organics (catcher sample; bagged). \\
\hline
\end{tabular}

Maximum depth sampled $27.2 \mathrm{ft}$.

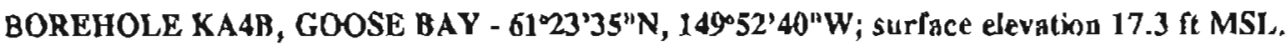

Sample

KA4B-1

Depth (n)

$0-0.8$

KA4B-1C

$0.8-1.0$

KA4B-2C

1.0-1.4

1.4-3.0

KA4B-3C

3.0-3.3

KA4C-1C

$3.0-3.8$

3.8.5.5

KA4B-4

5.5-5.85

KA 4B-4C

7.0-7.3

KA4C-2

5.8-6.35

$7.3-3.0$

KA4B-5

8.0-10.3

KA4C-3

\section{Description}

Bagged; mixed sedge blades, twigs, and water (frozen when corcd) with some roots.

Prozen organic-rich silt; catcher sample; bagged (bagged).

Frozen organic-rich sitt; catcher sample; bagged (bagged); Sampler plugged and pushed through soil withoul recovering core.

Not recovered.

Sedge and woody peat (catcher sample; bagged).

Spl KA4B-3C-3.1 (C14).

(From adjacent borehole to atiempt missed interval at 3.3-5.5 in KA4B)

Peat; bagged.

Not recovered.

Dark brown peat (sedge, twigs, sphagnum?). Probably base of surface organics. Sampled at base for C14 age.

Spl KA48-4-5.8 at 5.75-5.85 (C14).

Wet gray clayey sitt with no visible bedding and minor organics. Spl KA4B-4-6.0 at 5.9-6.05 (GS).

Gray aticky clayey silt with organics (catcher sample; bagged).

(From adjacent borehole to attempt missed interval in KAdB; unsuccessful)

Same as \$.5-5.85 in KA4B-4.

Same as $5.85-7.0$ in $\mathrm{KA} 4 \mathrm{~B}-4$.

Not recovered.

Gray clayey silt with faint layering. Trace organics at 8.25 and 9.35 .

(From adjacent borehole 2 it away; same interval as KA4B-5; unsuccessful attempt to resample 7.25-8.0)

$8.0-8.5$

Soft, wet organics. Probably fill-in from higher in hole (not in place). 
8.5-10.15

$10.3-10.5$

KA4B-6

$10.5-12.85$

KA4B-6C

$12.85-13.2$

13.2-13.3

KA4B-7

$13.3-14.25$

KA4B-7C

$14.25-14.4$

$14.4-15.5$

KA4B-8

KA4B-8C

$17.1-17.3$

$17.3-18.0$

KA4B-9

$18.0-20.5$

KA4B-10

$20.5-22.9$

$\mathrm{KA} 4 \mathrm{~B}-11$

$22.9-25.4$
Wel, gray sith with minor scyttered organics and some dark gray organic motling. Twigs (1/2 in. dia.) at 9.4 and 9.9 , possibly transported (asthough bark still intacl).

Not recovered.

Moist gray clayey silt with faint laycring and laminations. Void of unknown origin (nol distunted) at 10,85. Trace scaltered organics. More concentrated organics (sedge?) at 12.6-12.8. Sampled for age and sedimentation rate (not a buried peat layer).

Spl KA4B-6-12.7 at 12.6-12.75 (C14).

Gray sticky silt with minor organics (calcher sample; bagged).

Not recovered.

Uniform gray clayey wilt. No visible bedding; trace organic smears.

Stiff gray silt (catcher sample; bagged).

Not recovered.

Uniform gray clayey silt. Minor crudely layered but distorted dark gray organicrich layers at $36.9-17,0$.

Gray silt (catcher samplc; bagged).

Nat racovered.

Gray to dark gray claycy silt. Several arcas of dark gray organic-rich mollling and layering $(18.2-18.3,18.9-19.0,19.2-19.3,19.4)$.

Very firm, nearly dry, gray so light brownish gray claycy silt. Distinct but disturbod laycring. Light brownish gray zones along cracks and partings, possibly from iron staining. No visible organics, but darker gray zones may be slightly organic-rich. Concoidally fractured.

Same as KA4B-10. Scveral small (up to $1 / 4 \mathrm{in}$ ) subrounded pebbles at 24.8 . No visible organics.

Spl KA4B-11-24.3 at 24.7-24.9 (GS).

Maximum depth sampled $25.4 \mathrm{f}$.

BOREHOLE KA5, PALMER IIAY FLATS - 61³1'40"N, 149.26'55"W; surface elevation $21.4 \mathrm{ft}$ MSI.

Sample

Depth (ft)

0.4 .7

KAS-1

4.7-5.1

$5.1-6.0$

$6.0-6.25$

KA5-1C

$6.25-6.5$

KA5-2

6.5-8.2

\section{Description}

Not sampled; organics and water.

Brown to dark brown woody, sedge, and sphagnum(?) peat. Sharp base. Sol KA5-1-5.0 at 5.0-5.1 (C14).

Wel, gray, layered silt with trace organies. Spl KA5-1-5,6 at 5.5-5.7 (GS).

Wet, gray, claycy silt with faint layering and no visible organics. Spl KA5-1-6.2 at 6.1-6.25 (GS).

Gray sill with minor organics (catcher sample; bagged).

Wet, gray, laminated silt and claycy silt. Laminge dip $10-30^{\circ}$ at $6.5-7.3$. No visible organics. 
KAS-2C

8.2-8.6

KA5-3

$8.6-8.95$

KA5-4

9.0-9.7

$9.7-11.4$

KA5-4C

$11.4-11.8$

XA5-5

$11.8-13.2$

KA5-6

$13.2-15.7$

XA5.6C

$15.7-16.0$

KA5-7

$16.0-16.5$

KA5-8

$16.5-18.7$

18.7-18.9

KA5-8C

$18.9-19.0$

KA5-9

$19.0-19.95$

KA5-10

$19.95-22.45$

KA5-10C

22.45-22.7

$22.7-24.0$

KAS-11

$24.0-25.95$

KA5-11C

$25.95-26.2$

$26.2-26.5$

KA5-12

26.5-27.0

$27.0-29.0$

KAS-13

$29.0-30.85$

KA5-13C

30.85-31.1
Gray silt (calcher sample; bagged).

Wet, gray, laminated sill and clayey silt. No visible organics.

Wer, gray silt and clayey sílt with distorted laminae.

Wet, gray, laminated and thin-layered silt and clayey silt. Dark gray silk laycr at 10.25-10.35 may be slightly organic-rich. Dark gray organic-rich(?) moleling at 10.6-11.0.

Spl KAS-4-10.0 at 9.9-10.1 (GS).

Gray silt (calcher sample; bagged).

Wet, gray, laminated and thin-layered silk and claycy silt. Disturbed at 11.8-12.7. No visible organics.

Moist, gray, Laminated and thin-layered silt and claycy silt. No visible organics.

Cross-bedded fine-sandy layers at 14.5-14.7.

Sol KA5-6-15.3 at 15.2-15.4 (GS), silt.

Spl KA5-6-15.6 at 15.55-15.7 (GS), clayey silt.

Gray silt (catcher sample; bagged).

Gray silt (bagged).

Moist, gray, layered silt and clayey silt. Layering less distinct than in KA5-6. No visible organics.

Uniform gray clay or clayey silt. No visible layering or organics.

Gray sill (catcher sample; bagged).

Uniform gray clay or clayey sill. No visible layering or organics. Conlinuation of layer staring at 18.7 .

Firm, uniform gray silty clay, No visible bodding, except faint dark thin ( $<1 / 8$ in.) gray organic-rich(?) laycr at 21.6 .

Spl KA5-10-21.0 at 20.9-21.1 (GS).

Gray silt (catcher sample; bagged).

Not recovered.

Same as KA5-10. Slighlly organic-rich (dark gray) layer at 25.4-25.5. Small piece of twig at 25.4 .

Gray silty clay (catcher samplc; bagged).

Not recovered.

Same as KA5-10 and KA5-11.

Not recovered. Sample slid out of tube during recovery.

Gray silly clay, same as KA5-10, 11 , and 12 . Very faint darker gray zones, possibly organic-rich (for example, 30.1-30.15).

Spl KAS-13-30.0 at 29.9-30.1 (GS).

No change (calcher sample; bagged).

Maximum depth sampled $31.1 \mathrm{ft}$. 


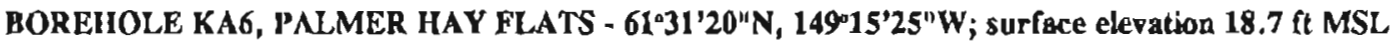

Sample

Depth (fit)

0.0 .5

$0.5-1.9$

KAG-1

KAG-2

$1.9-2.2$

$2.2 \cdot 2.35$

2.35-2.95

2.95-3.2

3.2.3.4

KAG-2C

3.43.7

3.7 .4 .0

KA6-3

4.0-4.3

$4.3-4.375$

$4.375-4.45$

$4.45-4.55$

4.55-5.15

KA6-3C

5.15-5.4

5.4-6.5

KA6-4

6.5-7.3

7.3-7.4

7.4-7.525

7.525-7.575

$7.575-7.8$

7.8-7.9

KAG-4C

7.9-8.1

8.1-9.0

KA6-5

Ice.

Prozen silt and organics (not recovered).

Base of frozen silt (bagged).

Sedge and woody peat mixed with some gray silt. Could be basal surface peat, base of older peat, or fill-in from borchole wall above.

Spl KA6-2-2.3 at 2.2-2.35 (C14).

Uniform gray silty clay with scaucred organics. Slightly organic-rich layer at 2.62.7. Sharp base.

Spl K^6-2-2.9 at 2.8-2.95 (GS).

Brown to dark brown sedge and sphagnum(?) peat. Sharp upper and lower contacts.

Spl K\6-2-3.0 at 2.95-3.05 (C14).

Uniform gray claycy silt. No organics.

Gray claycy silt (catcher sample; hagged).

Not recovered.

Gray clayey silt with scattered organics and very laint layering.

Very dark brown compressed scdge or sphagnum peat. Sharp top and boltom. Spl KA6-3-4.35 al 4.3-4.375 (C14).

Light brownish gray organic-rich silt or ash(?).

Spl Kᄉ6-3-4.4 for microscopy.

Dark brown compressed sedge or splagnum peat. Could be slighlly older submerged layer (2 events?). Sharp base, gradational top.

Gray elayey silt wilh very faint layering and scattered organics.

Gray silt (catcher sample; bagged).

Nol recovered.

Uniform gray clayey silt with no visible bedding or organics.

Laminated gray clayey silt and silly fine sand. Minor dark gray organic(?) smcar.

Gray claycy silt with no visible bedding. Minor gray organic(?) smcar.

Grayish brown organic-rich silt.

Spl KA6-4-7.55 at 7.525-7.575 (C14).

Gray clayey silt with scallered organics. No visible bedding.

Dark brown compressed peat. Sharp top and boltom.

Spl KA6-4.7.85 at 7.8-7.9 (C14).

Gray silt (catcher sample; bagged).

Not rocovered.

Very wet, disturbed clayey silt with faint layering and minor dark gray organic smears. 
KA6-6

KA6-7

11.5-13.85

$13.85-14.0$

KA6-8

KA6-9

KAG-10

KAG-11

KA6-12

$19.0-20.95$

$20.95-21.5$

KA6-13

$2\{.5-23.15$

KA6-13C

23.15-23.4

$23.4-24.0$

KA6-14

KA6-14C

$25.65-25.9$

KA6-15

26.5-28.75

KAG-15C

$28.75-29.0$

KA6-16

$29.0-31.5$

KA6-17

31.5-33.75

KA6-17C

$33.75-34.0$

KA6-18

$34.0-36.5$

KAG-19

$36.5-38.2$
Same as KA6-5.

Not recovered.

Wet gray clayey silt with faint disturbed bedding and scattered organics. Pocket of sedge(?) at 13.1. Mouled with dark gray smears, possibly fine organics.

Spl KAG-7-12,0 at 11.0-12.1 (GS).

Not recovered.

Extra materisl from unknown source (structure precludes fill-in from borehole walls). Rocovered at same apparent interval as KA6-7. Wet gray clayey silt with scattered organics. Some distinct layering in lower half. Upper part disturbed.

Wet, uniform gray clayey silt with trace scattered organics and slight iron staining at $16.2-16.45$.

Gray clayey silt with some organics.

Gray clayey silt with laint layering and some iron staining at 16.5-18.4. Dislinct layering and lamination at 18.4-18.95, and no iron staining. Trace scattered organics.

Gray silty clay with very faint layering and no visible organics. Sevcral thin (1/ 8 in.) fine-sandy partings at 20.2-20.3.

Spl KA6-12-20.0 at 19.9-20.1 (GS).

Not recovered.

Firm, gray clayey silt with very faint layering and no visible organics.

Gray clayey silt (catcher sample; bagged).

Nol recovered.

Firm, gray claycy sil. Very faint layering and no visible organics at 24.0-25.2. Distinct layering uccenluated by dark gray organic smears at 25.2-25.65. Darkcst layer at 25.25-25.3.

Spl KA6-14-25.3 at 25.25-25.35 (Cl4).

Gray clayey silt (calcher sample; bagged).

Not recovered.

Firm, gray to dark gray clayey silt with no visible bedding. Numerous dark gray organic smears.

Firm gray clayey silt with $1 / 2$ in. dark gray organic-rich laycr.

Firm, gray clayey silt with minor dark gray organic smears. No visible bedding. Spl KA6-16-30.0 at 29.9-30.1 (GS).

Same as above. Thin (1/4 in.) dark gray organic-rich(?) layer at 32.75 . Trace fine sandy lenses at (e.g. $31.7,32.65)$.

Gray clayey silt with faint dark gray organic smears near top (catcher sample; bagged).

Pirm gray claycy silt with minor dark gray organic smears. Numerous light gray fine sandy lenses and partings at 35.9-36.5.

Firm, gray clayey silt with trace dark gray organic smears, distored fajnt laycring, and several light gray fine-sandy lenses. 
$38.2 \cdot 38.55$

$38.55-39.0$

KA6-20

$39.0-39.6$

$39.6-40.2$

$40.2-40.45$

$40.45-41.25$

KA6-21

$41.25-41.9$

$41.9-42.35$

$42.35-43.35$

$43.55-43.75$

$\mathrm{KAG-21C}$

$43.75-44.0$
Interiayered grayish brown silty fine sand and brownish gray to gray fine-sandy sill and clayey silt. Slightly distorted layering. No visible organics.

Spl KA6-19-38.4 at 38.35-38.45 (GS).

Uniform gray silty clay with no visible bedding or organics. Trace fine sand. Spl KAG-19-38.8 at 38.7-38.9 (GS).

Gray silty clay with faint distorted layering; probably disturbcd. No organics.

Gray laminated clayey sile and silty fine sand. Laminac tilted and distorted al 39.639.9. No visible organics.

Gray to grayish brown silky fine sand. No visible bedding or organics.

Soft gray silt and claycy silt with distorted bedding. No visible organics.

Soft gray clayey silt with interbeds of silty fino sand. Distortco bcoding at 41.25 41.6. Less disturbed at 41.6-41.9. Layering is horimonta] at base. Possibly trace organics at 41.85 .

Grayish brown fine sand with distorted interbeds of gray claycy silt. No visible bodding.

Distorted interbeds of gray clayey sill and silly fine sand. No visible organics.

Horizontul interbeds of gray fine sand and claycy silt. No visible organics.

Firm gray silty fine sand (calcher sample; bagged).

Maximum depth sampled $44.0 \mathrm{f}$.

RIVER BLUFF SECTION KA7, PALMER IAY FLATS - loc. near KA1; surface elev, about $18 \mathrm{ft}$ MSI.

Sample

Depth (ft)

0.3 .0

KA7-3.0

KA7-3.5
30

3.5

\section{Description}

Not sampled; grayish brown silt with plant fragments and roots near surface.

Flatlened wood picces and twigs lying horizontally in a discominuous layer up to 1 in. $(2.5 \mathrm{~cm})$ thick.

Spl KA7-3.0 at 3.0 fr (C14).

Sedge and woody peat in a laterally extensive but discontinuous layer up to 1 in. $(2.5 \mathrm{~cm})$ thick.

Spl KA7-3.5 at $3.5 \mathrm{At}(\mathrm{Cl} 4)$. 


\section{APPENDIX B}

Tablo 8-1. Grain-size anahyses. Mean dianeter and standard deviation are plotled in figures B-1 through B-9.)

\begin{tabular}{|c|c|c|c|c|c|c|c|c|c|c|}
\hline $\begin{array}{l}\text { Bore- } \\
\text { hole }\end{array}$ & Sample deplh & $\begin{array}{l}\text { Mcan di- } \\
\text { am(mm)' }\end{array}$ & $\begin{array}{l}\text { Mean di- } \\
\operatorname{am}(\phi)^{*}\end{array}$ & $\begin{array}{c}\text { Standard } \\
\text { deviation* }\end{array}$ & $\begin{array}{l}\text { Skew- } \\
\text { ness* }\end{array}$ & $\begin{array}{l}\text { Kur- } \\
\text { tosis* }\end{array}$ & $\begin{array}{l}\text { Percent } \\
\text { gravel }\end{array}$ & $\begin{array}{c}\text { Percent } \\
\text { sand }\end{array}$ & $\begin{array}{l}\text { Percent } \\
\text { silt }\end{array}$ & $\begin{array}{c}\text { Percent } \\
\text { clay }\end{array}$ \\
\hline $\begin{array}{l}\text { TA1 } \\
\text { TA1 } \\
\text { TA1 } \\
\text { TA1 } \\
\text { TA1 } \\
\text { TA1 } \\
\text { TA1 } \\
\text { TA1 } \\
\text { TA1 } \\
\text { TA1 }\end{array}$ & $\begin{array}{l}17.1 \mathrm{ft}(5.21 \mathrm{~m}) \\
19.0 \mathrm{ft}(5.79 \mathrm{~m}) \\
25.3 \mathrm{ft}(7.71 \mathrm{~m}) \\
26.3 \mathrm{ft}(8.02 \mathrm{~m}) \\
33.0 \mathrm{ft}(10.06 \mathrm{~m}) \\
36.5 \mathrm{ft}(11.13 \mathrm{~m}) \\
41.8 \mathrm{ft}(12.74 \mathrm{~m}) \\
45.6 \mathrm{ft}(13.90 \mathrm{~m}) \\
57.0 \mathrm{ft}(17.38 \mathrm{~m}) \\
61.0 \mathrm{ft}(18.60 \mathrm{~m})\end{array}$ & $\begin{array}{l}0.0122 \\
1.5801 \\
0.0043 \\
0.0047 \\
0.0060 \\
0.0126 \\
0.0166 \\
0.0209 \\
0.0337 \\
0.0270\end{array}$ & $\begin{array}{r}6.36 \\
-0.66 \\
7.85 \\
7.74 \\
7.38 \\
6.31 \\
5.91 \\
5.58 \\
4.89 \\
5.21\end{array}$ & $\begin{array}{l}1.74 \\
1.56 \\
1.79 \\
1.87 \\
2.11 \\
2.14 \\
1.94 \\
1.68 \\
1.27 \\
1.30\end{array}$ & $\begin{array}{l}1.51 \\
0.79 \\
0.41 \\
0.28 \\
0.51 \\
1.09 \\
1.23 \\
1.66 \\
2.45 \\
2.42\end{array}$ & $\begin{array}{l}4.43 \\
3.56 \\
2.31 \\
2.43 \\
2.13 \\
3.08 \\
3.29 \\
4.89 \\
8.77 \\
9.07\end{array}$ & $\begin{array}{r}0.00 \\
61.71 \\
0.00 \\
0.00 \\
0.00 \\
0.00 \\
0.00 \\
0.00 \\
0.00 \\
0.00\end{array}$ & $\begin{array}{r}0.00 \\
36.71 \\
0.00 \\
0.90 \\
0.40 \\
5.00 \\
4.00 \\
4.70 \\
11.80 \\
4.20\end{array}$ & $\begin{array}{r}83.73 \\
1.58 \\
58.21 \\
58.50 \\
64.00 \\
74.00 \\
78.70 \\
83.70 \\
82.40 \\
89.60\end{array}$ & $\begin{array}{r}16.27 \\
0.00 \\
41.79 \\
40.60 \\
35.60 \\
21.00 \\
17.30 \\
11.60 \\
5.80 \\
6.20\end{array}$ \\
\hline $\begin{array}{l}\text { TA8 } \\
\text { TA8 } \\
\text { TA8 } \\
\text { TA8 } \\
\text { TA8 } \\
\text { TA8 } \\
\text { TA8 } \\
\text { TA8 } \\
\text { TA8 } \\
\text { TA8 }\end{array}$ & $\begin{array}{l}4.7 \mathrm{ft}(1.43 \mathrm{~m}) \\
9.5 \mathrm{f}(2.90 \mathrm{~m}) \\
12.5 \mathrm{ft}(3.81 \mathrm{~m}) \\
16.7 \mathrm{ft}(5.09 \mathrm{~m}) \\
20.0 \mathrm{ft}(6.10 \mathrm{~m}) \\
2.4 .6 \mathrm{ft}(7.50 \mathrm{~m}) \\
30.2 \mathrm{ft}(9.21 \mathrm{~m}) \\
35.0 \mathrm{ft}(10.67 \mathrm{~m}) \\
45.5 \mathrm{ft}(13.87 \mathrm{~m}) \\
50.5 \mathrm{ft}(15.40 \mathrm{~m})\end{array}$ & $\begin{array}{l}0.1321 \\
0.1058 \\
0.0145 \\
0.0126 \\
0.0154 \\
0.0212 \\
0.0182 \\
0.0137 \\
0.0050 \\
0.0047\end{array}$ & $\begin{array}{l}2.92 \\
3.24 \\
6.11 \\
6.31 \\
6.02 \\
5.56 \\
5.78 \\
6.19 \\
7.64 \\
7.73\end{array}$ & $\begin{array}{l}0.79 \\
0.57 \\
1.65 \\
1.45 \\
1.45 \\
1.18 \\
1.32 \\
1.72 \\
1.92 \\
1.62\end{array}$ & $\begin{array}{l}0.16 \\
0.38 \\
1.19 \\
1.38 \\
1.67 \\
2.04 \\
1.50 \\
1.32 \\
0.43 \\
0.43\end{array}$ & $\begin{array}{l}2.33 \\
2.47 \\
3.59 \\
4.18 \\
5.17 \\
6.92 \\
4.60 \\
3.65 \\
2.20 \\
2.59\end{array}$ & $\begin{array}{l}0.00 \\
0.00 \\
0.00 \\
0.00 \\
0.00 \\
0.00 \\
0.00 \\
0.00 \\
0.00 \\
0.00\end{array}$ & $\begin{array}{r}8.5 .94 \\
85.43 \\
2.00 \\
0.00 \\
0.00 \\
1.10 \\
1.20 \\
0.20 \\
0.20 \\
0.00\end{array}$ & $\begin{array}{l}14.06 \\
14.57 \\
83.10 \\
85.94 \\
88.81 \\
91.80 \\
89.00 \\
83.50 \\
61.30 \\
61.53 .\end{array}$ & $\begin{array}{r}0.00 \\
0.00 \\
14.90 \\
14.06 \\
11.19 \\
7.10 \\
9.80 \\
16.30 \\
38.50 \\
38.47\end{array}$ \\
\hline $\begin{array}{l}\text { KA1 } \\
\text { KA1 } \\
\text { KA1 } \\
\text { KA1 } \\
\text { KA1 } \\
\text { KA1 }\end{array}$ & $\begin{array}{l}3.1 \cap(0.95 \mathrm{~m}) \\
5.7 \mathrm{~A}(1.74 \mathrm{~m}) \\
10.0 \mathrm{~A}(3.05 \mathrm{~m}) \\
11.6 \mathrm{~A}(3.54 \mathrm{~m}) \\
17.9 \mathrm{~A}(5.46 \mathrm{~m}) \\
25.0 \mathrm{~A}(7.62 \mathrm{~m})\end{array}$ & $\begin{array}{l}0.0043 \\
0.0044 \\
0.0056 \\
0.0052 \\
0.0067 \\
0.0039\end{array}$ & $\begin{array}{l}7.87 \\
7.82 \\
7.48 \\
7.59 \\
7.23 \\
7.99\end{array}$ & $\begin{array}{l}2.03 \\
2.03 \\
1.70 \\
2.07 \\
1.86 \\
2.05\end{array}$ & $\begin{array}{l}0.34 \\
0.56 \\
0.35 \\
0.64 \\
0.83 \\
0.39\end{array}$ & $\begin{array}{l}2.04 \\
2.44 \\
2.03 \\
2.47 \\
2.74 \\
2.22\end{array}$ & $\begin{array}{l}0.00 \\
0.00 \\
0.00 \\
0.00 \\
0.00 \\
0.00\end{array}$ & $\begin{array}{l}0.00 \\
0.10 \\
0.00 \\
0.00 \\
0.00 \\
0.20\end{array}$ & $\begin{array}{l}56.33 \\
59.30 \\
63.96 \\
63.60 \\
71.20 \\
54.90\end{array}$ & $\begin{array}{l}43.67 \\
40.60 \\
36.04 \\
36.40 \\
28.80 \\
44.90\end{array}$ \\
\hline $\begin{array}{l}\mathrm{KA2} \\
\mathrm{KA2} \\
\mathrm{KA2} \\
\mathrm{KA2} \\
\mathrm{KA2}\end{array}$ & $\begin{array}{l}3.5 \mathrm{n}(1.07 \mathrm{~m}) \\
4.0 \mathrm{ft}(1.22 \mathrm{~m}) \\
7.0 \mathrm{ft}(2.13 \mathrm{~m}) \\
20.0 \mathrm{ft}(6.10 \mathrm{~m}) \\
27.0 \mathrm{ft}(8.23 \mathrm{~m})\end{array}$ & $\begin{array}{l}0.0140 \\
0.0042 \\
0.0148 \\
0.0034 \\
0.0040\end{array}$ & $\begin{array}{l}6.16 \\
7.91 \\
6.08 \\
8.18 \\
7.95\end{array}$ & $\begin{array}{l}1.50 \\
1.97 \\
1.61 \\
1.96 \\
2.26\end{array}$ & $\begin{array}{l}1.43 \\
0.24 \\
1.54 \\
0.33 \\
0.40\end{array}$ & $\begin{array}{l}4.47 \\
2.10 \\
4.51 \\
2.26 \\
2.11\end{array}$ & $\begin{array}{l}0.00 \\
0.00 \\
0.00 \\
0.00 \\
0.00\end{array}$ & $\begin{array}{l}0.80 \\
0.90 \\
0.40 \\
0.00 \\
0.30\end{array}$ & $\begin{array}{l}86.30 \\
53.70 \\
86.00 \\
50.60 \\
55.20\end{array}$ & $\begin{array}{l}12.90 \\
45.40 \\
13.60 \\
49.40 \\
44.50\end{array}$ \\
\hline $\begin{array}{l}\mathrm{KA3} \\
\mathrm{KA3} \\
\mathrm{KA3} \\
\mathrm{KA3} \\
\mathrm{KA3}\end{array}$ & $\begin{array}{l}2.0 \mathrm{ft}(0.61 \mathrm{~m}) \\
7.0 \mathrm{ft}(2.13 \mathrm{~m}) \\
9.3 \mathrm{ft}(2.84 \mathrm{~m}) \\
9.8 \mathrm{ft}(2.99 \mathrm{~m}) \\
19.0 \mathrm{ft}(5.79 \mathrm{~m})\end{array}$ & $\begin{array}{l}0.0091 \\
0.0067 \\
0.0045 \\
0.0158 \\
0.0652\end{array}$ & $\begin{array}{l}6.78 \\
7.23 \\
7.80 \\
5.98 \\
3.94\end{array}$ & $\begin{array}{l}1.83 \\
2.21 \\
1.94 \\
1.57 \\
0.88\end{array}$ & $\begin{array}{l}1.19 \\
1.02 \\
0.42 \\
2.12 \\
1.62\end{array}$ & $\begin{array}{l}3.37 \\
2.92 \\
2.06 \\
6.96 \\
0.69\end{array}$ & $\begin{array}{l}0.00 \\
0.00 \\
0.00 \\
0.00 \\
0.00\end{array}$ & $\begin{array}{r}0.00 \\
0.00 \\
0.00 \\
0.00 \\
56.40\end{array}$ & $\begin{array}{l}78.00 \\
71.10 \\
58.29 \\
89.41 \\
42.90\end{array}$ & $\begin{array}{r}22.00 \\
28.90 \\
41.71 \\
10.59 \\
0.70\end{array}$ \\
\hline $\begin{array}{l}\text { KA4 } \\
\text { KA4 }\end{array}$ & $\begin{array}{l}3.4 \Omega(1.04 \mathrm{~m}) \\
10.0 \mathrm{n}(3.05 \mathrm{~m})\end{array}$ & $\begin{array}{l}0.0039 \\
0.0057\end{array}$ & $\begin{array}{l}7.99 \\
7.46\end{array}$ & $\begin{array}{l}1.83 \\
1.73\end{array}$ & $\begin{array}{l}0.24 \\
0.54\end{array}$ & $\begin{array}{l}2.20 \\
2.57\end{array}$ & $\begin{array}{l}0.00 \\
0.00\end{array}$ & $\begin{array}{l}0.00 \\
0.20\end{array}$ & $\begin{array}{l}53.20 \\
66.20\end{array}$ & $\begin{array}{l}46.80 \\
33.60\end{array}$ \\
\hline $\begin{array}{l}\text { KA4B } \\
\text { KA4B }\end{array}$ & $\begin{array}{c}6.0 \mathrm{ft}(1.83 \mathrm{~m}) \\
24.8 \mathrm{R}(7.56 \mathrm{~m})\end{array}$ & $\begin{array}{l}0.0036 \\
0.0044\end{array}$ & $\begin{array}{l}8.12 \\
7.83\end{array}$ & $\begin{array}{l}2.06 \\
2.13\end{array}$ & $\begin{array}{l}0.48 \\
0.48\end{array}$ & $\begin{array}{l}2.27 \\
2.25\end{array}$ & $\begin{array}{l}0.00 \\
0.00\end{array}$ & $\begin{array}{l}0.00 \\
0.00\end{array}$ & $\begin{array}{l}54.00 \\
58.00\end{array}$ & $\begin{array}{l}46.00 \\
42.00\end{array}$ \\
\hline $\begin{array}{l}\text { KA5 } \\
\text { KA5 } \\
\text { KAS } \\
\text { KAS } \\
\text { KA5 } \\
\text { KA5 } \\
\text { KA5 }\end{array}$ & $\begin{array}{l}5.6 \mathrm{f}(1.71 \mathrm{~m}) \\
6.2 \mathrm{~A}(1.89 \mathrm{~m}) \\
10.0 \mathrm{~A}(3.05 \mathrm{~m}) \\
15.3 \mathrm{ft}(4.66 \mathrm{~m}) \\
15.6 \mathrm{ft}(4.76 \mathrm{~m}) \\
21.0 \mathrm{ft}(6.40 \mathrm{~m}) \\
30.0 \mathrm{ft}(9.15 \mathrm{~m})\end{array}$ & $\begin{array}{l}0.0119 \\
0.0056 \\
0.0075 \\
0.0157 \\
0.0036 \\
0.0029 \\
0.0023\end{array}$ & $\begin{array}{l}6.39 \\
7.49 \\
7.06 \\
5.99 \\
8.13 \\
8.45 \\
8.78\end{array}$ & $\begin{array}{l}1.68 \\
1.70 \\
1.71 \\
1.71 \\
2.01 \\
1.79 \\
1.88\end{array}$ & $\begin{array}{l}1.15 \\
0.45 \\
0.96 \\
1.96 \\
0.25 \\
0.21 \\
0.02\end{array}$ & $\begin{array}{l}3.37 \\
2.53 \\
3.02 \\
6.12 \\
2.26 \\
2.52 \\
2.45\end{array}$ & $\begin{array}{l}0.00 \\
0.00 \\
0.00 \\
0.00 \\
0.00 \\
0.00 \\
0.00\end{array}$ & $\begin{array}{l}1.00 \\
0.00 \\
0.00 \\
0.00 \\
0.10 \\
0.10 \\
0.20\end{array}$ & $\begin{array}{l}81.80 \\
64.70 \\
74.48 \\
88.02 \\
50.30 \\
42.70 \\
35.40\end{array}$ & $\begin{array}{l}17.20 \\
35.30 \\
25.52 \\
11.98 \\
49.60 \\
57.20 \\
64.40\end{array}$ \\
\hline $\begin{array}{l}\text { KA6 } \\
\text { KA6 } \\
\text { KA6 } \\
\text { KA6 } \\
\text { KA6 } \\
\text { KA6 }\end{array}$ & $\begin{array}{c}2.9 \mathrm{ft}(0.88 \mathrm{~m}) \\
12.0 \mathrm{f}(3.66 \mathrm{~m}) \\
20.0 \mathrm{f}(6.10 \mathrm{~m}) \\
30.0 \mathrm{~A}(9.1 .5 \mathrm{~m}) \\
38.4 \mathrm{ft}(11.71 \mathrm{~m}) \\
38.8 \mathrm{ft}(11.83 \mathrm{~m})\end{array}$ & $\begin{array}{l}0.0026 \\
0.0076 \\
0.0022 \\
0.0045 \\
0.0203 \\
0.0023\end{array}$ & $\begin{array}{l}8.59 \\
7.04 \\
8.80 \\
7.79 \\
5.62 \\
8.79\end{array}$ & $\begin{array}{l}1.77 \\
1.94 \\
1.88 \\
1.87 \\
1.94 \\
2.12\end{array}$ & $\begin{array}{r}-0.19 \\
0.93 \\
0.21 \\
0.31 \\
1.59 \\
-0.25\end{array}$ & $\begin{array}{l}2.51 \\
2.89 \\
2.26 \\
2.23 \\
4.51 \\
2.20\end{array}$ & $\begin{array}{l}0.00 \\
0.00 \\
0.00 \\
0.00 \\
0.00 \\
0.00\end{array}$ & $\begin{array}{l}0.60 \\
0.50 \\
0.00 \\
0.00 \\
6.40 \\
0.00\end{array}$ & $\begin{array}{l}36.50 \\
74.10 \\
37.91 \\
57.80 \\
79.40 \\
3.00\end{array}$ & $\begin{array}{l}62.90 \\
25.40 \\
62.09 \\
42.20 \\
14.20 \\
66.00\end{array}$ \\
\hline
\end{tabular}

- Mean diam $(\phi)=-\log _{2}$ (mean diam ${ }_{0 \infty}$ ). Standard deviation, skewness, and kurtosis arc in phi units. 

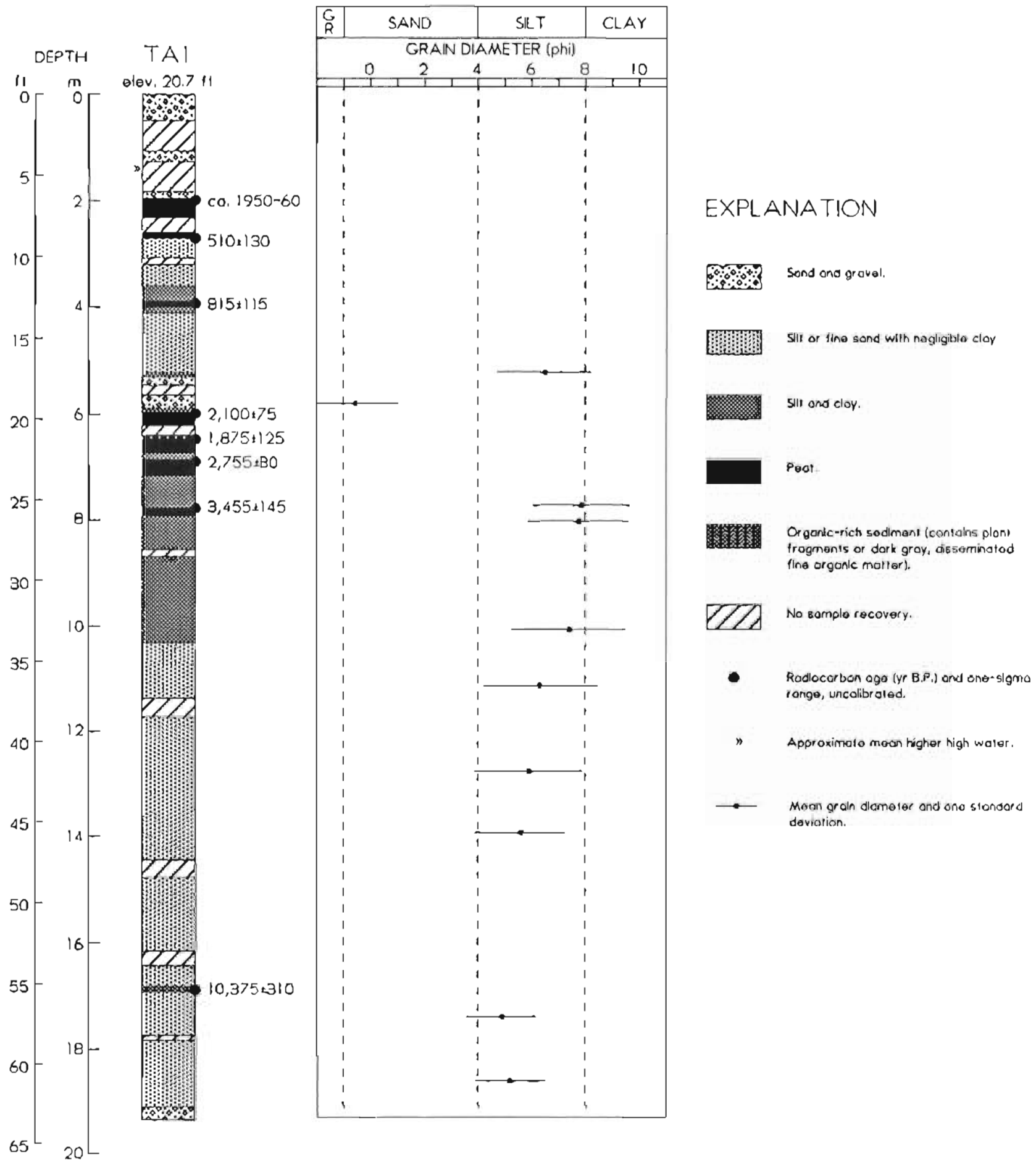

Figure B-1. Lishologic log and plot of grain-size analyses for borehole TAl (Girdwood). 


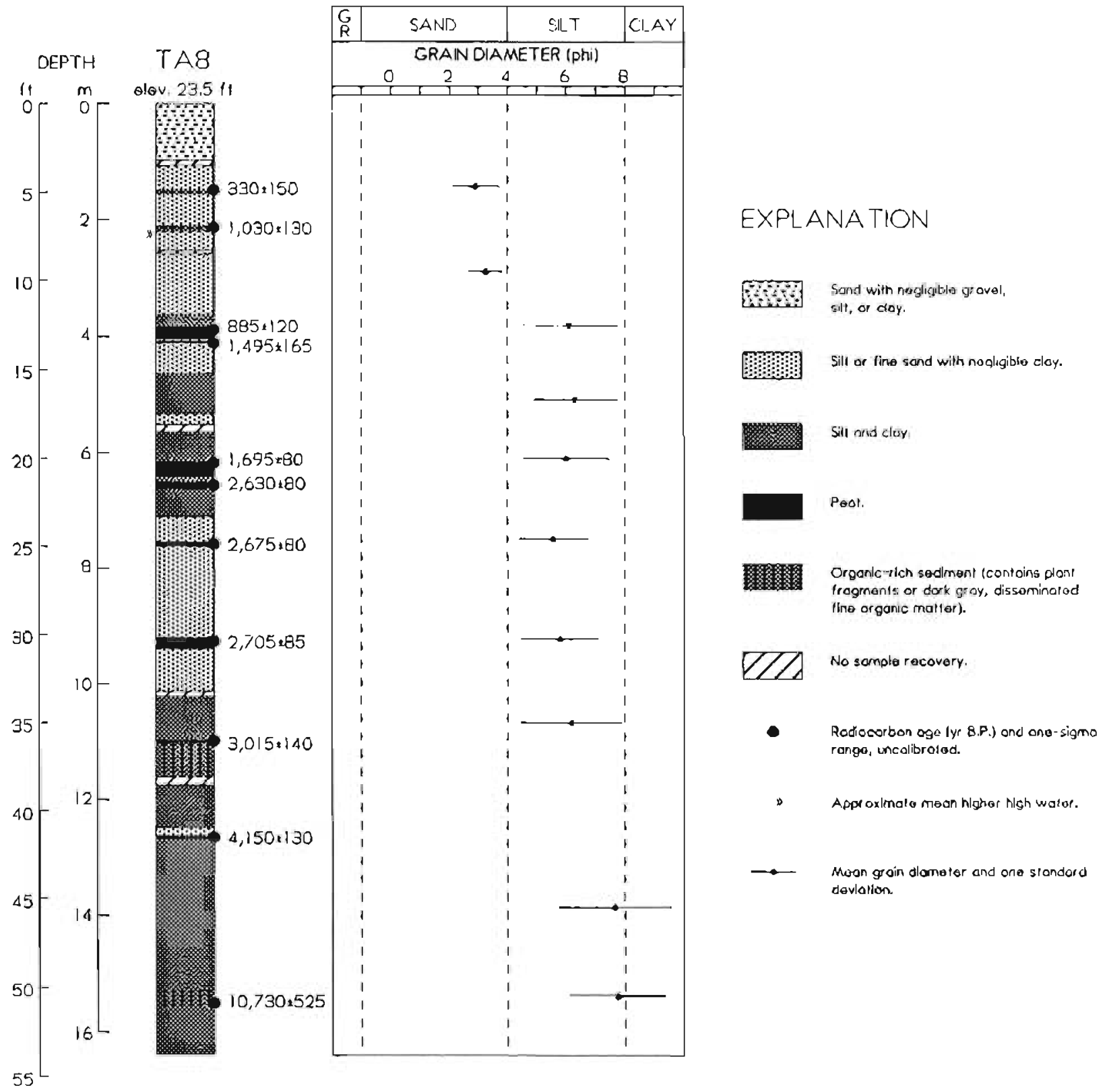

Figure B-2. Lithologic log and plot of grain-size analyses for borehole TA8 (Portage). 


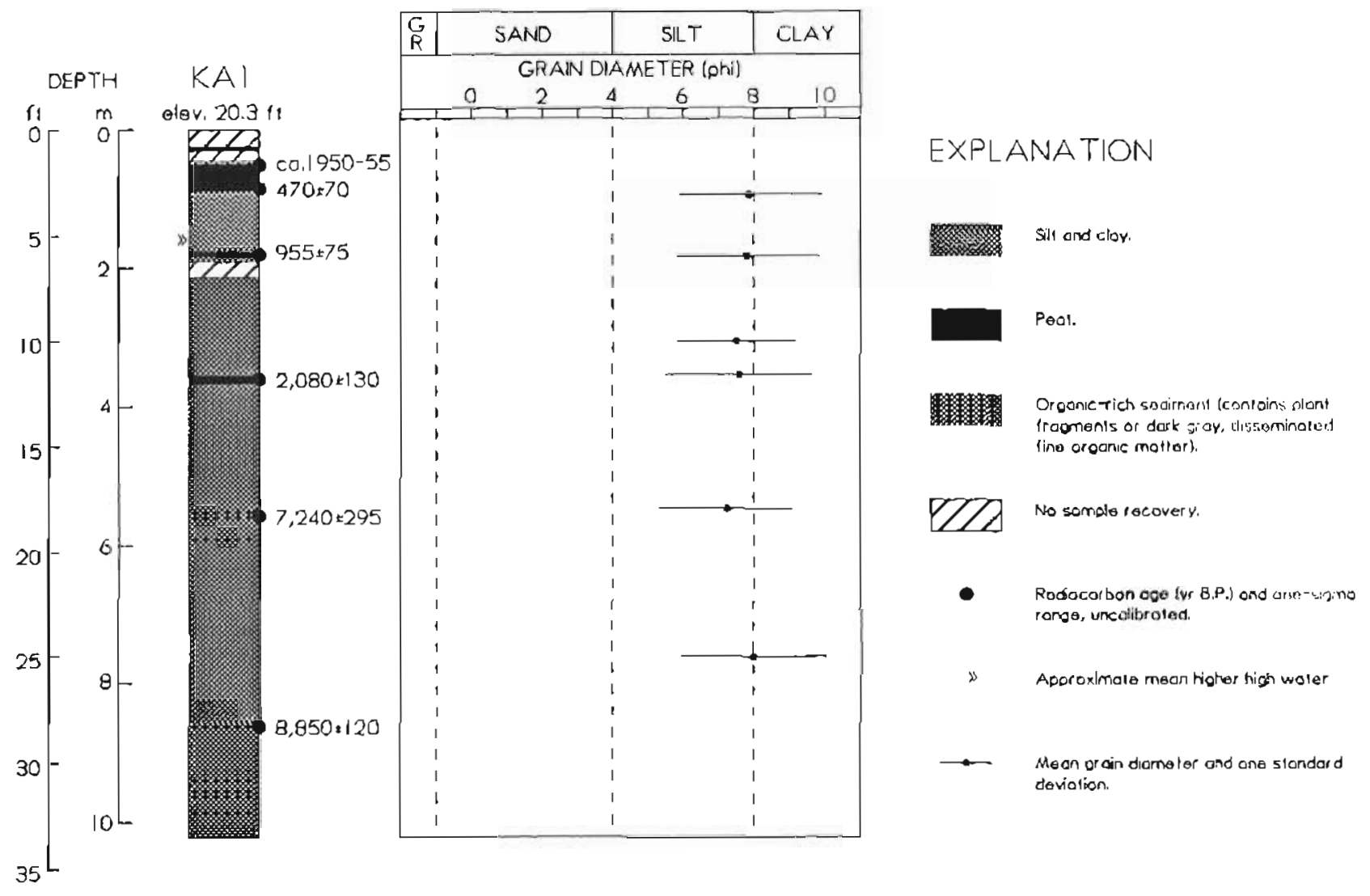

Figure B-3. Lithologic log and plot of grain-size (malyses for borehole KAl (Palmer Hay Flass). 

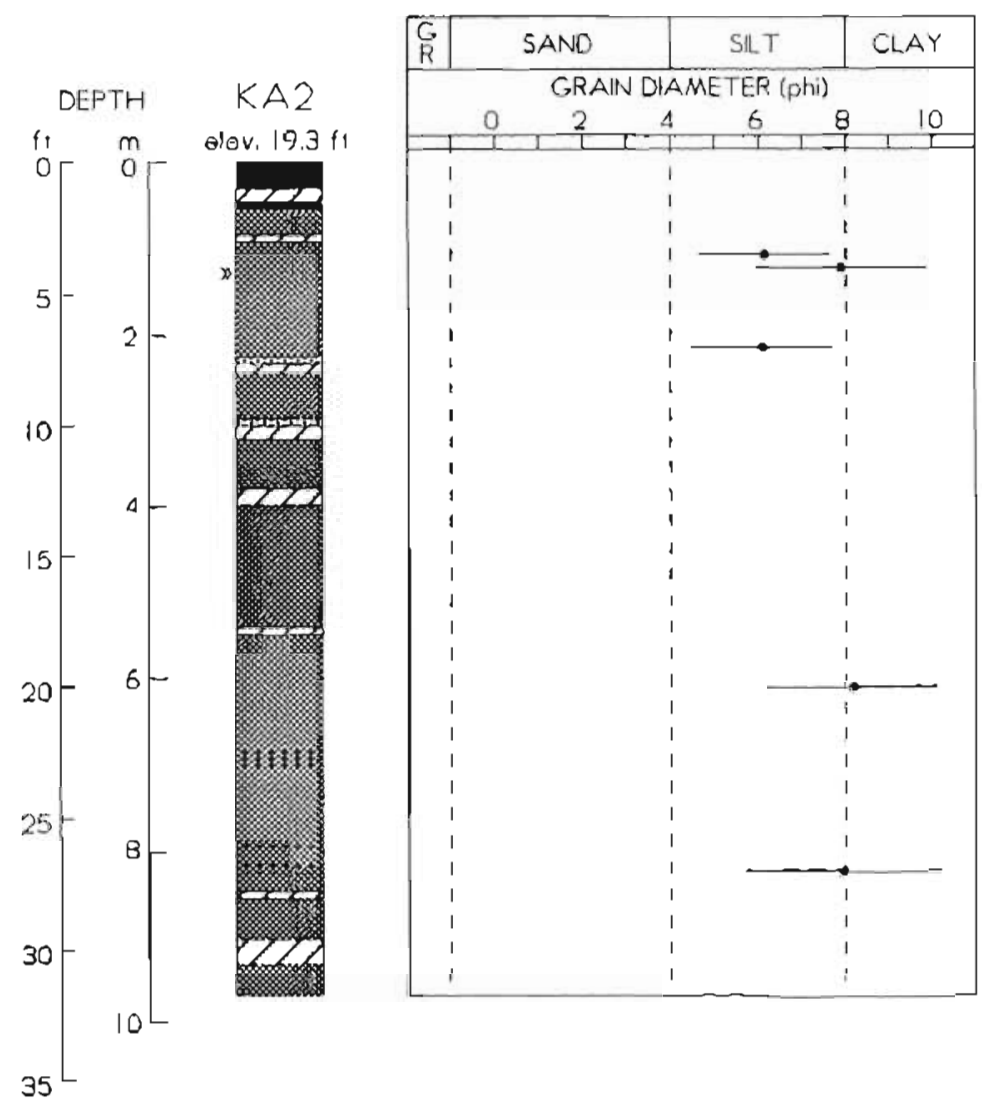

\section{EXPLANATION}

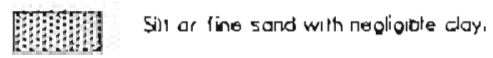

Sll ond elar.

Prot.

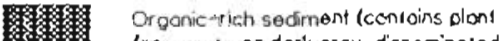
Irogments or dork groy, disseminaled line orgonic matterl.

17 No samole recovery.

* Approximate mean higher high wotes.

- Meon or oin giomelar and one slandara devialian

Figure B-4. Lirhologic log and plor of grain-size umalyses for borchole KA2 (Palmer Hay Flas.5).
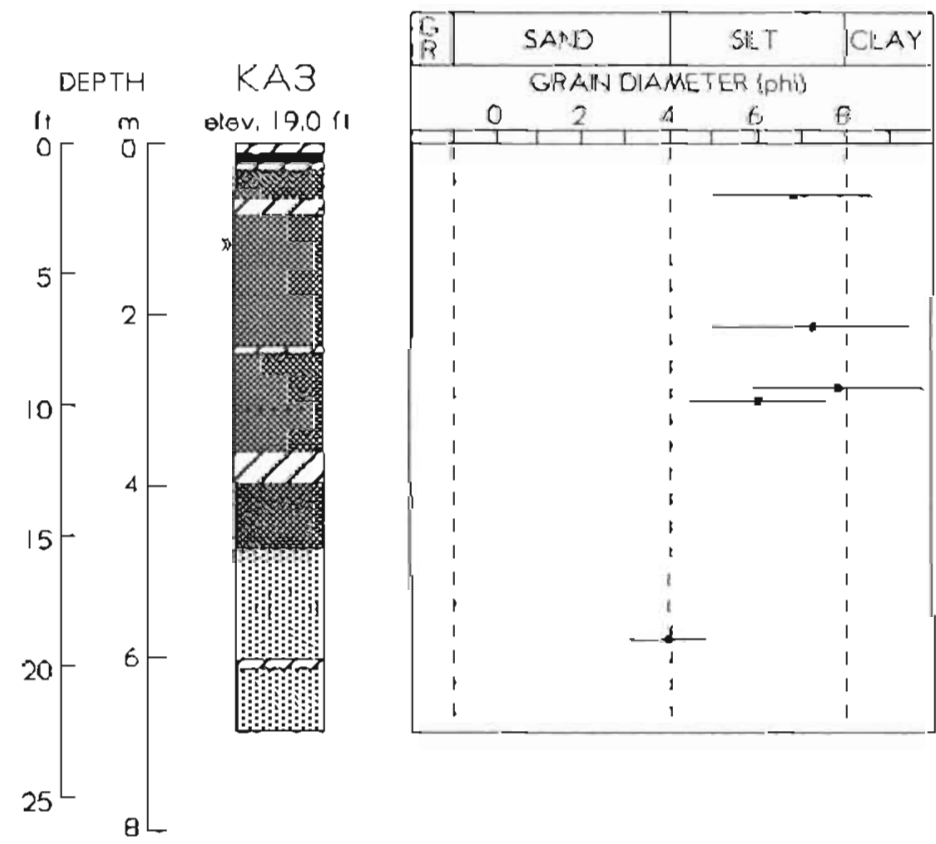

\section{EXPLANATION}
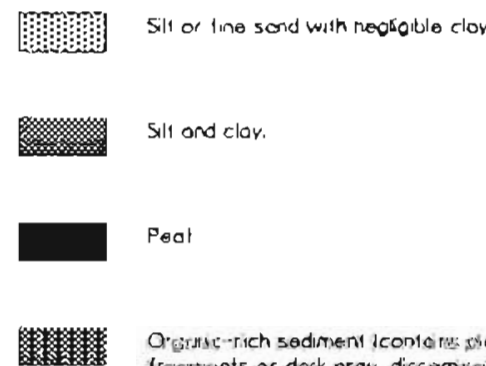

Orgarve-rich sadiment icontons plant Irogments or dork oroy, dissernitored tine oroonic maltar)

21 No sompla recovery.

* ADproximato moon Noher thigh woler

$\rightarrow \quad$ Menangrin dakneter ond one standaru devioton

Figure B-5. Lishologic log and plor of grnin-size analyses for burchole KA3 (Pulmes. Hoy' Flats). 


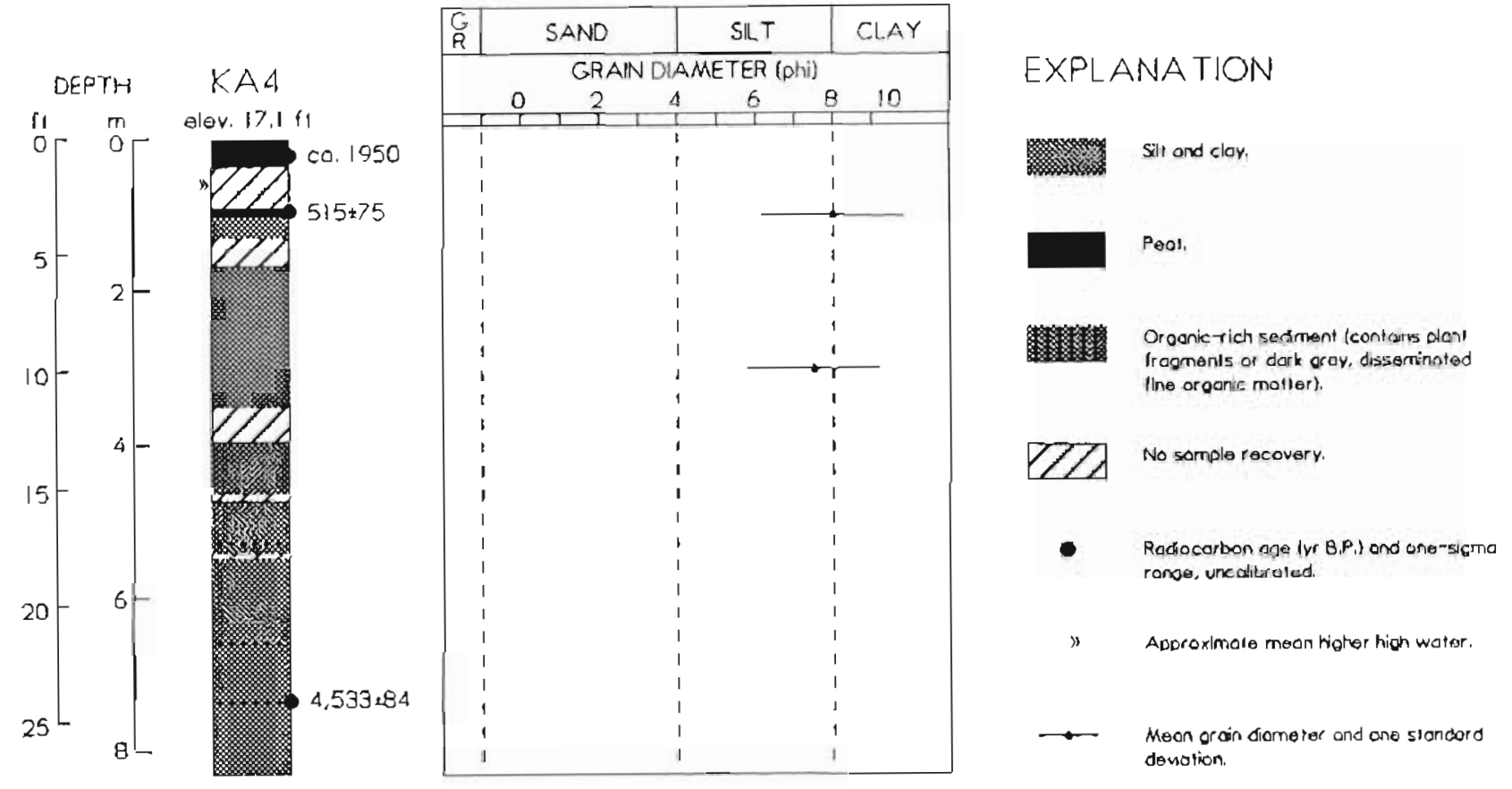

Figure B-6. Lithologic log and plot of grain-size analyses for borchole KA4 (Palmer Hay Flats).
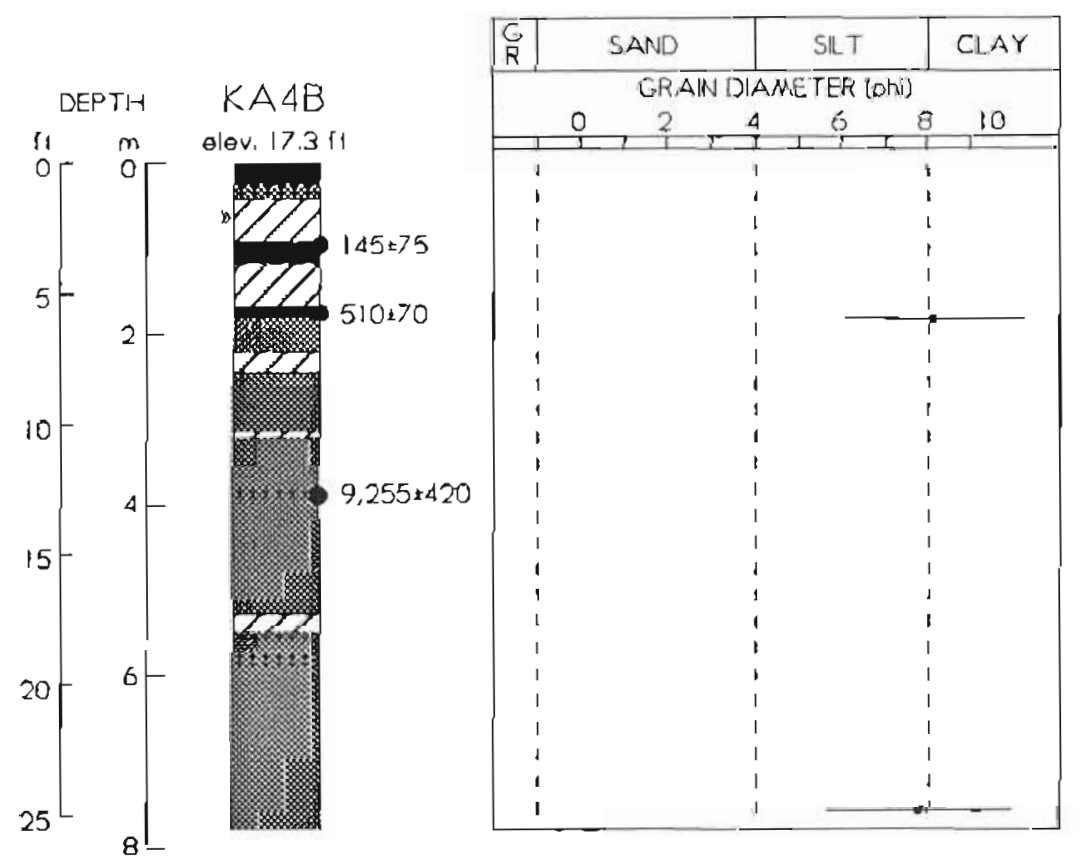

EXPLANATION

紧紧 Silt and cloy.

Piol.

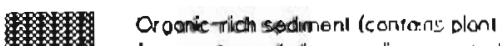
Irooments or dork gray, disselrinoted fine organic motter

17 no somole racovery.

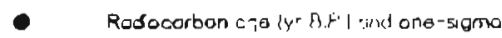
ranoe, uncolibroted.

- Aoproximale man trigher nion water

Me un oroin diameler and ana virirtard doviolion

Figure B-7. Lithologic log and plot of grain-size andyses for borchole KAAB (Palmer Hay Flars). 

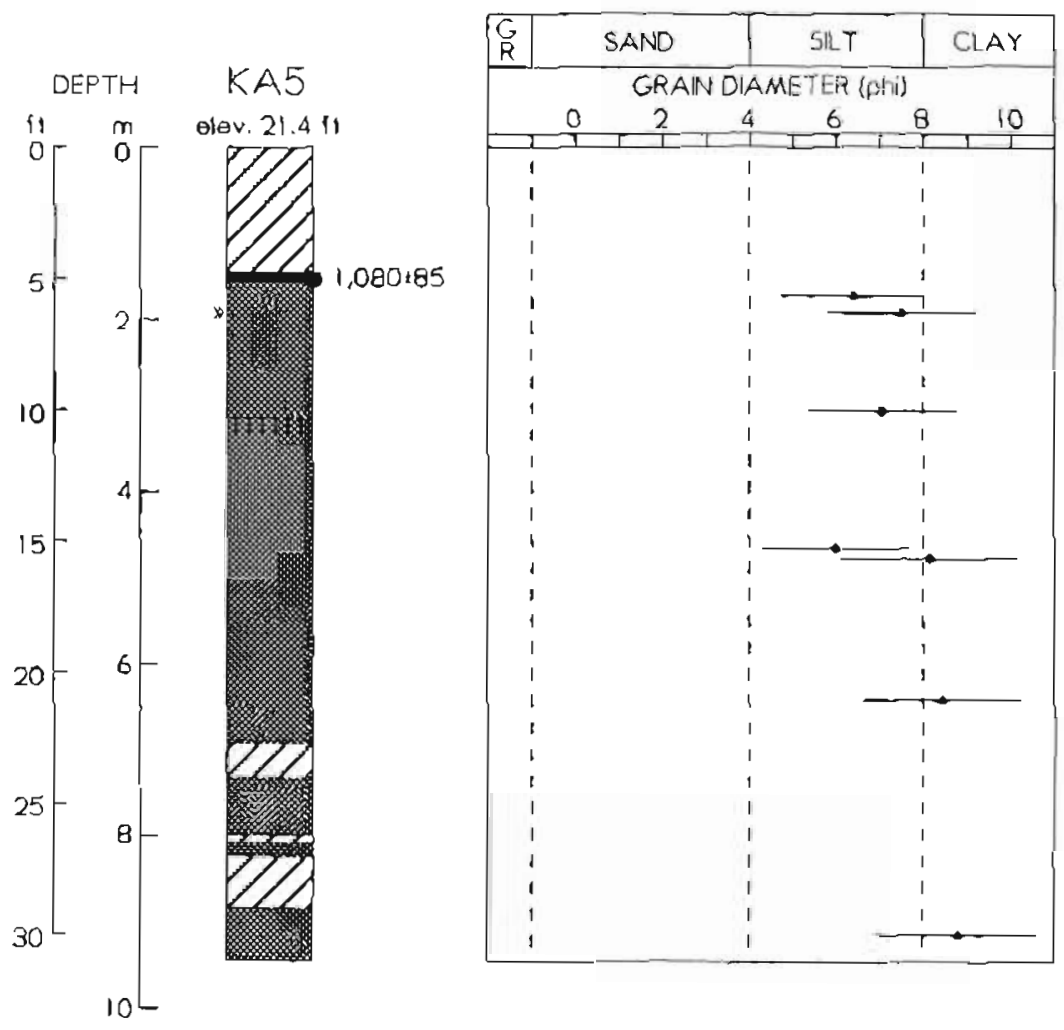

EXPLANATION

Silt ond ctar.

PeOI.

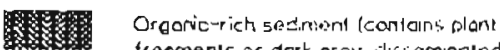
frogmenis or dark gray, tisseminaled fine oroan: rellerl.

PLA no somala recovery.

- Rodiocarbon oge lyr B.P l. ve-sgma ronos, uncolibroled.

A Aporoximato mean tigher high waler.

Moon grain diomales and one standord dovialion.

Figure B-8. Lishologic log and plar of grain-size analyses for borehole KAS (Palmer Hry Flars). 


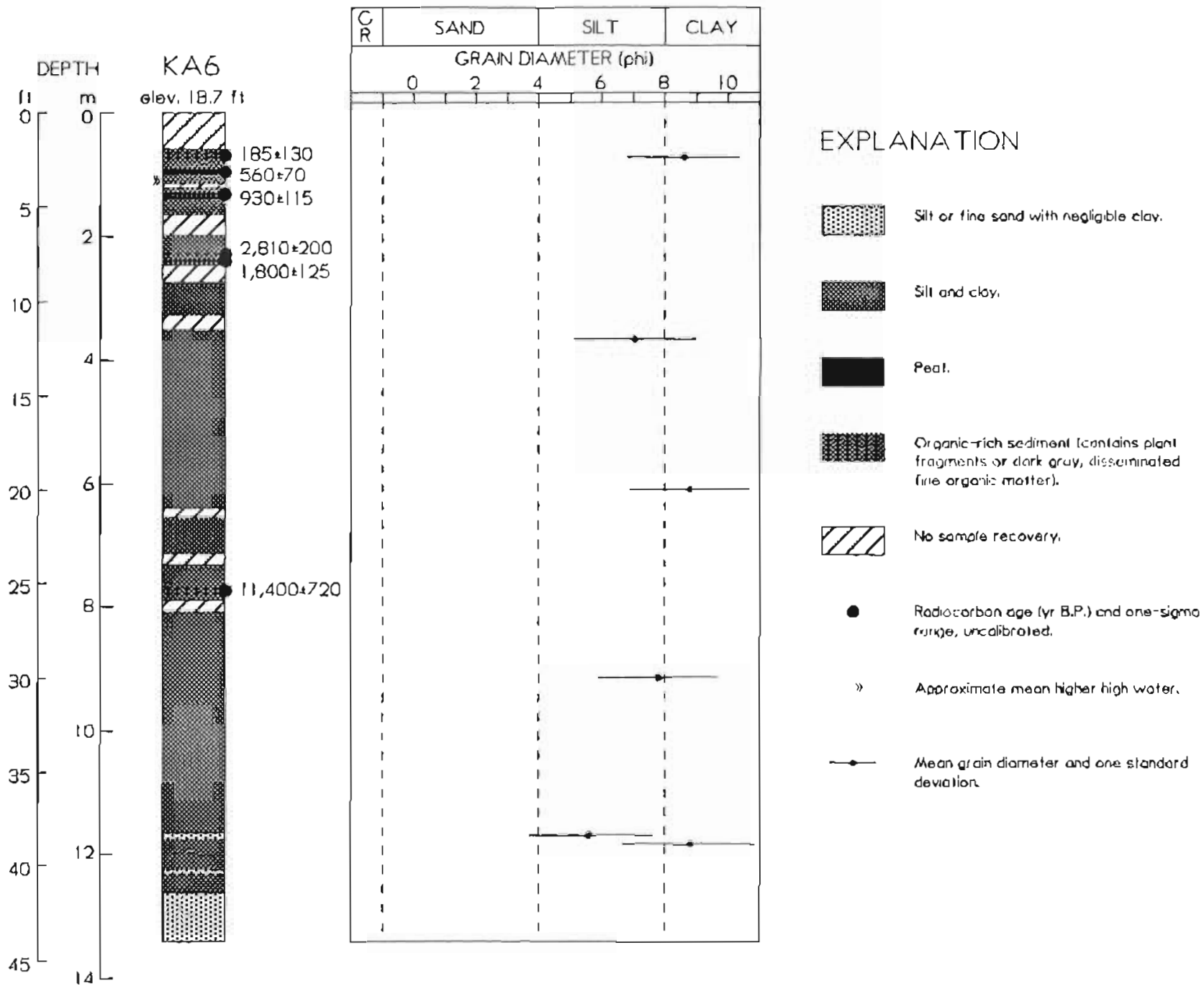

Figure B-9. Lithologic log and plor of grnin-size anmlyses for borehole KA6 (Pulmer Hay Flats). 